Prepared for the U.S. Department of Energy

under Contract DE-AC05-76RL01830

\title{
Evaluation of Soil Flushing for Application to the Deep Vadose Zone in the Hanford Central Plateau
}

\author{
MJ Truex \\ M Oostrom \\ ZF Zhang \\ $\mathrm{KC}$ Carroll \\ JA Schramke \\ TW Wietsma \\ GD Tartakovsky \\ KA Gordon \\ GV Last
}

November 2010

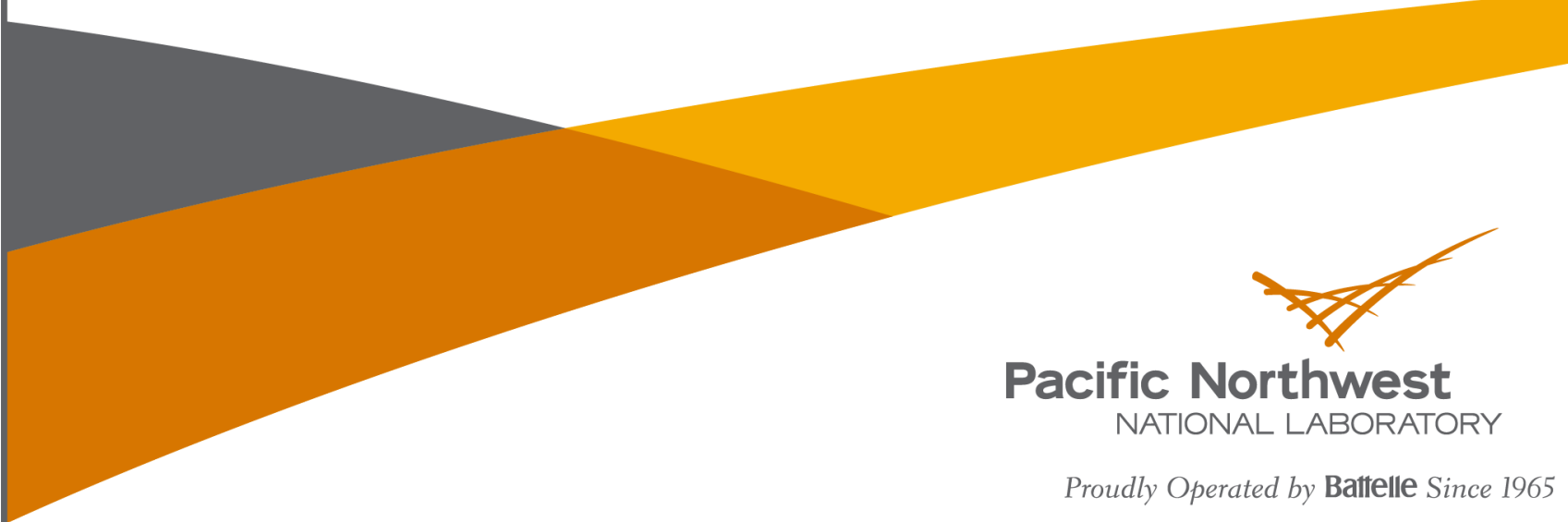




\title{
DISCLAIMER
}

This report was prepared as an account of work sponsored by an agency of the United States Government. Neither the United States Government nor any agency thereof, nor Battelle Memorial Institute, nor any of their employees, makes any warranty, express or implied, or assumes any legal liability or responsibility for the accuracy, completeness, or usefulness of any information, apparatus, product, or process disclosed, or represents that its use would not infringe privately owned rights. Reference herein to any specific commercial product, process, or service by trade name, trademark, manufacturer, or otherwise does not necessarily constitute or imply its endorsement, recommendation, or favoring by the United States Government or any agency thereof, or Battelle Memorial Institute. The views and opinions of authors expressed herein do not necessarily state or reflect those of the United States Government or any agency thereof.

\author{
PACIFIC NORTHWEST NATIONAL LABORATORY \\ operated by \\ BATTELLE \\ for the \\ UNITED STATES DEPARTMENT OF ENERGY \\ under Contract DE-AC05-76RL01830
}

\author{
Printed in the United States of America \\ Available to DOE and DOE contractors from the \\ Office of Scientific and Technical Information, \\ P.O. Box 62, Oak Ridge, TN 37831-0062; \\ ph: (865) 576-8401 \\ fax: $(865) 576-5728$ \\ email: reports@adonis.osti.gov
}

Available to the public from the National Technical Information Service

5301 Shawnee Rd., Alexandria, VA 22312

ph: (800) 553-NTIS (6847)

email: orders@ntis.gov $<$ http://www.ntis.gov/about/form.aspx $>$

Online ordering: http://www.ntis.gov

This document was printed on recycled paper. 


\title{
Evaluation of Soil Flushing for Application to the Deep Vadose Zone in the Hanford Central Plateau
}

\author{
MJ Truex \\ M Oostrom \\ ZF Zhang \\ KC Carroll \\ JA Schramke ${ }^{1}$ \\ TW Wietsma \\ GD Tartakovsky \\ KA Gordon \\ GV Last
}

November 2010

Prepared for

the U.S. Department of Energy

under Contract DE-AC05-76RL01830

Pacific Northwest National Laboratory

Richland, Washington 99352

\footnotetext{
${ }^{1}$ Enchemica, LLC
} 


\begin{abstract}
Soil flushing was included in the Deep Vadose Zone Treatability Test Plan for the Hanford Central Plateau (DOE-RL 2008 ${ }^{1}$ ) as a technology with the potential to remove contaminants from the vadose zone. Soil flushing operates through the addition of water, and if necessary an appropriate mobilizing agent, to mobilize contaminants and flush them from the vadose zone and into the groundwater where they are subsequently captured by a pump-and-treat system. There are uncertainties associated with applying soil flushing technology to contaminants in the deep vadose zone at the Hanford Central Plateau. The modeling and laboratory efforts reported herein are intended to provide a quantitative assessment of factors that impact water infiltration and contaminant flushing through the vadose zone and into the underlying groundwater. Once in the groundwater, capture of the contaminants would be necessary, but this aspect of implementing soil flushing was not evaluated in this effort. Soil flushing was evaluated primarily with respect to applications for technetium and uranium contaminants in the deep vadose zone of the Hanford Central Plateau.
\end{abstract}

${ }^{1}$ DOE-RL. 2008. Deep Vadose Zone Treatability Test Plan for the Hanford Central Plateau. DOE/RL-2007-56, Rev. 0, U.S. Department of Energy, Richland Operations Office, Richland, Washington. 



\section{Summary}

Soil flushing operates through addition of water, and if necessary an appropriate mobilizing agent, to mobilize contaminants and flush them from the vadose zone and into the groundwater where they are subsequently captured by a pump-and-treat system. As described in the Deep Vadose Zone Treatability Test Plan for the Hanford Central Plateau (DOE-RL 2008), investigation of these vadose zone processes through modeling and laboratory evaluation is needed as a first step in providing information for considering soil flushing in subsequent feasibility studies for the Hanford Site deep vadose zone.

Numerical modeling and laboratory flow-cell experiments were conducted to investigate the characteristics of water flow and solute transport through the vadose zone as a function of the imposed infiltration condition, subsurface properties, and properties of the leaching solution. Information on previous uranium leaching studies, infiltration studies at the Hanford Site data, and relevant uranium mining operations were compiled and evaluated with respect to how these approaches potentially apply to soil flushing in the Hanford Central Plateau.

There are uncertainties associated with applying soil flushing technology to contaminants in the deep vadose zone at the Hanford Central Plateau. Modeling and laboratory efforts reported herein are intended to provide a quantitative assessment of factors that impact water infiltration and contaminant flushing through the vadose zone and into the underlying groundwater. Once in the groundwater, capture of the contaminants would be necessary, but this aspect of implementing soil flushing was not evaluated in this effort. Soil flushing was evaluated primarily with respect to applications for technetium and uranium contaminants in the deep vadose zone of the Hanford Central Plateau.

Contaminants such as technetium do not interact significantly with the subsurface sediments and move with the infiltrating water. As such, soil flushing for technetium does not have limitations related to the chemistry of the flushing solution. Conversely, uranium interacts strongly with the subsurface sediments and both sorption and solubility-related processes can significantly slow its movement relative to the infiltrating water. Leaching solutions have been used for uranium extraction, but have limited applicability for sites with uranium contamination in the vadose zone at the Hanford Site. Many leaching solutions are for extracting chemically reduced uranium that is not prevalent at the Hanford Site; several use mild extraction solutions that would only address a portion of the uranium in the Site vadose zone; and the harshest extraction solution, acid dissolution, is not appropriate due to the acid neutralization capacity of the Site sediment and potential co-contaminant releases.

In addition to the leaching characteristics of the solution used for soil flushing, the processes of water infiltration and associated contaminant flushing need to be considered. Numerical modeling and laboratory flow-cell experiments investigated the characteristics of water flow and solute transport through the vadose zone as a function of the imposed infiltration condition, subsurface properties, and the physical properties of the leaching solution. Infiltrated water moves vertically in the vadose zone until a layer with a contrasting hydraulic properties is encountered. At these contacts, infiltrated water can be diverted laterally to an extent that depends on the hydraulic properties. Low permeability silt zones are of most significance for inducing lateral water flow in the Hanford Site vadose zone when they are surrounded by higher conductivity material. 
The impact of lateral water movement could be beneficial in terms of increasing the swept zone of the infiltration water. However, lateral flow could also increase the size of the capture zone needed in the groundwater and may cause water to be diverted toward areas with preferential downward flow that bypass contaminants. Lateral water flow could also increase the time and total water volume needed for soil flushing at a specific site. The impact of lateral water movement on contaminants depends on the location of the contaminants relative to the infiltration area and subsurface layering.

There are some uncertainties related to soil flushing that were not evaluated as part of this study. The impact of lateral heterogeneity, such as the presence of discontinuous silt lenses, was not quantified. Preferential pathways for water movement either caused by discontinuities in subsurface properties or features such as clastic dikes were not evaluated but should be considered for a specific site. Presence of preferential pathways could limit the effectiveness of soil flushing if contaminated zones are bypassed. The model also did not evaluate any slope to layers or inherent layer anisotropy that could impose lateral flow. These types of uncertainties may need to be considered in the design of a soil flushing system for a specific site, including design of a groundwater capture system in terms of the necessary capture zone. Limitations to infiltration at the surface may be another uncertainty to consider that was not included in the simulations. Presence of features that cause ponding of water rather than infiltration may limit soil flushing effectiveness, and surface infiltration rates for a specific site may need to be quantified as part of evaluating the applicability of soil flushing. Field testing in the 300-FF-5 and 100-NR-2 Operable Units at the Hanford Site is underway and should provide information relevant to surface infiltration rates that could be applied for soil flushing. 


\section{Acknowledgments}

The work was funded by CH2M HILL Plateau Remediation Company as part of Deep Vadose Zone Treatability Test activities conducted for the Hanford Central Plateau. 



\section{Acronyms and Abbreviations}

\begin{tabular}{|c|c|}
\hline $\mathrm{Bf}$ & backfill \\
\hline Bf_SW & backfill Site-wide \\
\hline BWTF & Burial Waste Treatment Facility \\
\hline CBD & citrate-bicarbonate-dithionite \\
\hline $\mathrm{CCU}$ & Cold Creek unit \\
\hline CCUc & Cold Creek unit - caliche \\
\hline CCUg & Cold Creek unit - gravel-dominated \\
\hline CCUz & Cold Creek unit - silt-dominated \\
\hline CRBG & Columbia River Basalt Group \\
\hline $\mathrm{dr}$ & radial spacing \\
\hline $\mathrm{dz}$ & vertical spacing \\
\hline H1 & Hanford formation unit 1 \\
\hline $\mathrm{H} 2$ & Hanford formation unit 2 \\
\hline H3 & Hanford formation unit 3 \\
\hline Hes & Hanford formation, coarse sand \\
\hline Hes_BC & Hanford formation, coarse sand - BC Crib Area \\
\hline Hfs & Hanford formation, fine sand \\
\hline Hfs_BC & Hanford formation fine sand - BC Crib Area \\
\hline Hg_SW & Hanford formation, sandy gravel Site-wide \\
\hline Hss & Hanford formation, silty sand \\
\hline ISR & in-situ recovery \\
\hline ppm & parts per million \\
\hline PUREX & Plutonium Uranium Extraction Plant \\
\hline $\operatorname{Rg}$ & Ringold Formation, gravel dominated \\
\hline Rtf & Ringold Formation, member of Taylor Flat \\
\hline Rwi & Ringold Formation, member of Wooded Island \\
\hline STOMP & Subsurface Transport Over Multiple Phases \\
\hline TVD & Total Variation Diminishing \\
\hline WS & Warden Silt \\
\hline
\end{tabular}





\section{Contents}

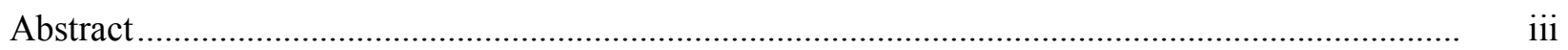

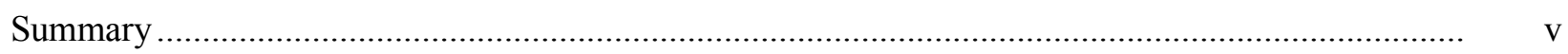

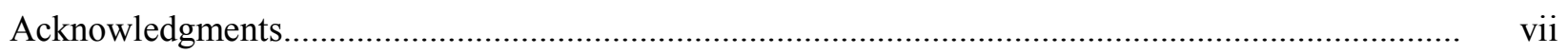

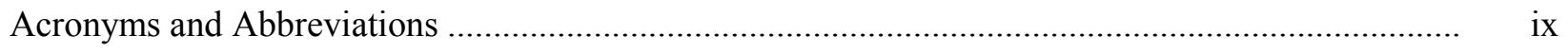

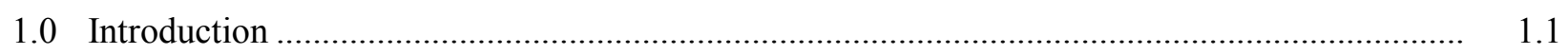

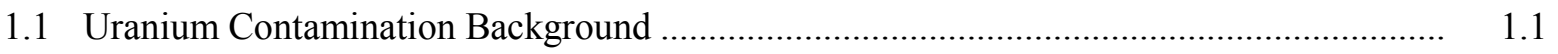

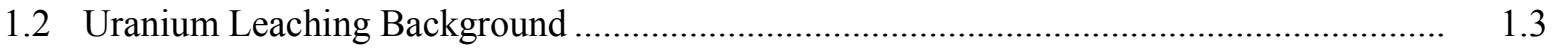

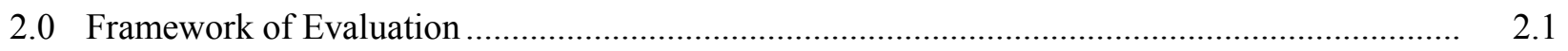

3.0 Modeling Study of Water Infiltration and Contaminant Flushing ......................................... 3.1

3.1 Geology and Hydraulic Properties ............................................................................. 3.1

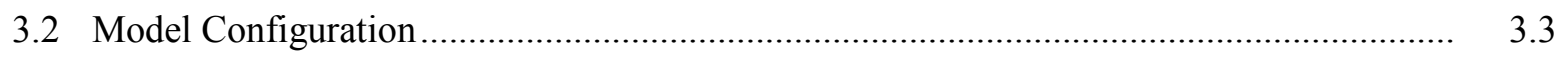

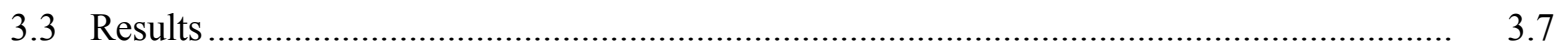

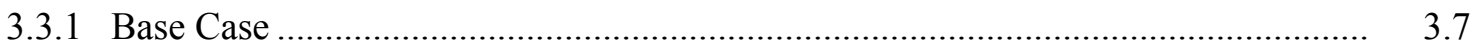

3.3.2 Impacts of Infiltration Rate ........................................................................ 3.9

3.3.3 Impacts of Conductivity and Layer Thickness .................................................. 3.10

3.3.4 Impact of Fluid Properties ........................................................................... 3.18

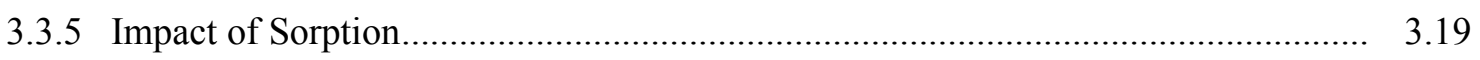

4.0 Laboratory Study of Water Infiltration and Contaminant Flushing ....................................... 4.1

4.1 Laboratory Experimental Approach ................................................................................ 4.1

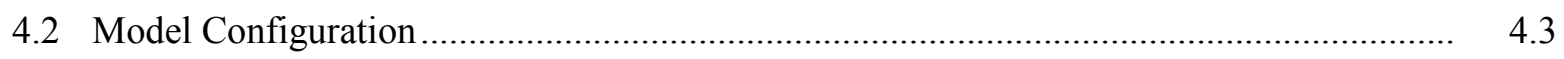

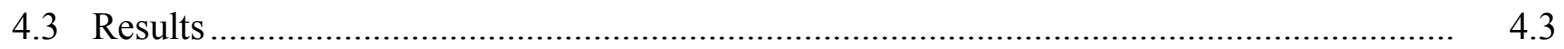

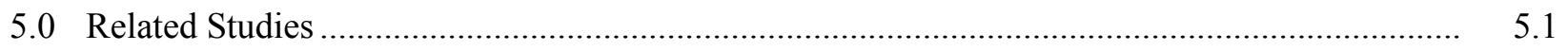

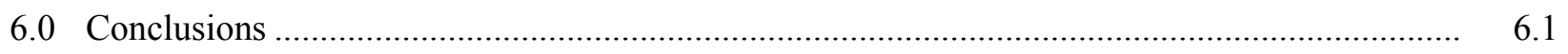

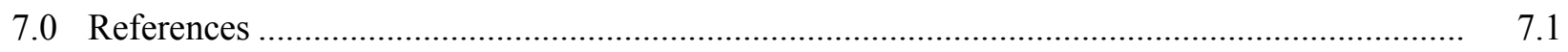




\section{Figures}

3.1 Generalized lithostratigraphy illustrating the mean thicknesses for the $200 \mathrm{West}$

Area and the southern half of the 200 East Area.

3.2 Impacts of grid spacing on the cumulative mass of a conservative contaminant entering into the groundwater

3.3 Initial distribution of saturation and aqueous contaminant concentrations for the 200 West Area.

3.4 Initial distribution of saturation and aqueous contaminant concentrations for the 200 East Area

3.5 Water saturation distribution for the 200 West Area at $0.1,0.5,1.0$, and $2.0 \mathrm{yr}$ with an infiltration rate of $52 \mathrm{~cm} / \mathrm{d}$.

3.6 Distribution of the aqueous concentration in the 200 West Area for the conservative contaminant for at $0.1,0.5,1.0$, and $2.0 \mathrm{yr}$ with an infiltration rate of $52 \mathrm{~cm} / \mathrm{d}$

3.7 Water saturation distribution for the 200 East Area at 0.1, 0.5, 1.0, and $2.0 \mathrm{yr}$ with an infiltration rate of $52 \mathrm{~cm} / \mathrm{d}$

3.8 Distribution of the aqueous concentration in the 200 East Area for the conservative contaminant for at $0.1,0.5,1.0$, and $2.0 \mathrm{yr}$ with an infiltration rate of $52 \mathrm{~cm} / \mathrm{d}$

3.9 Simulated soil water saturation for the 200 West Area at 2 yrs for different infiltration rates

3.10 Simulated aqueous concentration of the conservative contaminant at different infiltration rates in the 200 West Area

3.11 Simulated soil water saturation for the 200 East Area at 2 yrs for different infiltration rates

3.12 Simulated aqueous concentration of the conservative contaminant at different infiltration rates in the 200 East Area.

3.13 Simulated aqueous saturation at 2 yrs in the 200 West Area

3.14 Percentage of cumulative aqueous volume across a vertical plane at radius $r=50 \mathrm{~m}$ for the total injected volume after 2 yrs in the 200 West Area

3.15 Simulated aqueous concentration of the conservative contaminant at $2 \mathrm{yrs}$ in the 200 West Area.

3.16 Simulated aqueous saturation at 2 yrs in the 200 East Area

3.17 Percentage of cumulative aqueous volume across a vertical plane at radius $r=50 \mathrm{~m}$ for the total injected volume after 2 yrs for the 200 East Area

3.18 Simulated aqueous concentration of the conservative contaminant at $2 \mathrm{yrs}$ in the 200 East Area

3.19 Saturation distributions for variations in flushing fluid density and viscosity.....

3.20 Cumulative aqueous volume into the groundwater vertically beneath the infiltration area

3.21 The aqueous contaminant concentration in the 200 West Area at $1.2 \mathrm{yr}$ for the base case configuration of simulation set I

4.1 Schematic for Experiment I with the initially contaminated zone in red

4.2 Schematic of Experiment II with the initially contaminated zone in red 
4.3 Steady-state aqueous saturation distribution for Experiment I based on dual-energy gamma radiation measurements.

4.4 Steady-state aqueous saturation distribution for Experiment II based on dual-energy gamma radiation measurements.

4.5 Experimental and numerical effluent $\mathrm{Br}$ breakthrough curves for Experiment I and Experiment II

4.6 Simulated $\mathrm{Br}$ effluent breakthrough curves for the base case and Simulations 1-8 for the homogeneous configuration.

4.7 Simulated $\mathrm{Br}$ concentration distribution after 1 hour of flushing for Experiment I .................. 4.6

4.8 Simulated $\mathrm{Br}$ concentration distribution after 3 hours of flushing for Experiment I ................ 4.7

4.9 Simulated Br concentration distribution after 6 hours of flushing for Experiment I ................ 4.7

4.10 Simulated $\mathrm{Br}$ concentration distribution after 1 hour of flushing for Experiment II................. 4.8

4.11 Simulated $\mathrm{Br}$ concentration distribution after 3 hours of flushing for Experiment II ................ 4.8

4.12 Simulated $\mathrm{Br}$ concentration distribution after 6 hours of flushing for Experiment II ............... 4.9

4.13 Bromide concentration distribution after 10 hours of flushing for Experiment II .................. 4.9

\section{Tables}

1.1 Representative concentrations in uranium alkaline ISR lixiviants ........................................ 1.4

1.2 Lixiviant concentrations reported for acid ISR operations .............................................. 1.8

1.3 Summary of extraction processes and potential for field application at the Hanford

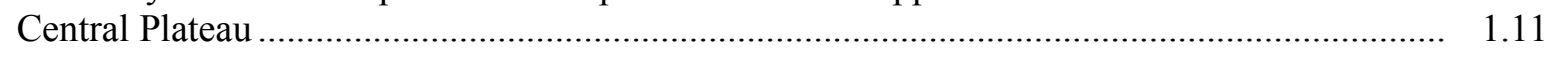

3.1 Representative hydraulic properties of the 200 West Area .................................................... 3.3

3.2 Representative hydraulic properties of the 200 East Area .................................................... 3.3

4.1 Overview of porous medium and hydraulic property values for the Warden Silt and Burial Waste Treatment Facility sediment...

4.2 Overview of hydraulic parameter values for the base case and sensitivity simulations 


\subsection{Introduction}

Soil flushing operates through addition of water, and if necessary an appropriate mobilizing agent, to mobilize contaminants and flush them from the vadose zone into the groundwater where they are subsequently captured by a pump-and-treat system (CHG 2007). The ability to contact targeted contamination in the vadose zone with the leaching solution and have the leaching solution move contaminants into the groundwater are key factors for successful application of soil flushing for the deep vadose zone in the Hanford Central Plateau. As described in the Deep Vadose Zone Treatability Test Plan for the Hanford Central Plateau (DOE-RL 2008), investigation of these vadose zone processes through modeling and laboratory evaluation is needed as a first step in providing information for considering soil flushing in subsequent feasibility studies for the Hanford Site deep vadose zone.

Soil flushing was evaluated primarily with respect to applications for technetium and uranium contaminants in the deep vadose zone of the Hanford Central Plateau because these contaminants are the focus of the deep vadose zone treatability test plan (DOE-RL 2008). Technetium does not interact significantly with subsurface sediments and moves with the infiltrating water. Thus, soil flushing for technetium does not have limitations related to the chemistry of the flushing solution. Conversely, uranium interacts strongly with the subsurface sediments and both sorption and solubility-related processes can significantly slow its movement relative to the infiltrating water. Thus, the evaluation of soil flushing also considered the impact of contaminant sorption and potential uranium leaching approaches.

Numerical modeling and laboratory flow-cell experiments were conducted to investigate the characteristics of water flow and solute transport through the vadose zone as a function of the imposed infiltration condition, subsurface properties, and leaching solution properties. Information on previous uranium leaching studies, infiltration studies at the Hanford Site, and relevant uranium mining operations were compiled and evaluated with respect to how these approaches potentially apply to soil flushing in the Hanford Central Plateau.

Sections 1.1 and 1.2 provide information about uranium chemistry and leaching approaches as context for evaluating soil flushing for uranium. Technetium background is not provided because it is assumed to be present in the mobile pertechnetate anion form in the Hanford Site vadose zone. Section 2.0 describes the framework for the soil flushing evaluation. Modeling and laboratory studies are reported in Sections 3.0 and 4.0, respectively. Section 5.0 summarizes infiltration studies at the Hanford Site that will provide information useful for consideration of the soil flushing technology. Conclusions from this evaluation of soil flushing are presented in Section 6.0.

\subsection{Uranium Contamination Background}

Unconsolidated sediments, between 30 and $122 \mathrm{~m}$ thick, overlie the Columbia River Basalt Group lava flows at the 200 Area (Zachara et al. 2007a). A laterally extensive, low permeability formation called the CCU, or Cold Creek Unit, is a mixture of caliche (or calcrete), a fine- to coarse-grained, calcium-carbonate cemented paleosol, and a cohesive, compact, massive to laminated, and stratified finegrained sand and silt (e.g., sandy mud). Above and below this unit are the higher-permeability units called the Hanford and Ringold Formations, respectively. The Hanford formation contains a sequence of interbedded sand and mud, coarse to medium sand, and sandy gravel (Oostrom et al. 2008). The Ringold 
Formation is a sedimentary sequence of fluvial-lacustrine clay, silt, sand, and granule to cobble gravel deposited by the ancestral Columbia River, and the water table is located within the Ringold Formation at the 200 Area (Zachara et al. 2007a).

The Hanford and Ringold Formation deposits have similar mineralogy (Zachara et al. 2007a). The gravels are mainly basalt, the sands are a split between basalt and granite, and the silt is dominated by quartz, feldspars, and micas. The clay fraction is dominated by smectitic phyllosilicates, ferroan chlorite, and biotite/muscovite micas with some serpentine minerals. Fe(III) oxides are prevalent, whereas $\mathrm{Mn}(\mathrm{III} / \mathrm{IV})$ oxides are highly variable. Both detrital and pedogenic calcite are prevalent throughout, which buffers soil and groundwater. Cation-exchange capacities are generally correlated to the silt and clay fraction (Ward et al. 2006).

The discharged waste composition was highly variable. Each processing scheme (including bismuth phosphate, Reduction-Oxidation Plant [REDOX], and the Plutonium Uranium Extraction Plant [PUREX]) generated several wastes of variable composition (Zachara et al. 2007a). The composition from the largest tank leaks (SX-108, BX-102, and T-106) varied from alkaline to caustic with high ionic strengths and temperatures, and they contained a variety of metals and radionuclides. The discharged waste was highly reactive with the sediment as infiltration occurred, which led to a geochemically heterogeneous uranium retention and phase distribution (Zachara et al. 2007a, 2007b; McKinley et al. 2007; Um et al. 2009). Sediment samples collected near BX-102 tanks have uranium-silicate precipitates including boltwoodite and uranophane (Um et al. 2009). McKinley et al. (2007) showed that the boltwoodite occurred through secondary mineral formation within microfractures, which was likely attributed to the alkaline and silica-poor composition of the tank leaks.

Although uranium is generally found as $\mathrm{U}(\mathrm{VI})$, its retention and association with the sediment changes with depth (Um et al. 2009). The shallow sediments (15-16 m bgs) contained uranium precipitates including boltwoodite and uranophane $(665 \mu \mathrm{g} / \mathrm{g})$, which generally exhibit lower water solubility with respect to uranium than the deeper sediments. The intermediate depth sediments (20-25 m bgs) contained uranium as mineral surface precipitates and adsorbed phases (14-32 $\mu \mathrm{g} \mathrm{g} / \mathrm{g}$ ), and Zachara et al. (2007a) showed that the uranium was retained through adsorption to mineral surfaces or incorporated into calcite surface precipitates. The deepest sediments ( $>28 \mathrm{~m} \mathrm{bgs})$ contained background uranium $(<5 \mu \mathrm{g} \mathrm{g} / \mathrm{g}$ ) with no evidence of tank waste migration (Um et al. 2009). These observations indicate that the distribution, composition, reactivity, and mobility of uranium within the 200 Area sediments are heterogeneous.

Recently, Szecsody et al. (2010a, 2010b) applied the series of six sequential sediment extractions listed below as an operational means to quantify how uranium is distributed within a sediment sample. These extractions progress through increasingly harsh reagents. In these tests, only a portion of the uranium in sediment samples from the Hanford Central Plateau was extracted by the first three extraction solutions. These data suggest that some of the uranium in contaminated Hanford Site sediments is currently resistant to extraction by mild extraction solutions. The extraction solutions from Szecsody et al. (2010a, 2010b) include the following elements:

1. Simulated groundwater extraction (e.g., pore-water extraction)

2. $1 \mathrm{M} \mathrm{Mg-nitrate} \mathrm{extraction} \mathrm{(extraction} \mathrm{of} \mathrm{adsorbed} \mathrm{uranium)}$ 
3. Acetate extraction solution at $\mathrm{pH} 5$ for 1 hour (mild dissolution of surface precipitates such as carbonates)

4. Acetic acid extraction solution at $\mathrm{pH} 2.3$ for 1 week (dissolution of surface precipitates such as carbonates and potentially other compounds)

5. $0.1 \mathrm{M}$ oxalic acid and $0.1 \mathrm{M}$ ammonium oxalate solution for 4 hours (moderate mineral dissolution [e.g., amorphous materials])

6. $8 \mathrm{M}$ nitric acid at $95^{\circ} \mathrm{C}$ for 2 hours (significant mineral dissolution).

Uranium waste discharges at the Hanford Site are mixed with other radioactive, inorganic, and organic contaminants. Review of leaching solutions was focused on uranium. However, the impact of leaching solutions on co-contaminants would need to be considered for application of soil flushing to waste sites in the Hanford Central Plateau.

\subsection{Uranium Leaching Background}

Several types of leaching solutions have been studied and applied to uranium leaching. For example, application of acids for the enhanced dissolution of uranium has been conducted since the inception of uranium mining (Bartlett 1998), and many selective dissolution techniques have been developed for engineering, soil science, mineralogical, and geochemical investigations (e.g., Jackson 1985; Jackson et al. 1986; Beckett 1989). Results of a literature review of previous efforts are summarized below.

In-situ recovery (ISR) is the dominant uranium recovery process used in the United States, with about 12 currently operating facilities (NRC 2010). There are a number of similarities between uranium ISR processes and the use of soil flushing to remove uranium from contaminated sediments, but some significant differences also exist. One potentially significant difference is the oxidation state of uranium in the targeted solid phase. The solid phase and adsorbed uranium in the 200 Area contaminated soil is predominantly in the oxidized form uranium(VI) (Szecsody et al. 2010a, 2010b), whereas uranium in natural deposits that are mined using ISR is typically present as uranium(IV), which is the reduced form. In addition, most ISR-targeted uranium deposits are located below the water table, in contrast to the vadose zone location of the uranium contamination in the 200 Area soils. Natural uranium deposits are also likely to have different associated co-contaminants than the 200 Area soils. The constituents of potential concern usually associated with natural uranium deposits include arsenic, iron, manganese, molybdenum, radium, selenium and vanadium (NRC 2009).

The two principal ISR methods are alkaline (carbonate) leaching and sulfuric acid leaching (Taylor et al. 2004; NRC 2009). Acid-based leaching has not been used commercially in the United States, although it has been used for small-scale research and development operations (NRC 2009). Acid leaching of uranium ore deposits containing greater than about $2 \%$ carbonate is not economically feasible, and ISR at a site with significant carbonate would require use of the alkaline leach process (Taylor et al. 2004). The length of time an ISR system is operated in a well field is highly variable, depending on uranium recovery efficiency and economic considerations, particularly uranium prices. Typically, an ISR well field is operated for several years before active uranium recovery is completed and groundwater restoration begins (e.g., Power Resources 1999; Crow Butte Resources 2000; Cogema Mining 2004). 
Carbonate Solutions: Carbonate (alkaline) leaching has been used for in-situ uranium mining since the 1950s (ORNL 1993). Carbonate can be added to the leaching solution or lixiviant as sodium carbonate, sodium bicarbonate, or dissolved carbon dioxide. Because uranium is typically present in the deposit as reduced uranium(IV), either dissolved oxygen or hydrogen peroxide are also added to the lixiviant to oxidize uranium to the +VI oxidation state, thereby increasing uranium mobilization. Inclusion of an oxidant in the lixiviant can result in enhanced mobilization of other metals, such as selenium, during uranium ISR. A fairly wide range of constituent concentrations can be achieved in ISR lixiviants (Table 1.1).

Table 1.1. Representative concentrations in uranium alkaline ISR lixiviants

\begin{tabular}{|c|c|c|c|c|c|}
\hline Constituent & $\begin{array}{c}\text { Wyoming } \\
\text { Site }^{(a)}\end{array}$ & Texas Site $^{(a)}$ & $\begin{array}{c}\text { Kingsville } \\
\text { Dome Site, } \\
\text { Texas }^{(b)}\end{array}$ & $\begin{array}{c}\text { Typical } \\
\text { Chemistry }^{(c)}\end{array}$ & $\begin{array}{c}\text { Typical Lixiviant } \\
\text { Chemistry } \\
\text { Range }^{(\mathrm{d})}\end{array}$ \\
\hline Calcium & 138 & 273 & 560 & $100-350$ & $\leq 20-500$ \\
\hline Magnesium & 42 & 82 & 92 & $10-50$ & $\leq 3-100$ \\
\hline Sodium & 365 & 1,007 & 800 & $500-1,600$ & $\leq 400-6,000$ \\
\hline Potassium & 12 & 26.5 & 31 & $25-250$ & $\leq 15-300$ \\
\hline Carbonate & NR & NR & NR & $0-500$ & $\leq 0.5-2,500$ \\
\hline Bicarbonate & NR & 579 & 619 & $800-1,500$ & $\leq 400-5,000$ \\
\hline Chloride & 140 & 1,009 & 919 & $250-1,800$ & $\leq 200-5,000$ \\
\hline Sulfate & 229 & 1,181 & 1,660 & $100-1,200$ & $\leq 400-5,000$ \\
\hline Silica & 24.6 & NR & 23.5 & $25-50$ & NR \\
\hline pH (standard units) & 6.7 & 6.71 & 6.82 & $7-9$ & $\leq 6.5-10.5$ \\
\hline $\begin{array}{l}\text { Total dissolved } \\
\text { solids }\end{array}$ & 1,713 & 4,186 & 4,640 & $1,500-5,500$ & $\leq 1,650-12,000$ \\
\hline $\begin{array}{l}\text { Alkalinity (as } \\
\mathrm{CaCO}_{3} \text { ) }\end{array}$ & 620 & NR & 507 & NR & NR \\
\hline Arsenic & NR & NR & 0.016 & NR & NR \\
\hline Iron & NR & NR & 0.02 & NR & NR \\
\hline Manganese & NR & NR & 1.7 & NR & NR \\
\hline Molybdenum & NR & NR & 32 & NR & NR \\
\hline $\begin{array}{l}\text { Radium-226 } \\
(\mathrm{pCi} / \mathrm{L})\end{array}$ & NR & NR & 293 & 500 & NR \\
\hline Selenium & NR & NR & 0.104 & NR & NR \\
\hline Uranium & 18.2 & 28.6 & 29.0 & $50-250$ & $\leq 0.008-424$ \\
\hline Vanadium & NR & NR & $<0.01$ & NR & $\leq 0.006-56$ \\
\hline $\begin{array}{l}\text { All units are mg/L u } \\
\text { NR = Not reported. } \\
\text { (a) Deutsch et al. ( } \\
\text { (b) Schramke et al. } \\
\text { (c) Pelizza (2008). } \\
\text { (d) NRC (2009). }\end{array}$ & $\begin{array}{l}\text { Ss otherwis } \\
\text { 5). } \\
09) \text {. }\end{array}$ & ted. & & & \\
\hline
\end{tabular}


Carbon dioxide, sodium carbonate, and sodium bicarbonate are typically used as uranium complexing agents in the lixiviant at ISR operations in the United States. Ammonium carbonate was used at some ISR sites in the past because of concerns that sodium could decrease permeability due to swelling clays. However, ammonium carbonate is no longer in use at ISR sites in the United States because ammoniumcarbonate lixiviants caused problems by desorbing slowly from clays during post-ISR aquifer restoration, increasing the quantities of groundwater that must be processed (NRC 2009). At sites where sodium may affect permeability, carbon dioxide gas is typically used to provide carbonate in the lixiviant.

Uranium forms strong complexes with carbonate in alkaline solutions, such as $\left(\mathrm{UO}_{2}\right)_{2} \mathrm{CO}_{3}(\mathrm{OH})_{3}$, $\mathrm{UO}_{2}\left(\mathrm{CO}_{3}\right)_{3}{ }^{-4}, \mathrm{CaUO}_{2}\left(\mathrm{CO}_{3}\right)_{3}{ }^{-2}$, and $\mathrm{Ca}_{2} \mathrm{UO}_{2}\left(\mathrm{CO}_{3}\right)_{3}{ }^{0}$ (Dong and Brooks 2006; Zachara et al. 2007b). These stable complexes cause high uranium solubility, and a stable uranium solution that may be transported for significant distances before recovery. A slightly alkaline carbonate solution that does not contain oxidants is selective to uranium without significantly increasing other metal solubilities or dissolving primary minerals. However, this solution also results in potentially low recoveries $(5 \%-87 \%$ of both adsorbed and mineral phases) because the $\mathrm{pH}$ is not low or high enough to dissolve some uraniumcontaining minerals (ORNL 1993). It is estimated that $60 \%$ to $80 \%$ of uranium can be recovered from a uranium deposit by the alkaline-carbonate ISR process (Taylor et al. 2004; Pelizza 2008). Mason et al. (1997) observed $75 \%-95 \%$ recovery when using carbonate solutions to remove uranium from contaminated soil, which they mentioned is approximately the amount of oxidized uranium in the soil. Mason et al. (1997) suggested that the carbonate removed both adsorbed and either uranium released from mineral structures or by diffusive mass transfer from dead-end pores; they further confirm that carbonate is specific to uranium without significant amounts of dissolved minerals or metals being released.

Phillips et al. (1995) combined bicarbonate extraction with microbially induced reductive precipitation for isolating concentrated uranium. Kulpa and Hughes (2001) reported up to $90 \%$ adsorbed phase extraction efficiency. Additionally, Zhou and Gu (2005) observed 82\% recovery, and showed that carbonate leaching mechanisms include the dissolution of U(VI) phosphate and other mineral phases, the oxidation-complexation of U(IV) under oxic conditions, and the desorption of U(VI) from organic matter at elevated $\mathrm{pH}$. Carbonate seems to be applicable for soil concentrations of uranium ranging from $<450$ to $>50 \mathrm{mg} / \mathrm{kg}$ (ORNL 1993). The uranium recoveries seem to be insensitive to $\mathrm{pH}$ from $8-10$ (Francis et al. 1993). Alkaline leaching is generally considered to have slower kinetics relative to acid leaching systems. Permanganate may be added to carbonate extractions to ensure complete uranium oxidation for carbonate complexation (ORNL 1993). However, manganese oxide formation may inhibit uranium transport and removal.

The carbonate extraction method assumes that additional carbonate in solution will alter the uranium speciation. The amount of uranium extracted generally increases with increasing carbonate concentration, whereas this effect may diminish above approximately $0.5 \mathrm{M}$ (Zhou and $\mathrm{Gu} 2005$ ). There may be competing processes impacting uranium mobility as coupled to the carbonate system. Certainly, the impact of additional carbonate in solution leads to the increase of uranium-carbonate aqueous complexes, which may lead to increases in uranium solubility or desorption. However, assuming calcium availability, increases in carbonate may supersaturate the solution with respect to carbonate minerals, which would lead to precipitation. The formation of carbonate minerals could actually increase the uranium retention through increases in adsorption sites and co-precipitation.

The average groundwater at the Hanford Site has approximately $2.6 * 10^{-5} \mathrm{~mol} / \mathrm{L} \mathrm{CO}_{3}^{-2}$, which is essentially at equilibrium with carbonate minerals. Thus, the injection of additional carbonate at the 
200 Area may not significantly decrease the desorption behavior of uranium. It may result in the precipitation of carbonate minerals, which can increase the retention of uranium as mentioned above. Additionally, carbonate would not likely dissolve primary minerals, which suggests that complete uranium extraction is unlikely and so is the mobilization of significant amounts of other potentially hazardous compounds into the leaching solution waste stream. However, injection of bicarbonate (or $\mathrm{CO}_{2}$ gas) would lead to $\mathrm{pH}$ reductions and acidic dissolution of minerals.

Citric Acid Solutions: Citrate forms mixed-metal complexes with several metals (Adin et al. 1970; Binder 1971; Markovits et al. 1972). Citrate is known to form strong complexes with uranium (Rajan and Martell 1965) and citrate also forms U-Fe-citrate complexes (Manzurola et al. 1989; Dodge and Francis 1997, 2003), which Kantar et al. (2005) suggest are quite stable and effective for removal of adsorbed uranium.

Citrate appears to be a good uranium extractant at low $\mathrm{pH}(<3)$ values because it dissolves carbonate minerals and oxide coatings on sediments, and decreases uranium adsorption. Kantar and Honeyman (2006) suggest that citric acid is highly effective in removing uranium, and the extraction efficiency increases with increasing citric acid concentration under slightly acidic to alkaline conditions. Citrate typically has high uranium extraction efficiency (95\%-60\% mineral and adsorbed phases), which does decrease with increasing $\mathrm{pH}$ and increases with increasing citrate concentration (ORNL 1993). Kantar and Honeyman (2006) reported recoveries of $97.5 \%$ of adsorbed uranium using $0.1 \mathrm{M}$ citrate, which is attributed to removal of adsorbed uranium and uranium bound within or passivated by Fe amorphous oxides coating mineral surfaces.

Citrate degrades over the long-term naturally, which decreases waste generation and environmental impact (Huang et al. 1998). Citrate may be obtained inexpensively as a waste product from various industries. It also allows for a buffered extraction system even after dissolution of carbonate minerals, which suggests consistent extraction and stable uranium-citrate transport for significant distances (compared to other acid extractions such as sulfuric) (ORNL 1993). Citrate does also complex iron and aluminum, which allows for increased uranium extraction with removal of oxide coatings on mineral surfaces. Complexation competition with significant amounts of other metals may possibly limit the uranium extraction in some situations. The stability of complexation suggests the potential for transport significant distances in the subsurface without maintaining reagent injection. As with carbonate, citrate would not likely dissolve primary minerals, which suggests that complete uranium extraction is unlikely and so is the mobilization of significant amounts of other potentially hazardous compounds into the leaching solution waste stream.

Sulfuric Acid Solutions: Sulfuric acid is an inexpensive (relative to nitric acid) strong acid that has been commonly used in solution mining (Bartlett 1998). Application of this acid allows for efficient uranium extraction $(>90 \%$ mineral and adsorbed phases) at low $\mathrm{pH}(<2)$ values (ORNL 1993) where uranium and other mineral solubilities are increased, and mineral dissolution-as well as desorptionremove uranium from all phases. The U(VI) also forms highly soluble complexes with sulfate.

Additional acid, relative to the amount required to mobilize uranium, would be required to maintain low $\mathrm{pH}$ and uranium solubility because the acid becomes neutralized through mineral dissolution. Thus, significant quantities of acid would be required to overcome the natural acid neutralization potential of the sediment and to maintain uranium extraction during transport and removal from the subsurface. In particular, the presence of significant amounts of calcite in the 200 Area sediments (Zachara et al. 2007b) 
would be expected to consume significant amounts of acid. Additionally, the low $\mathrm{pH}$ values achieved by sulfuric acid applications increase the solubilities of most minerals and metals, which would lead to a potentially hazardous leaching solution waste stream (Merritt 1971; Duff et al. 1998).

Acid ISR has been employed only at a few research and development sites in the United States, but has been used for uranium recovery at sites located in Eastern Europe and Asia, as well as the Beverley Mine site in Australia. Reported compositions of acid ISR lixiviants are summarized in Table 1.2.

Leaching was conducted at the Nine Mile Lake site using 3 to $5 \mathrm{~g} / \mathrm{L}$ sulfuric acid and $1 \mathrm{~g} / \mathrm{L}$ hydrogen peroxide. The test leaching was considered successful, although some gypsum precipitation was noted during testing (Mudd 2000a). A similar acid ISR test was carried out at the Reno Ranch site in Wyoming. During acid ISR testing at Reno Ranch, problems were also encountered that were partly attributed to gypsum precipitation (Mudd 2000a). The results of acid ISR testing at these sites indicate that gypsum precipitation and consequent loss of permeability can be a significant limitation.

The lixiviant composition reported in Table 1.2 for the Beverley Mine site was obtained from the Northern Field Leach Trial (Mudd 2000a). Lixiviant at the Beverley Mine site includes sulfuric acid and hydrogen peroxide (Jeuken et al. 2008). Limited data are available for the Bulgarian sites described by Mudd (2000b), although the acid leaching solution application generally progressed from a few months of acid levels up to $10 \mathrm{~g} / \mathrm{L}$, followed by more than 2 years of acid levels from 4 to $6 \mathrm{~g} / \mathrm{L}$ and a final closeout period with acid levels at 0.5 to $1 \mathrm{~g} / \mathrm{L}$. The total leaching period at these sites was between 3 to 5 years and uranium recovery was approximately $60 \%$ to $80 \%$ (Mudd 2008b).

Acid in situ leaching at the Stráz Pod Ralskem site in the Czech Republic was complicated by slow uranium dissolution rates, which necessitated the use of a number of chemicals in the leaching solution, including sulfuric acid, ammonia, nitric acid and hydrofluoric acid (Mudd 2000b). Use of these compounds in the leaching fluid accounts for the high ammonium, fluoride, and nitrate concentrations in the lixiviant (Table 1.2).

Trial leaching at the site in Yining, China, was carried out for 92 days using sulfuric acid and hydrogen peroxide (Mudd 2008b). Sulfuric acid concentrations in the injectate were initially $20 \mathrm{~g} / \mathrm{L}$, were gradually increased to $80 \mathrm{~g} / \mathrm{L}$, and were later reduced to 4 to $6 \mathrm{~g} / \mathrm{L}$. Hydrogen peroxide concentrations up to $0.55 \mathrm{~g} / \mathrm{L}$ were used at the site in Yining, China.

Facilitated Transport: Facilitated transport is the application of an agent that forms a complex with uranium, thereby facilitating and enhancing the transport of uranium through the subsurface for increased extraction efficiency. Essentially, the fraction of uranium that is complexed is above and beyond the normal uranium solubility, which suggests that complexation enhances the uranium solubility and the removal efficiency. As mentioned above, the stability of complexation suggests the potential for transport of significant distances in the subsurface without maintaining reagent injection.

There are several organic and inorganic chelating agents that have been used to extract uranium (Langmuir 1978; Waite et al. 1994; Brendler et al. 1995; Pabalan and Turne 1997; Pabalan et al. 1998; Yousfi et al. 1999; Fjeld et al. 2000; Wade et al. 2000; Winde 2002; Gupta and Singh 2005). Citrate is a popular example for uranium. Other examples include organic chelating agents and surfactants (Armiran and Wilde 1992; Gadelle et al. 2001). Siderophores (such as tiron, acetyl hydroxamic acid, and catechol) 
Table 1.2. Lixiviant concentrations reported for acid ISR operations

\begin{tabular}{|c|c|c|c|c|c|}
\hline Constituent & $\begin{array}{l}\text { Nine Mile Lake, } \\
\text { Wyoming }^{(a)}\end{array}$ & Beverley, Australia $^{(a)}$ & $\begin{array}{c}\text { Bulgaria (Summary of } \\
13 \text { Sites })^{(b)}\end{array}$ & $\begin{array}{l}\text { Stráz Pod Ralskem, } \\
\text { Czech Republic }^{(b)}\end{array}$ & Yining, China $^{(b)}$ \\
\hline Calcium & 260 & 600 & $140-600$ & $200-300$ & 17 \\
\hline Magnesium & NR & 337 & $140-330$ & $20-30$ & 140 \\
\hline Sodium & NR & 1,430 & $30-900$ & $10-15$ & 172 \\
\hline Potassium & NR & 59 & $30-200$ & $40-70$ & 28 \\
\hline Chloride & NR & 2,000 & NR & NR & 762 \\
\hline Fluoride & NR & 7.33 & NR & $100-300$ & 5.2 \\
\hline Nitrate & NR & NR & NR & $200-1,400$ & NR \\
\hline Phosphate & NR & NR & NR & $153-460$ & 22 \\
\hline Sulfide & NR & NR & NR & NR & 2.7 \\
\hline Sulfate & $\leq 8,000$ & 4,840 & $10,000-12,000$ & $33,000-80,000$ & 22,800 \\
\hline pH (standard units) & $1.5-2.0$ & 1.97 & $1.4-2.0$ & 0.5 & 1.26 \\
\hline Total dissolved solids & NR & 11,700 & $15,000-20,000$ & $50,000-100,000$ & NR \\
\hline Aluminum & NR & 91 & $310-840$ & $4,000-6,000$ & 323 \\
\hline Ammonium & NR & NR & NR & $1,000-2,000$ & NR \\
\hline Antimony & NR & NR & NR & NR & 0.4 \\
\hline Arsenic & NR & NR & NR & NR & 0.1 \\
\hline Barium & NR & 0.039 & NR & NR & NR \\
\hline Boron & NR & 1.1 & NR & NR & NR \\
\hline Cadmium & NR & 0.116 & NR & NR & 0.4 \\
\hline Chromium & NR & 0.58 & NR & $5-15$ & 0.74 \\
\hline Cobalt & NR & 20 & NR & NR & NR \\
\hline Copper & NR & 0.20 & NR & NR & 0.5 \\
\hline
\end{tabular}


Table 1.2. (contd)

\begin{tabular}{|c|c|c|c|c|c|}
\hline Constituent & $\begin{array}{l}\text { Nine Mile Lake, } \\
\text { Wyoming }^{(a)}\end{array}$ & Beverley, Australia ${ }^{(a)}$ & $\begin{array}{c}\text { Bulgaria (Summary of } \\
13 \text { Sites })^{(b)}\end{array}$ & $\begin{array}{l}\text { Stráz Pod Ralskem, } \\
\text { Czech Republic }^{\left({ }^{b}\right)}\end{array}$ & Yining, China ${ }^{(b)}$ \\
\hline Iron & $\leq 200$ & 105 & $700-2,200$ & $500-1,500$ & 817 \\
\hline Lead & NR & 0.79 & NR & NR & 0.67 \\
\hline Molybdenum & NR & NR & NR & NR & 2.4 \\
\hline Nickel & NR & 8.33 & NR & $20-30$ & 1.3 \\
\hline Scandium & NR & NR & NR & NR & 1.86 \\
\hline Selenium & NR & 0.410 & NR & NR & 0.001 \\
\hline Silica & NR & 283 & $133-221$ & $100-200$ & NR \\
\hline Thorium-230 (pCi/L) & $49,000 \pm 3,200$ & NR & NR & NR & NR \\
\hline Uranium & $80-150$ & 162 & $5-30$ & $1-500$ & 75 \\
\hline
\end{tabular}


are low molecular weight extracellular chelators produced by microbes, and these chelators tend to have high binding constants for metal cations (ORNL 1993). Tiron and catechol siderophores form stable negatively charged complexes and increase solubility and mobility of uranium. Surfactants are generally long-chained organic compounds that are amphiphilic, which indicates that they contain both hydrophobic and hydrophilic functional groups. Some surfactants tend to form complexes with ionic species and the hydrophilic functional groups.

One advantage of these agents is the potential for near-neutral $\mathrm{pH}$ applications, which minimizes primary mineral dissolution and the associated potentially hazardous leaching solution waste stream processing issues. However, likely due to uranium solubility limits within this $\mathrm{pH}$ range (ORNL 1993), the surfactants and chelating agents have low uranium extraction efficiency $(2 \%-8 \%$ adsorbed and mineral phases), because they cannot access uranium trapped as a co-precipitate in carbonate and silicate mineral phases. Gadelle et al. (2001) reported uranium removal through desorption using surfactants. Gadelle et al. (2001) also report the surfactants used were very efficient for uranium removal at low uranium concentrations, and at higher concentrations 75\%-80\% adsorbed phase removal was achieved. However, adsorption of surfactants themselves, which can be significant for some sites or conditions, may limit extraction and recovery efficiency.

Bisequential Citric Acid/Carbonate Leaching: Researchers have also examined the combination of soil flushing lixiviants for uranium, which may be useful for targeting uranium located and retained within both adsorbed and mineral phases. One promising method was developed as a combination of multiple extraction methods, which may be required for extraction of uranium when it is distributed within multiple phases and mineral structures.

The bisequential extraction procedure first uses the citrate-bicarbonate-dithionite (CBD) method that uses citric acid in combination with dithionite followed by ammonium-carbonate extraction with potassium permanganate (Jackson et al. 1986). This method has been reported as highly effective for extraction ( $>90 \%-60 \%$ adsorbed and mineral phases) of both U(IV) and U(VI) even when it is entrapped within mineral structures (ORNL 1993). CBD uses reductive dissolution of iron, which weakens mineral structures, citrate complexes the iron, and bicarbonate buffers the $\mathrm{pH}$ to dissolve sesquioxides. The second extraction oxidizes the uranium to form a stable carbonate complex for transport and extraction from the subsurface. This CBD reductive-dissolution process of iron oxide dissolution appears to significantly increase the efficiency of uranium extraction, although manganese oxide formation resulting from the permanganate treatment may inhibit uranium transport and removal. In addition, CBD does dissolve some calcite; however, at the reaction $\mathrm{pH}$ of 7.3 the amount of waste production and potential for hazardous compound mobilization will likely be minimal (ORNL 1993).

This method involves multiple injection solutions at two separate injection times, and it uses both acid-base and oxidation-reduction reactions. The comprehensive nature of this extraction is evident in its extraction efficiency, whereas this method is rather complex for field-scale applications. Effectively conducting sequential extractions in the field over a significant volume of the subsurface may be limited by unsaturated pore water velocities as well as hydraulic conductivity heterogeneity. In addition, the need to consider both U(IV) and U(VI) within a soil flushing design at the 200 Areas may be questionable as the uranium is mainly in the oxidized state.

Summary of Leaching Solutions: Several types of leaching solutions have been used to extract uranium from sediments. Table 1.3 summarizes the main extraction processes. Although these various 
treatment applications can be classified in terms of the extraction mechanisms and potential limitations, the uranium removal efficiency depends on the geochemistry of the sediment and the uranium phase distribution.

Table 1.3. Summary of extraction processes and potential for field application at the Hanford Central Plateau

\begin{tabular}{|c|c|c|c|c|}
\hline $\begin{array}{l}\text { Extraction } \\
\text { Method }\end{array}$ & $\begin{array}{c}\text { Process } \\
\text { Description }\end{array}$ & $\begin{array}{c}\text { Main } \\
\text { Advantage }\end{array}$ & $\begin{array}{l}\text { Main Uncertainty or } \\
\text { Disadvantage }\end{array}$ & $\begin{array}{c}\text { Field } \\
\text { Consideration }\end{array}$ \\
\hline Carbonate solutions & $\begin{array}{c}\text { Alkaline } \\
\text { complexation }\end{array}$ & $\begin{array}{l}\text { Experience at } \\
\text { field scale }\end{array}$ & $\begin{array}{l}\text { Mild extraction, may } \\
\text { not meet uranium } \\
\text { removal goal }\end{array}$ & $\begin{array}{l}\text { Potential mineral } \\
\text { formation }\end{array}$ \\
\hline Citric acid solutions & Complexation & $\begin{array}{l}\text { Experience at } \\
\text { field scale }\end{array}$ & $\begin{array}{l}\text { Mild extraction, may } \\
\text { not meet uranium } \\
\text { removal goal }\end{array}$ & $\begin{array}{l}\text { Feasible for field } \\
\text { application }\end{array}$ \\
\hline Sulfuric acid solutions & Acid dissolution & Harsh extraction & $\begin{array}{l}\text { Acid consumption } \\
\text { and waste processing }\end{array}$ & $\begin{array}{l}\text { Acid amount } \\
\text { prohibitive and } \\
\text { potential leaching } \\
\text { risks }\end{array}$ \\
\hline Facilitated transport & Complexation & $\begin{array}{l}\text { Experience at } \\
\text { field scale }\end{array}$ & $\begin{array}{l}\text { Mild extraction, may } \\
\text { not meet uranium } \\
\text { removal goal }\end{array}$ & $\begin{array}{l}\text { Field feasible with } \\
\text { limited extraction } \\
\text { efficiency }\end{array}$ \\
\hline $\begin{array}{l}\text { Bisequential citric } \\
\text { acid/carbonate } \\
\text { leaching }\end{array}$ & Combination $^{\text {(a) }}$ & Harsh extraction & $\begin{array}{l}\text { Sequential operation, } \\
\text { no field experience }\end{array}$ & $\begin{array}{l}\text { Field application too } \\
\text { complex and no need } \\
\text { for U oxidation }\end{array}$ \\
\hline
\end{tabular}

(a) Combination sequential extraction including acid with reductive dissolution before oxidation and alkaline extraction.

Table 1.3 illustrates that, in general, the harsh soil flushing solutions that would extract a significant amount of the uranium are problematic because they react with co-contaminants and soil minerals or are not appropriate for field application. The mild extraction solutions are typically applied along with oxidation of reduced-phase uranium for mining purposes. For Hanford where the uranium is not in a reduced condition, the mild extraction solutions may not be harsh enough for complete extraction, and the feasibility of their application for remediation would require an assessment of whether incomplete extraction of uranium is sufficient to meet remediation goals. However, based on the review of prior investigations, carbonate and citric acid flushing solutions may be suitable for extracting the currently mobile fractions of the uranium (i.e., adsorbed and dissolved uranium in the pore water). Removal of the mobile fraction of uranium may be a sufficient to meet remediation goals. The most mobile fraction poses the highest risk to groundwater, and there is a possibility that the rate of release for the more refractory phases may be slow enough to be protective of the groundwater system.

Potential limitations for ISR of uranium may also represent issues impacting the feasibility of soil flushing for 200 Area sediments. Stewart (2002) examined post-ISR mineralogical samples and other data from well fields in Wyoming and Nebraska to identify factors that may limit uranium recovery. Factors limiting the recovery of uranium at these sites included precipitation of oxidized uranium solid phases, such as carnotite $\left[\mathrm{K}_{2}\left(\mathrm{UO}_{2}\right)_{2}\left(\mathrm{VO}_{4}\right)_{2} \cdot 3 \mathrm{H}_{2} \mathrm{O}\right]$, channeling of lixiviant within the formation that 
minimized contact between uranium-bearing minerals and the solution phase, and the presence of organic material and pyrite $\left[\mathrm{FeS}_{2}\right]$ in the solid phases that consumed oxidant. Channeling of lixiviant within the formation is known as preferential flow, which can be significant in heterogeneous and variably saturated subsurface systems. Preferential flow may limit the solution/mineral contact and sweeping efficiency during soil flushing application. 


\subsection{Framework of Evaluation}

The evaluation of soil flushing for the Hanford Central Plateau included three primary elements. First, a review of literature was conducted to evaluate fluid extraction processes used elsewhere and how those processes relate to potential application at the Hanford Site. This information is provided in Section 1.0. Next, the impact of the subsurface properties in the Hanford Central Plateau on water infiltration and contaminant flushing was investigated through numerical modeling (Section 3.0). In these studies, contaminant transport was simulated for solutes that were assigned a range of soil partitioning coefficients. In this way, the results can be interpreted for nonsorbing contaminants such as technetium and for sorbing contaminants such as uranium. The soil partitioning coefficient would be a function of the contaminant properties and the impact of the leaching solution properties. Laboratory flow-cell experiments were also conducted to demonstrate water infiltration and contaminant flushing as a function of subsurface properties and to provide data for comparison to the numerical simulations (Section 4.0). 


\subsection{Modeling Study of Water Infiltration and Contaminant Flushing}

Simulations were conducted to evaluate water infiltration and contaminant flushing as a function of subsurface properties for the Hanford Central Plateau. Recently published reports were used to configure a model of the subsurface for a nominal 200 West Area site and a nominal 200 East Area site. Variations in subsurface properties and flushing parameters were used to evaluate factors influencing the effectiveness of contaminant flushing.

\subsection{Geology and Hydraulic Properties}

The general stratigraphy of lithologic units beneath the 200 West Area (Figure 3.1) was based on that described by Last et al. (2009a) and Last et al. (2009b) and use the layer identification nomenclature from these reports. The mean thicknesses of layers provided in these reports were used in the simulation. Using Hanford Site data and a similar approach to that described by Last et al. (2009a), the general stratigraphy of lithologic units beneath 200 East Area (Figure 3.1) were assigned. In this effort, the mean layer thicknesses for the southern half of the 200 East Area were identified. Additionally, an H2 Lens was imposed as a hypothetical layer representing a potential high-silt zone in the $\mathrm{H} 2$ layer.

Representative hydraulic properties from sediment classes in Last et al. (2009b) were assigned to each hydrostratigraphic unit. Hydrologic parameter values for each of these sediment classes were derived from Last et al. (2006) and Last et al. (2009b). Last et al. (2006) provided statistical distributions of van Genuchten model (van Genuchten 1980) parameters ( $\alpha, \mathrm{n}, \theta \mathrm{r}, \theta \mathrm{s}$ ) and saturated hydraulic conductivity $(\mathrm{Ks})$. Bulk density data were derived from laboratory data contained in a prototype hydraulic properties database (Last et al. 2009b). When a geological unit contained more than one sediment class, only one of the sediment classes was selected in the simulations. The representative hydraulic properties of the geological units and selected sediment classes are summarized in Table 3.1 for the 200 West Area and in Table 3.2 for the 200 East Area. Generally, for both areas the top-most and the bottom-most layers have relatively larger saturated hydraulic conductivity values than those in between.

The CCU in the 200 West Area, and potentially high-silt zones within the 200 East Area, are expected to have significant impacts on contaminant transport due to a relatively low hydraulic conductivity compared to surrounding materials. The typical saturated hydraulic conductivity values for these layers listed in Tables 3.1 and 3.2 reflect the averaging scheme used by Last et al. (2009a, 2009b) and may not reflect the values beneath a specific waste site. For example, a thin caliche layer, which has very low hydraulic conductivity, is often present in the 200 West Area. Additionally, the silt content of the CCU varies across the Hanford Site. Thus, during the simulations, the saturated hydraulic conductivity and the thickness of the CCU layer in the 200 West Area and imposed high-silt zones within the 200 East Area were varied. Details about the variations are provided in the next section. 
(a)

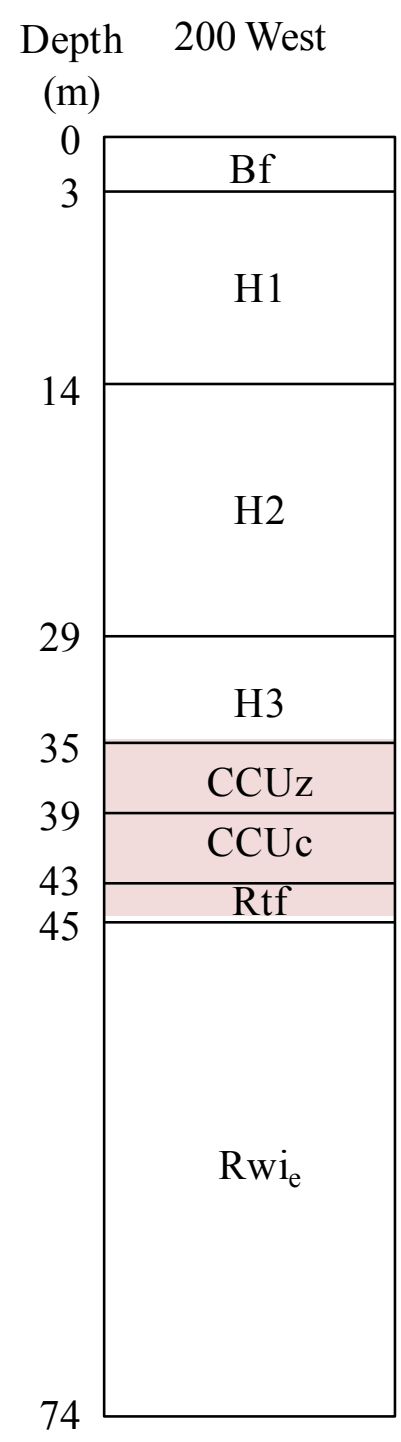

(b)

Depth 200 East

(m)

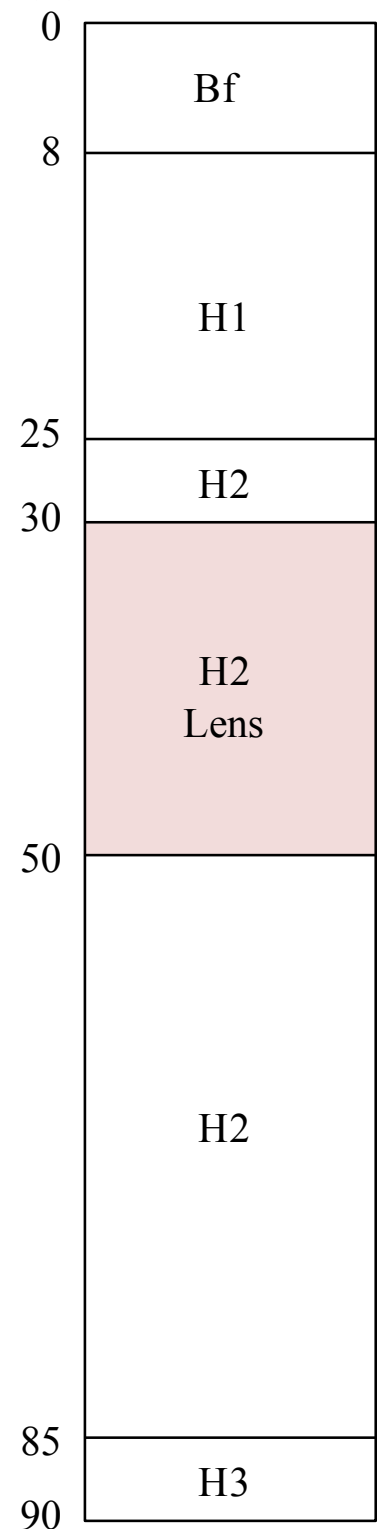

Figure 3.1. Generalized lithostratigraphy illustrating the mean thicknesses for the $200 \mathrm{West}$ Area and the southern half of the 200 East Area. The H2 Lens is a hypothetical layer representing a potential high-silt zone in the $\mathrm{H} 2$ layer. The highlighted regions show the assumed location of initial contaminant plumes. 
Table 3.1. Representative hydraulic properties of the 200 West Area

\begin{tabular}{lcccccccc}
\hline $\begin{array}{c}\text { Geo Unit } \\
\begin{array}{c}\text { Sediment } \\
\text { Class) }\end{array}\end{array}$ & $\begin{array}{c}\rho_{\mathrm{p}} \\
\left(\mathrm{g} / \mathrm{cm}^{3}\right)\end{array}$ & $\theta_{\mathrm{s}}$ & $\theta_{\mathrm{r}}$ & $\mathrm{S}_{\mathrm{r}}$ & $\begin{array}{c}\alpha \\
(1 / \mathrm{cm})\end{array}$ & $\mathrm{n}$ & $\mathrm{K}_{\mathrm{s}}(\mathrm{cm} / \mathrm{s})$ & $\alpha_{\mathrm{L}}(\mathrm{m})$ \\
\hline $\mathrm{Bf}(\mathrm{Bf})$ & 2.456 & 0.262 & 0.030 & 0.103 & 0.019 & 1.400 & $5.98 \mathrm{E}-04$ & 0.090 \\
$\mathrm{H} 1$ (Hcs) & 2.679 & 0.317 & 0.035 & 0.099 & 0.038 & 1.945 & $1.09 \mathrm{E}-03$ & 0.203 \\
$\mathrm{H} 2$ (Hfs) & 2.517 & 0.356 & 0.042 & 0.118 & 0.010 & 2.177 & $3.67 \mathrm{E}-05$ & 0.203 \\
$\mathrm{H} 3$ (Hss) & 2.582 & 0.398 & 0.057 & 0.141 & 0.005 & 2.116 & $1.91 \mathrm{E}-05$ & 0.031 \\
$\mathrm{CCUz}$ & 2.785 & 0.419 & 0.040 & 0.097 & 0.005 & 2.249 & $5.57 \mathrm{E}-05$ & 0.031 \\
$\mathrm{CCUc}$ & 2.607 & 0.281 & 0.054 & 0.185 & 0.011 & 1.740 & $8.45 \mathrm{E}-04$ & 0.031 \\
Rtf $(\mathrm{CCUz})$ & 2.785 & 0.419 & 0.040 & 0.097 & 0.005 & 2.249 & $5.57 \mathrm{E}-05$ & 0.031 \\
Rwi (Rg) & 2.622 & 0.294 & 0.041 & 0.120 & 0.014 & 1.671 & $1.06 \mathrm{E}-04$ & 0.090 \\
\hline
\end{tabular}

Table 3.2. Representative hydraulic properties of the 200 East Area

\begin{tabular}{ccccccccc}
\hline $\begin{array}{c}\text { Geo Unit } \\
\text { (Sediment } \\
\text { Class) }\end{array}$ & $\begin{array}{c}\rho_{\mathrm{p}} \\
(\mathrm{g} / \mathrm{cm} 3)\end{array}$ & $\theta_{\mathrm{s}}$ & $\theta_{\mathrm{r}}$ & $\mathrm{S}_{\mathrm{r}}$ & $\begin{array}{c}\alpha \\
(1 / \mathrm{cm})\end{array}$ & $\mathrm{n}$ & $\mathrm{K}_{\mathrm{s}}(\mathrm{cm} / \mathrm{s})$ & $\alpha_{\mathrm{L}}(\mathrm{m})$ \\
\hline Bf (Bf_SW) & 2.456 & 0.262 & 0.030 & 0.103 & 0.019 & 1.400 & $5.98 \mathrm{E}-04$ & 0.090 \\
H1 (Hcs_BC) & 2.738 & 0.357 & 0.026 & 0.074 & 0.072 & 2.047 & $5.32 \mathrm{E}-03$ & 0.203 \\
H2 (Hfs_BC) & 2.860 & 0.380 & 0.033 & 0.089 & 0.021 & 2.507 & $2.25 \mathrm{E}-03$ & 0.203 \\
H3 (Hg_SW) & 2.601 & 0.167 & 0.022 & 0.134 & 0.017 & 1.725 & $3.30 \mathrm{E}-04$ & 0.090 \\
\hline
\end{tabular}

\subsection{Model Configuration}

Three sets of simulations were conducted to investigate the effect of the following factors on contaminant flushing to the groundwater:

I. Impacts of infiltration rate. In addition to the base infiltration rate of $52 \mathrm{~cm} / \mathrm{d}$ (30 gpm over an area of $314 \mathrm{~m}^{2}$ ), infiltration rates were varied by factors of $0.5,0.1$, and 0.01 from the base case configuration.

II. Impacts of the conductivity and thickness of the CCU (200 West Area) or imposed silt lens (200 East Area). Both the thickness and hydraulic conductivity of the CCU (200 West Area) or the imposed silt lens (200 East Area) were varied by factors of 0.5, 0.1, and 0.01 from the base case configuration (values in Figure 3.1 and Tables 3.1 and 3.2). Note that the geological units $\mathrm{CCUz}, \mathrm{CCUc}$, and Rtf were combined into one $\mathrm{CCU}$ zone, which took the hydraulic parameters of CCUz.

III. Impacts of the properties of flushing fluid. The fluid densities of 1 and $1.05 \mathrm{~g} \mathrm{~cm}^{-3}$ and viscosities of 1 and $0.8 \mathrm{cP}$ were considered in the simulations. These simulations were carried out only for the 200 West Area model. 
Base Cases. A base case simulation was conducted for each set of simulations (i.e., base case I, II, and III) using the base parameter values for each area in Figure 3.1, and Tables 3.1 and 3.2, and with a fluid density of $1 \mathrm{~g} \mathrm{~cm}^{-3}$ and viscosity of $1 \mathrm{cP}$.

Contaminant Zone. It was assumed that the contaminated zone had a cylindrical shape with a $10-\mathrm{m}$ radius. This assumption allowed simulations to be conducted in radial coordinates. The plume in the 200 West Area had a 10-m vertical thickness from 35 to $45 \mathrm{~m}$ bgs (Figure 3.1a). The plume in the 200 East Area had a 20-m vertical thickness from 30 to $50 \mathrm{~m}$ bgs (Figure 3.1b). Thus, the bulk volume of the contaminant zone was $3140 \mathrm{~m}^{3}$ in the $200 \mathrm{West}$ Area and $6280 \mathrm{~m}^{3}$ in the 200 East Area. Contaminants with different sorption properties were denoted by $\mathrm{S}_{-} \mathrm{xx}$, where " $\mathrm{xx}$ " is the sorption coefficient. Contaminants with six different sorption coefficients, $\mathrm{k}_{\mathrm{d}}$, of $0,0.1,0.3,1,3$, and $10 \mathrm{~cm} \mathrm{~g}^{-1}$ were considered.

Infiltration Area. It was assumed that the infiltration area at ground surface was a circle with a $10-\mathrm{m}$ radius $\left(314 \mathrm{~m}^{2}\right)$ and was aligned with the contaminant plume vertically. During flushing, the infiltration area was kept saturated but with a zero ponding depth for simulation set II. Constant infiltration rates were enforced for simulation sets I and III.

Simulation Domain. Because of the horizontally layered structure, the flow from the infiltration area and contaminant transport due to the flow were expected to be axisymmetrical over the vertical line through the centers of the infiltration area and the contaminant zone. Hence, the simulations were carried out using a two-dimensional vertical slice in a cylindrical system. To minimize the impact of the side boundary, the radius of the two-dimensional slice was set to be 10 times the radius of the infiltration area/contaminant zone. The two-dimensional slice extended vertically from ground surface to the water table.

Domain Discretization. To determine the appropriate grid spacing, preliminary simulations were conducted using constant grid spacing that varied from $0.1 \mathrm{~m}$ to $2.0 \mathrm{~m}$. Results show that, for the problem investigated, a grid spacing no more than $1 \mathrm{~m}$ produced similar contaminant breakthrough curve (Figure 3.2). The transport distance in the radial direction was very limited and thus the grid spacing was larger than $1 \mathrm{~m}$ in the region without contaminants. For simulation set I, a constant spacing of $0.5 \mathrm{~m}$ was used in both the radial and vertical directions. For simulation sets II and III, the two-dimensional slices were discretized with variable radial and vertical spacing. The radial spacing varied between 0.5 and $2.5 \mathrm{~m}$, with the smallest spacing near the infiltration area and largest spacing away from the infiltration area; the vertical spacing varied between 0.025 and $0.5 \mathrm{~m}$, with the smallest spacing near the center of the contaminant plume and largest spacing away from the plume.

Initial Conditions. The initial conditions for the 200 West Area and 200 East Area simulations are shown in Figures 3.3 and 3.4, respectively. These conditions correspond to a steady-state flow condition with a constant meteoric recharge of $63 \mathrm{~mm} / \mathrm{yr}$, a recharge estimate for disturbed, nonvegetated Hanford Site sand (Table 4.19 of Last et al. 2006). The initial contaminant concentration was set to $1 \mathrm{unit}^{-3}$ bulk soil. Thus, the initial total mass of each contaminant in the domain is 3140 units in the 200 West Area and 6280 units in the 200 East Area. Because of sorption by soil particles, the initial aqueous concentration was different for contaminants with different sorption coefficients. 


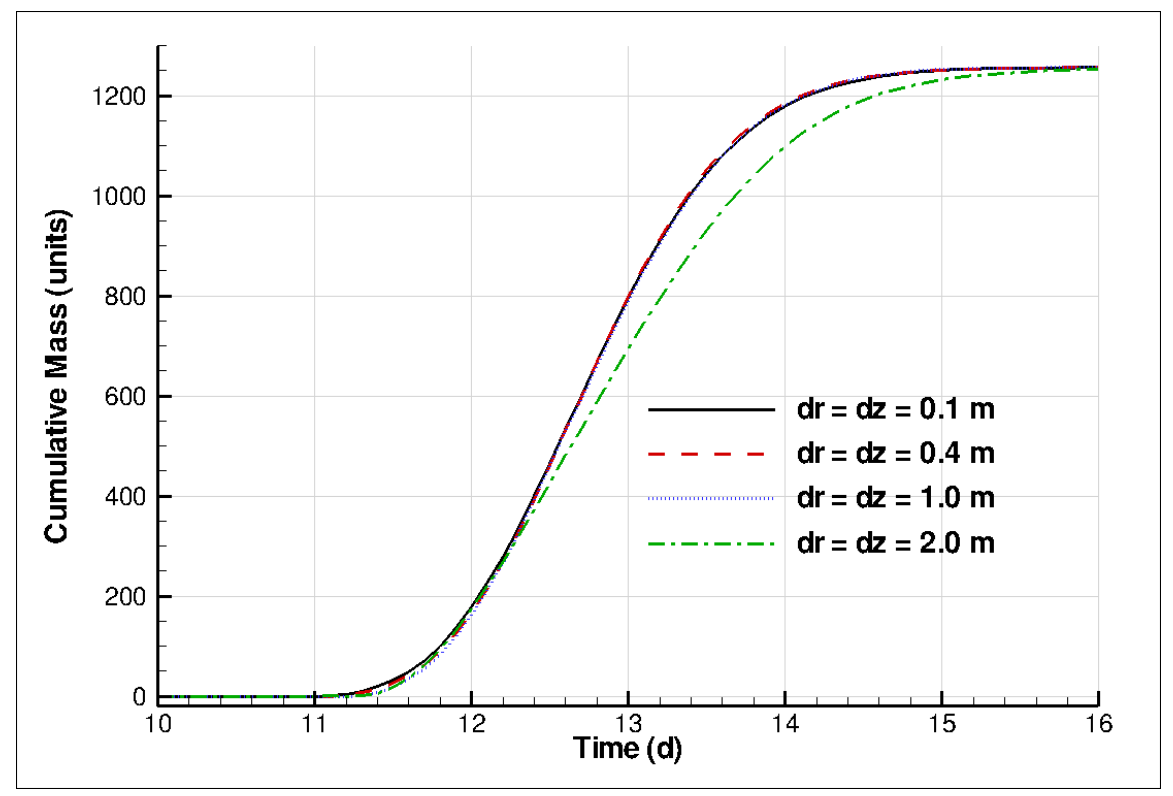

Figure 3.2. Impacts of grid spacing on the cumulative mass of a conservative (non-sorbing) contaminant entering into the groundwater. The total solute mass was 1256.6 units. $\mathrm{dr}=$ radial spacing; $\mathrm{dz}=$ vertical spacing.

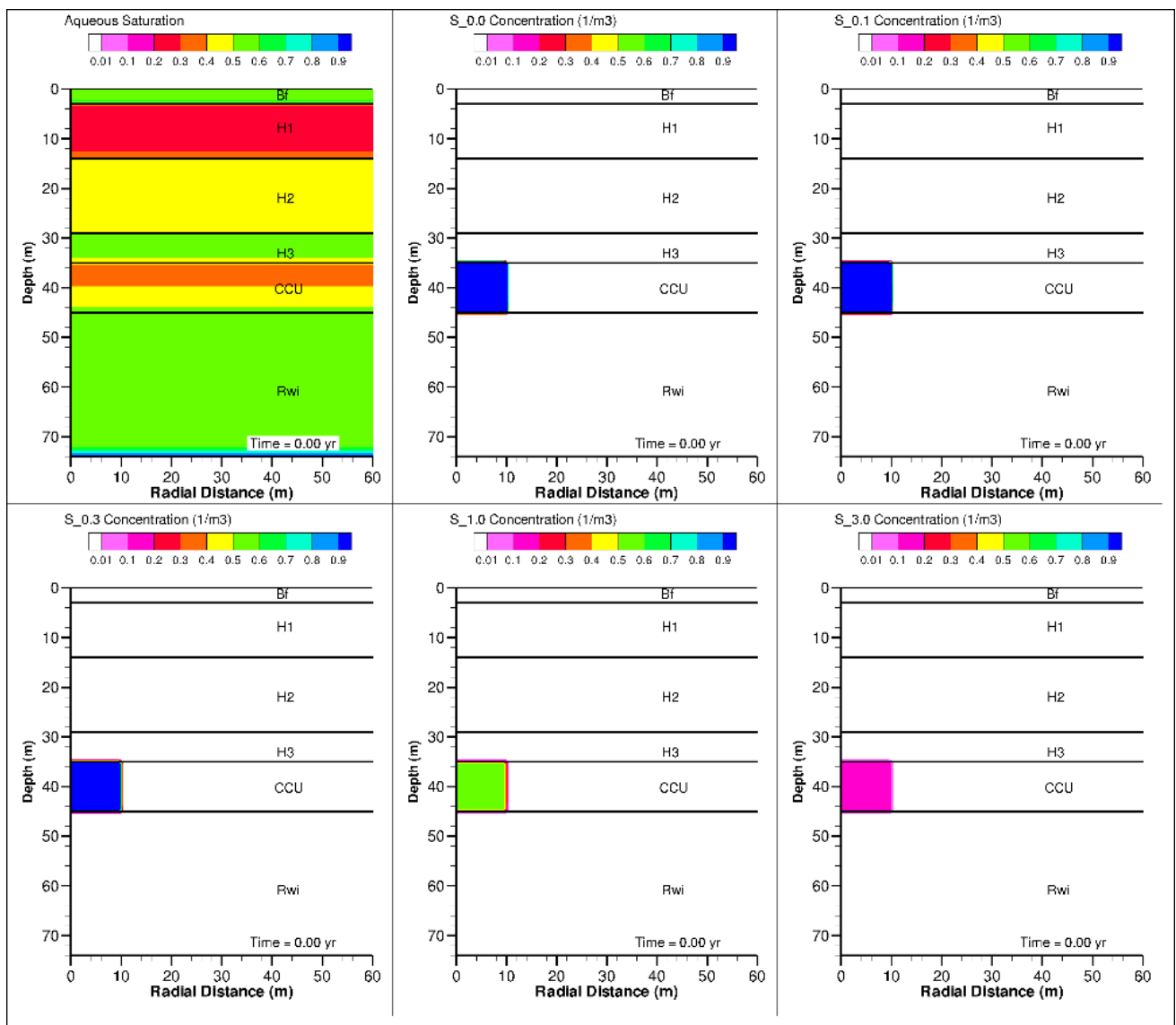

Figure 3.3. Initial distribution of saturation and aqueous contaminant concentrations for the 200 West Area 


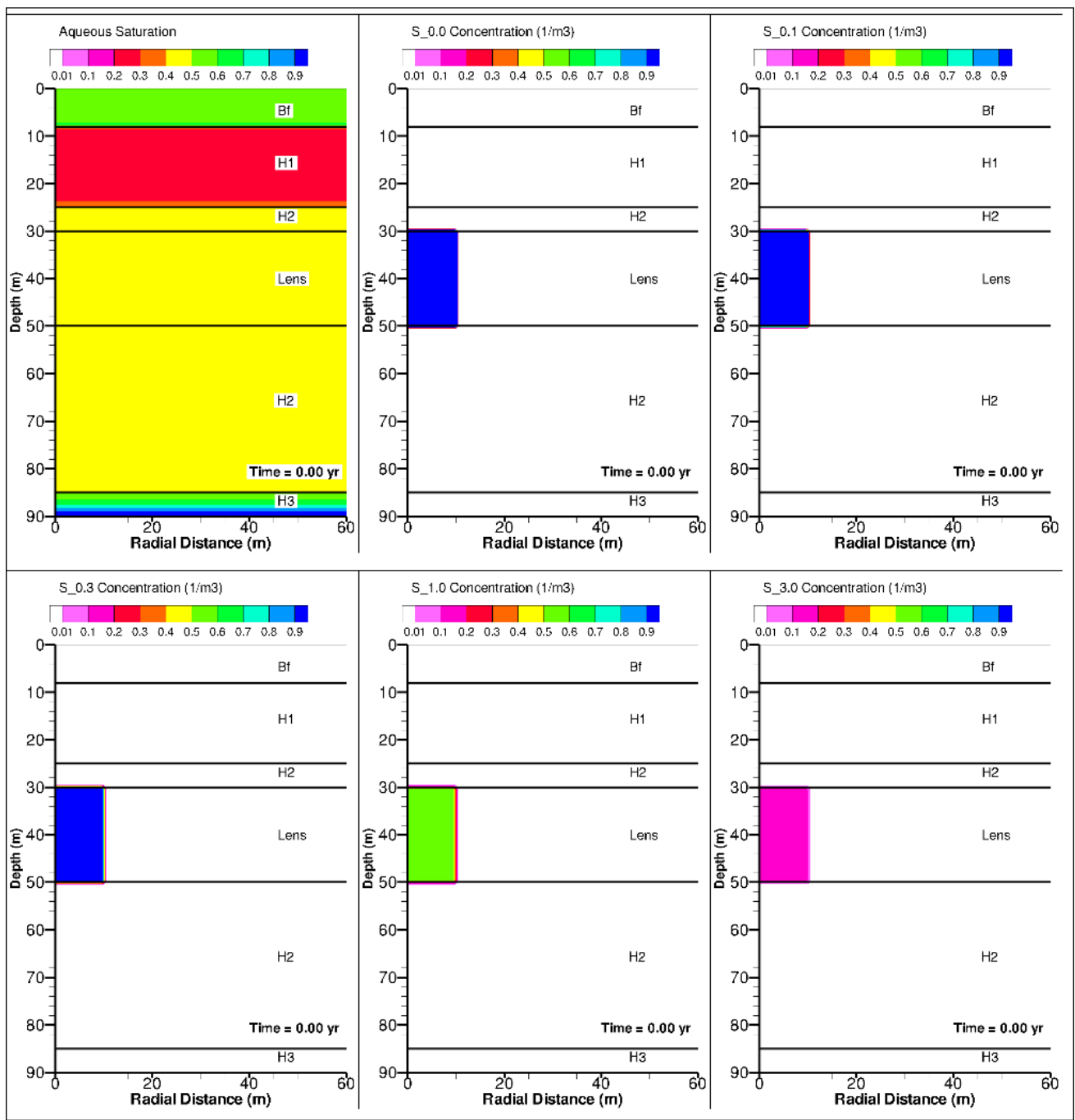

Figure 3.4. Initial distribution of saturation and aqueous contaminant concentrations for the 200 East Area

Boundary Conditions. The bottom of the domain was set as a groundwater boundary for flow and an outflow condition for transport. Outflow was applied to the side boundary for both flow and transport. The top boundary was different for each set of simulations. For simulation set I, a specified infiltration rate was applied with a base value equal to the saturated hydraulic conductivity of the top layer $(52 \mathrm{~cm} / \mathrm{d}$, which is equivalent to $30 \mathrm{gpm}$ over an area of $314 \mathrm{~m}^{2}$ ) and then variations by factors of $0.5,0.1$, and 0.01 . The infiltration rate for simulation set II was approximately $52 \mathrm{~cm} / \mathrm{d}$ for all cases and was applied as a constant-zero height ponding condition. The infiltration rate for simulation set III was $52 \mathrm{~cm} / \mathrm{d}$ for all cases. A constant flux of $63 \mathrm{~mm} \mathrm{yr}^{-1}$ was applied at the top boundary outside the infiltration area.

Numerical Simulator. The water mode of STOMP (Subsurface Transport Over Multiple Phases) (STOMP-W) with the Total Variation Diminishing (TVD) transport scheme, was used to simulate flow and contaminant transport. After preliminary simulations that examined the impacts of the maximum time step and the Courant number on transport, the maximum time step was limited to 0.1 days and the maximum Courant number was limited to 0.1 . The simulation time was 2 years. 


\subsection{Results}

This section summarizes the numerical simulation results.

\subsubsection{Base Case}

The results from the three base cases were functionally the same. Thus, only the results from base case II are presented.

Figure 3.5 shows the saturation distribution for the 200 West Area at selected times. Because the H1 unit is coarser than the overlying Bf layer, the flushing water flow was dominantly vertical within $\mathrm{H} 1$ but had significant lateral movement in the layers below; i.e., the $\mathrm{H} 2, \mathrm{H} 3, \mathrm{CCU}$, and Rwi units. Although the pond radius was $10 \mathrm{~m}$, the maximum radius of the 0.9 saturation zone was about $45 \mathrm{~m}$ in the $\mathrm{H} 3 \mathrm{unit}$.

Figure 3.6 shows the distribution of the aqueous concentration of the conservative contaminant for the 200 West Area at selected times. The contaminant did not move until the flushing water reached the plume at about 0.3 year. The plume then moved dominantly downwardly with the flushing water. The contaminant near the right edge of the plume moved at a slightly slower rate. There was very limited (about $0.2 \mathrm{~m}$ ) radial transport because flow direction was predominantly downward through the contaminated zone and the lateral dispersivity is assumed to be only $1 / 10$ of the longitudinal dispersivity.

Figure 3.7 shows the saturation distribution for the 200 East Area at selected times. The flow pattern was similar to that of the $200 \mathrm{West}$ Area. The maximum radius of the 0.9 saturation zone was about $40 \mathrm{~m}$ in the $\mathrm{H} 2$ unit. Figure 3.8 shows the distribution of the aqueous concentration of the conservative contaminant for the 200 East Area at selected times. The transport process was similar to that in the 200 West Area.
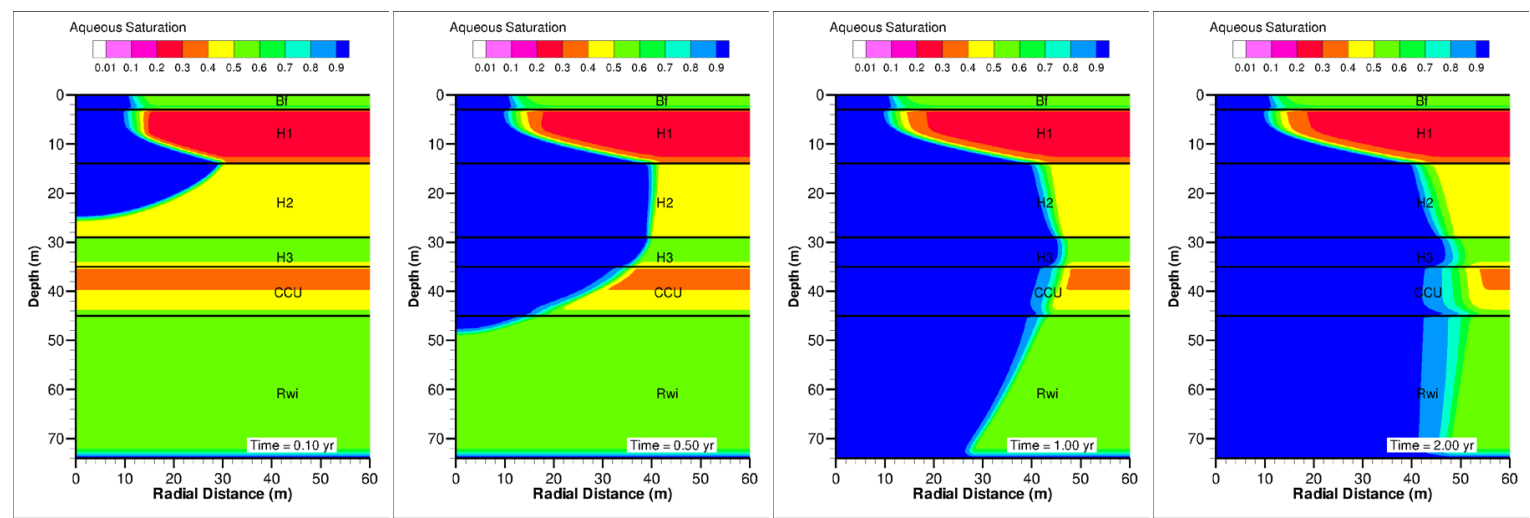

Figure 3.5. Water saturation distribution for the $200 \mathrm{West}$ Area at $0.1,0.5,1.0$, and $2.0 \mathrm{yr}$ with an infiltration rate of $52 \mathrm{~cm} / \mathrm{d}\left(30 \mathrm{gpm}\right.$ over an area of $\left.314 \mathrm{~m}^{2}\right)$ 

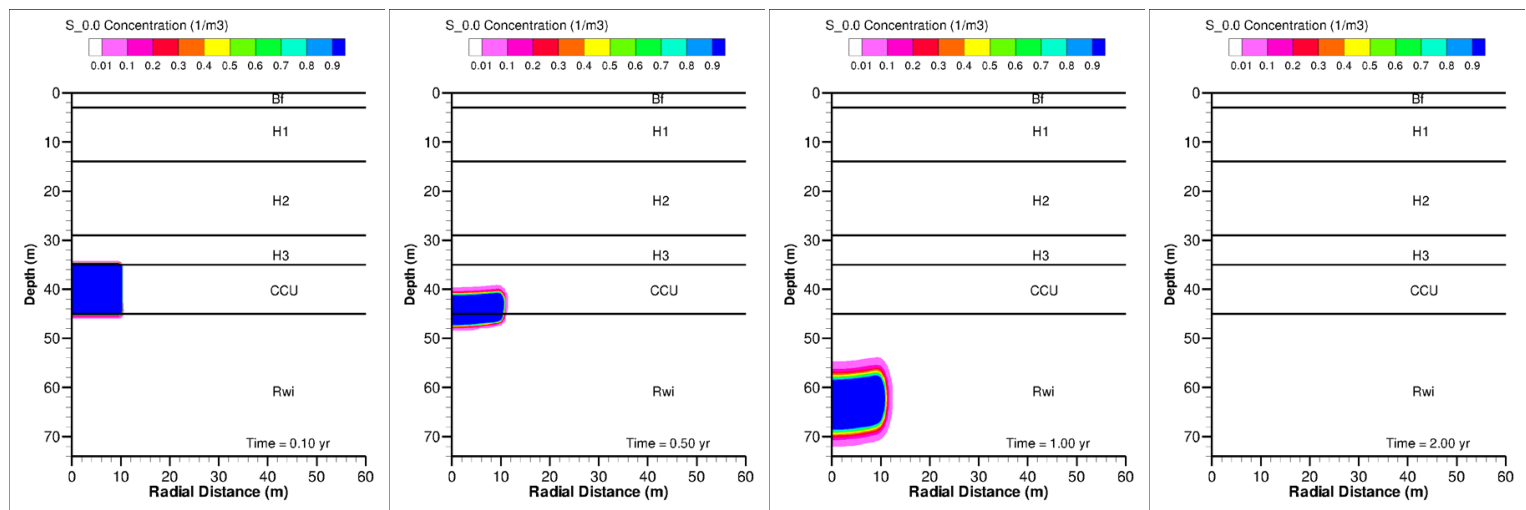

Figure 3.6. Distribution of the aqueous concentration in the 200 West Area for the conservative (non-sorbing) contaminant for at $0.1,0.5,1.0$, and $2.0 \mathrm{yr}$ with an infiltration rate of $52 \mathrm{~cm} / \mathrm{d}$ (30 gpm over an area of $314 \mathrm{~m}^{2}$ )
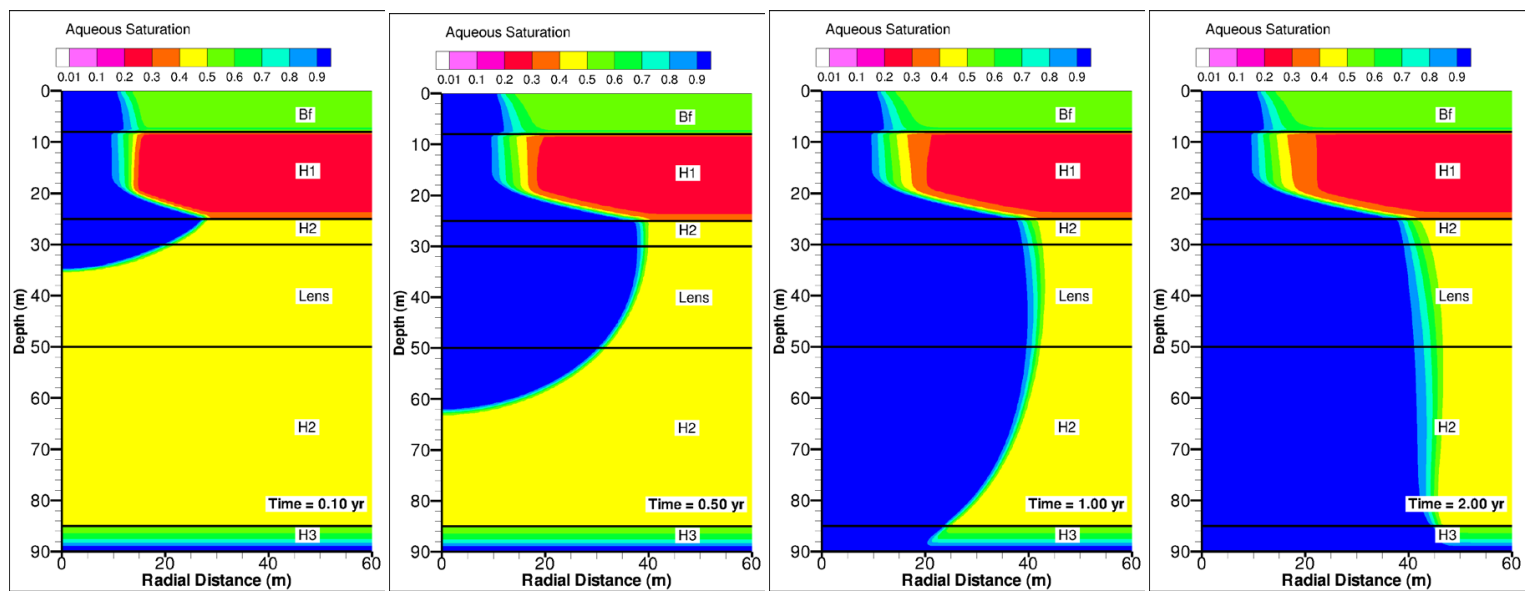

Figure 3.7. Water saturation distribution for the 200 East Area at $0.1,0.5,1.0$, and $2.0 \mathrm{yr}$ with an infiltration rate of $52 \mathrm{~cm} / \mathrm{d}\left(30 \mathrm{gpm}\right.$ over an area of $\left.314 \mathrm{~m}^{2}\right)$
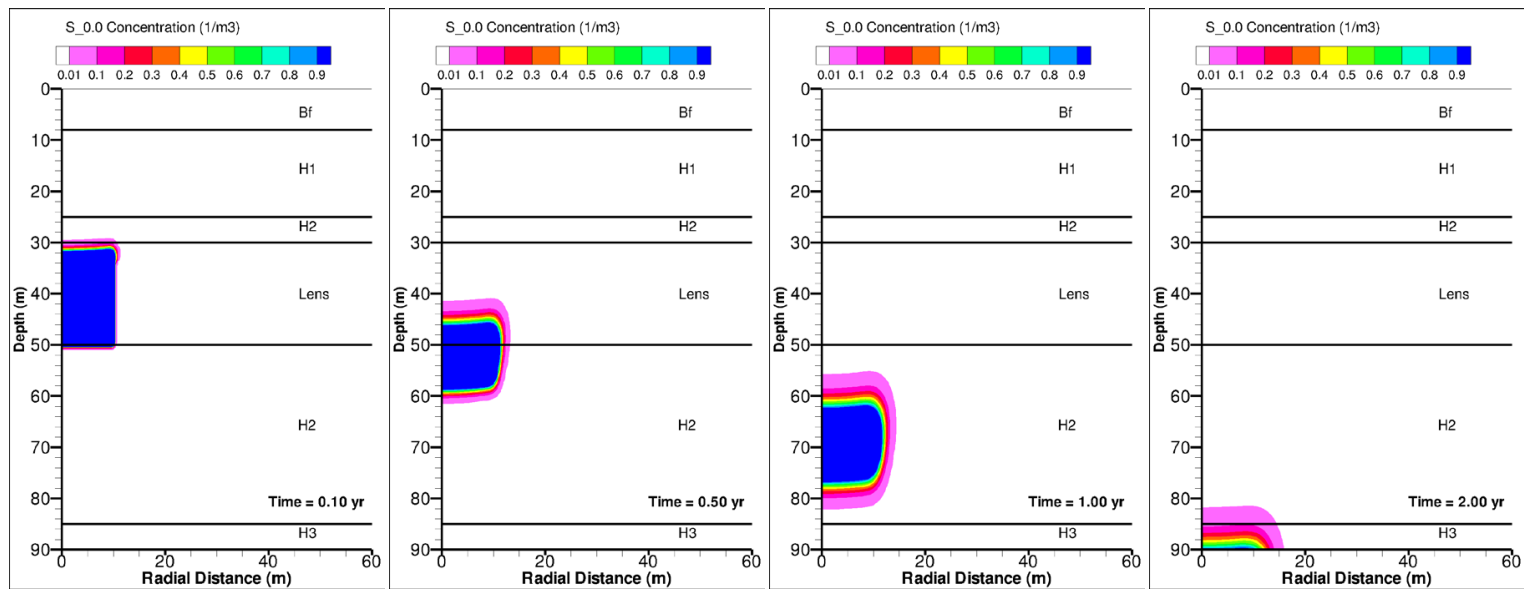

Figure 3.8. Distribution of the aqueous concentration in the 200 East Area for the conservative (nonsorbing) contaminant for at $0.1,0.5,1.0$, and $2.0 \mathrm{yr}$ with an infiltration rate of $52 \mathrm{~cm} / \mathrm{d}$ (30 gpm over an area of $\left.314 \mathrm{~m}^{2}\right)$ 


\subsubsection{Impacts of Infiltration Rate}

The impacts of infiltration rate through the 10-m radius infiltration area were investigated with simulation set I, which includes four simulation cases. Figure 3.9 shows the simulated soil water saturation contour for the $200 \mathrm{West}$ Area at 2 years under different infiltration rates. When the infiltration rate was decreased (from Case [a] to Case [d]), as expected the wetted area by the flushing water became smaller because less water entered the soil at a given time. Figure 3.10 illustrates the simulated aqueous concentration of the conservative contaminant before the plume entered the groundwater table in the 200 West Area. When the infiltration rate was reduced to half, the travel time was increased slightly (by about 0.2 year; Figure $3.10 \mathrm{a}, \mathrm{b}$ ). When the infiltration rate was reduced by a factor of 10 (Figure 3.10c) or 100 (Figure 3.10d), the plume movement was not only slowed down, but its shape was changed as well because the flow was different at different radial distances within the plume.

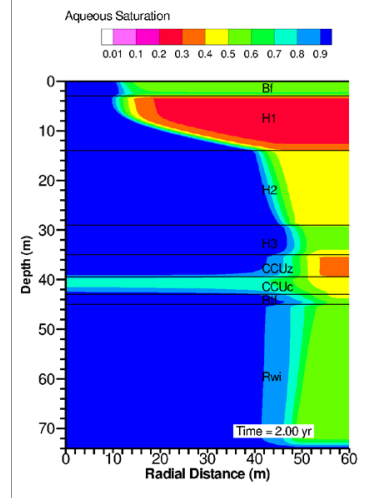

(a) $\mathrm{q}=1 \mathrm{q}_{0}$

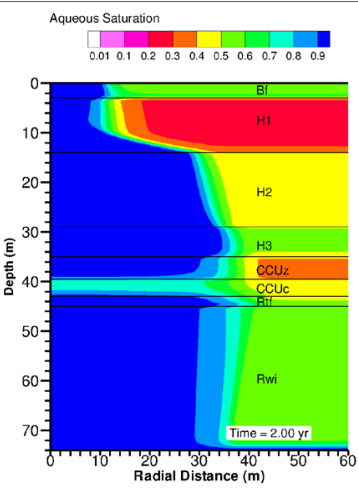

(b) $q=0.5 q_{0}$

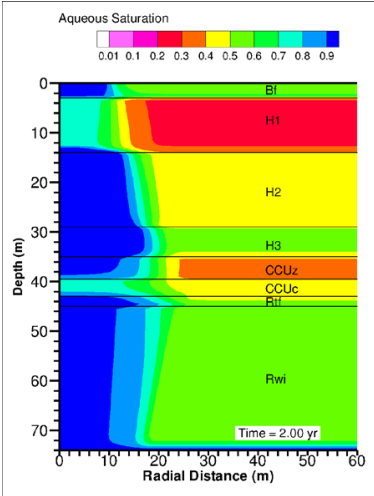

(c) $\mathrm{q}=0.1 \mathrm{q}_{0}$

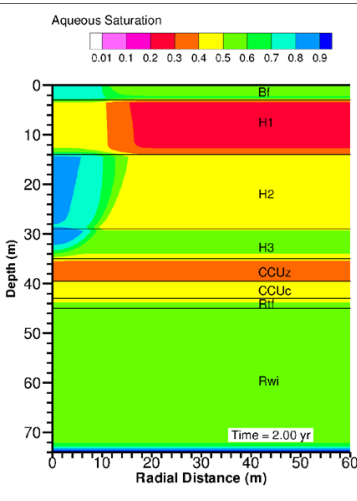

(d) $q=0.01 q_{0}$

Figure 3.9. Simulated soil water saturation for the 200 West Area at 2 yrs for different infiltration rates. The parameter "q" is the infiltration rate from the pond and $\mathrm{q}_{0}$ is the base case infiltration rate of $52 \mathrm{~cm} / \mathrm{d}\left(30 \mathrm{gpm}\right.$ over an area of $\left.314 \mathrm{~m}^{2}\right)$.

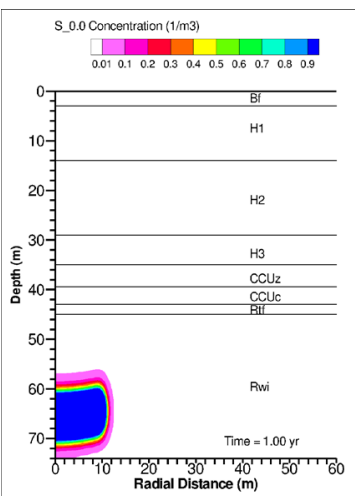

(a) $\mathrm{q}=1 \mathrm{q}_{0}$

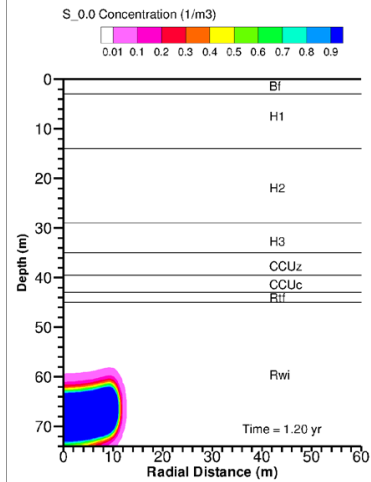

(b) $q=0.5 q_{0}$

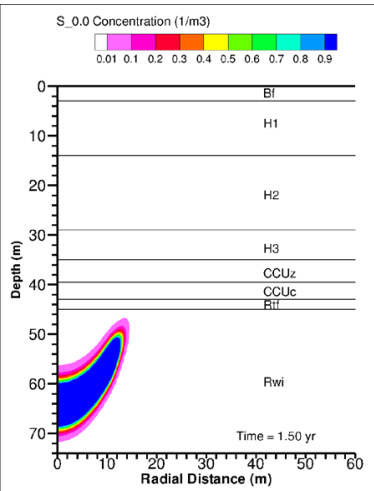

(c) $q=0.1 q_{0}$

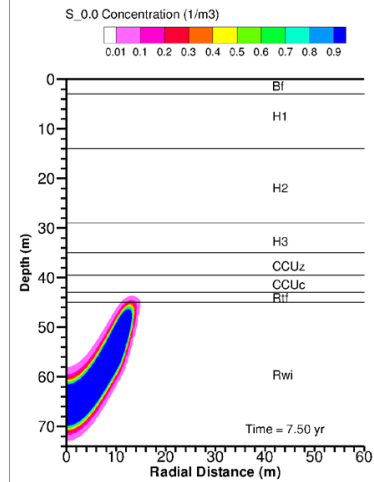

(d) $\mathrm{q}=0.01 \mathrm{q}_{0}$

Figure 3.10. Simulated aqueous concentration of the conservative (non-sorbing) contaminant at different infiltration rates in the 200 West Area. The parameter "q" is the infiltration rate from the pond and $\mathrm{q}_{0}$ is the base case infiltration rate of $52 \mathrm{~cm} / \mathrm{d}\left(30\right.$ gpm over an area of $\left.314 \mathrm{~m}^{2}\right)$. 
For the 200 East Area, Figure 3.11 shows the simulated soil water saturation contour at 2 years for different infiltration rates. Figure 3.12 demonstrates the simulated aqueous concentration of the conservative contaminant before the plume entered the groundwater table. The impacts of infiltration rate for the 200 East Area were similar to those for the 200 West Area.

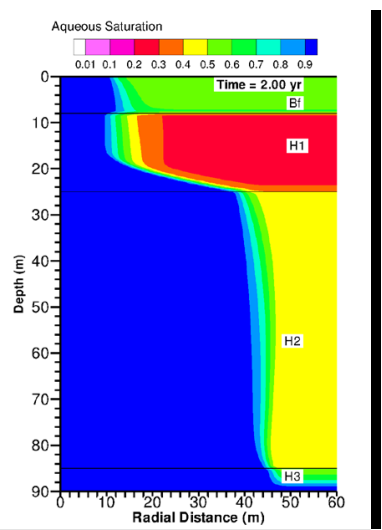

(a) $\mathrm{q}=1 \mathrm{q}_{0}$

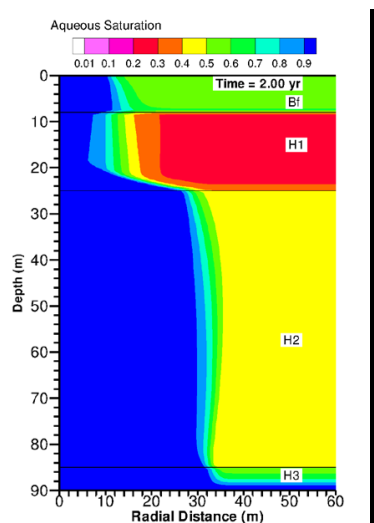

(b) $\mathrm{q}=0.5 \mathrm{q}_{0}$

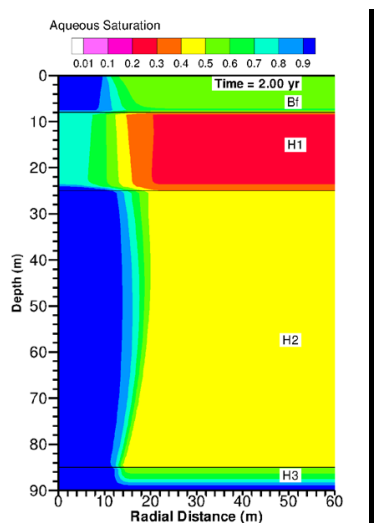

(c) $\mathrm{q}=0.1 \mathrm{q}_{0}$

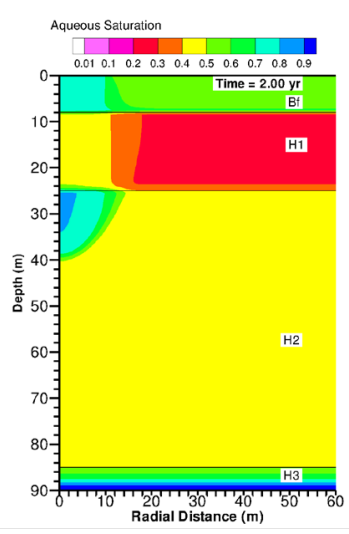

(d) $\mathrm{q}=0.01 \mathrm{q}_{0}$

Figure 3.11. Simulated soil water saturation for the 200 East Area at 2 yrs for different infiltration rates. The parameter " $\mathrm{q}$ " is the infiltration rate from the pond and $\mathrm{q}_{0}$ is the base case infiltration rate of $52 \mathrm{~cm} / \mathrm{d}\left(30\right.$ gpm over an area of $\left.314 \mathrm{~m}^{2}\right)$.

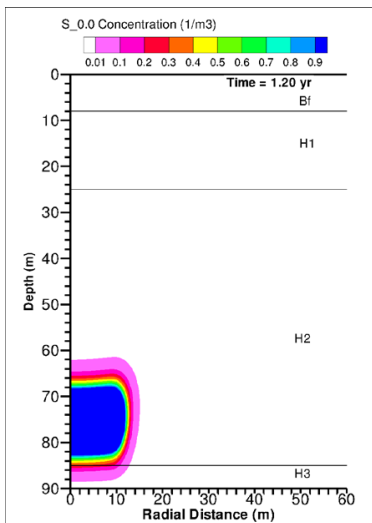

(a) $\mathrm{q}=1 \mathrm{q}_{0}$

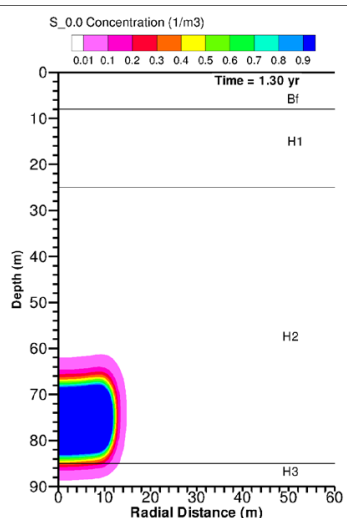

(b) $q=0.5 q_{0}$

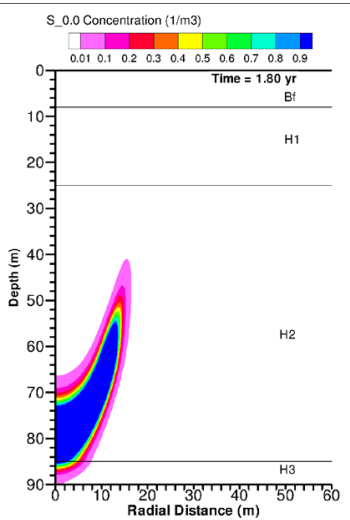

(c) $\mathrm{q}=0.1 \mathrm{q}_{0}$

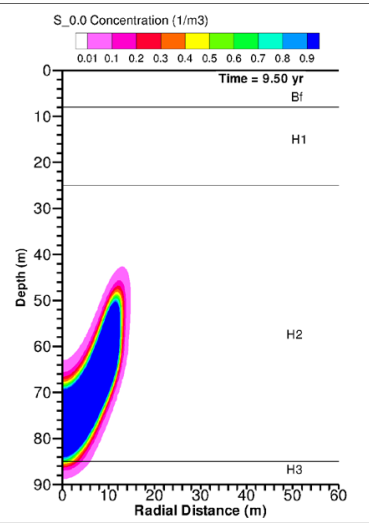

(d) $q=0.01 q_{0}$

Figure 3.12. Simulated aqueous concentration of the conservative (non-sorbing) contaminant at different infiltration rates in the 200 East Area. The parameter "q" is the infiltration rate from the pond and $\mathrm{q}_{0}$ is the base case infiltration rate of $52 \mathrm{~cm} / \mathrm{d}\left(30\right.$ gpm over an area of $\left.314 \mathrm{~m}^{2}\right)$.

\subsubsection{Impacts of Conductivity and Layer Thickness}

There were 16 simulation cases conducted to investigate the impacts of conductivity and layer thickness on soil flushing technology for the 200 West Area and 200 East Area. Figure 3.13 shows the simulated aqueous saturation at 2 years in the 200 West Area for these 16 cases. When the CCU conductivity was reduced (different columns from left to right in Figure 3.13), there was a stronger lateral movement of flow. Note that the base case conductivity for the CCU is higher than the surrounding units (2.9 times higher than the overlying layer). When the CCU thickness was reduced (different rows from top to bottom in Figure 3.13), the impact of CCU conductivity on flow became smaller. The impacts of CCU-saturated hydraulic conductivity and thickness on lateral flow are quantified by the percentage of 
cumulative aqueous volume across the vertical plane of radius $r=50 \mathrm{~m}$ over the total injected volume (Figure 3.14). When the ratio of the saturated hydraulic conductivity of the CCU to the hydraulic conductivity of the surrounding units was less than 1 , the lateral flow becomes significant. At a conductivity ratio of 0.029 , lateral flow was a maximum of $57.6 \%$ when the CCU layer was the thickest $(10 \mathrm{~m})$ and $8.6 \%$ when the layer was the thinnest $(0.1 \mathrm{~m})$.

Figure 3.15 demonstrates the aqueous concentration of the conservative contaminant at 2 years in the 200 West Area. When the CCU conductivity was reduced (different columns from left to right in Figure 3.15), the vertical transport of contaminants is slowed down. When the CCU thickness was reduced (different rows from top to bottom in Figure 3.15), the impact of CCU conductivity on transport became smaller. There was very little lateral transport under all simulation conditions. The percent of contaminant transport across the plane of radius $\mathrm{r}=10 \mathrm{~m}$ (the initial plume radius) at 2 years ranged from $3.7 \%$ to $10.2 \%$.

Figure 3.16 shows the simulated aqueous saturation at 2 years in the 200 East Area for the 16 cases. Figure 3.17 illustrates the percentage of cumulative aqueous volume across the vertical plane of radius $\mathrm{r}=50 \mathrm{~m}$ over the total injected volume. Figure 3.18 depicts the aqueous concentration of the conservative contaminant at 2 years in the 200 East Area. The impacts of the silt lens conductivity and thickness were very similar to those for the 200 West Area.

The above results indicate that lateral flow becomes a significant fraction of the infiltration flow when the CCU/silt lens hydraulic conductivity is lower than the hydraulic conductivity of surrounding material (i.e., ratios of less than 1) and is more significant as the CCU/silt lens thickness increases. In portions of the 200 West Area with a relatively thick low-permeability CCU, or if a thick silt zone were present in the 200 East Area, significant lateral water movement would be expected. For a specific site, the thickness and permeability of a silt layers/lenses should be considered in light of these simulation results to determine the expected extent of lateral water movement during soil flushing. Lateral contaminant movement is limited for the imposed contaminant zones in the model, which are vertically beneath the infiltration area at the surface. Contaminants distributed elsewhere may experience some lateral movement, but this situation was not quantified in the simulations. 

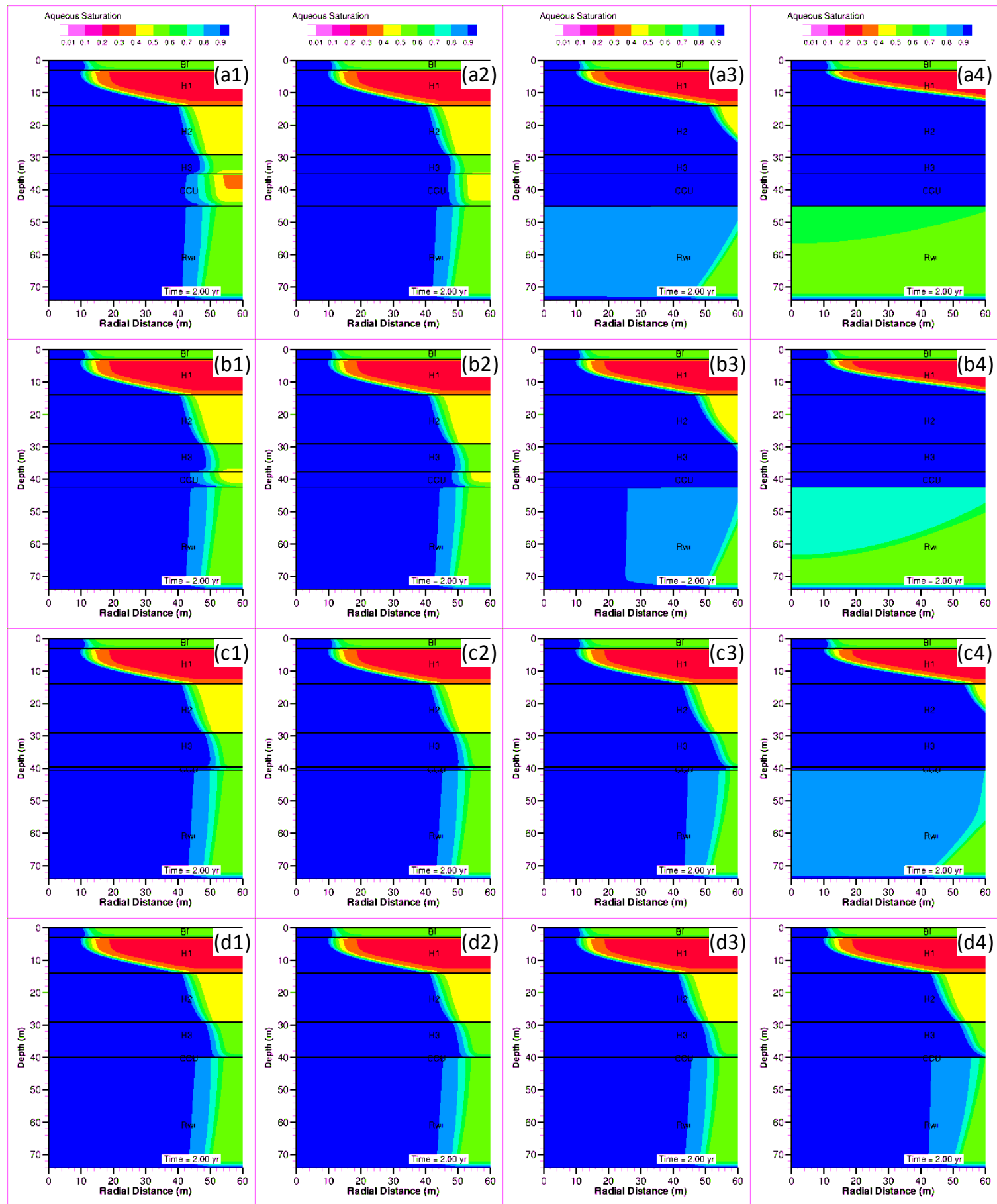

Figure 3.13. Simulated aqueous saturation at 2 yrs in the 200 West Area. Rows a, b, c, and d correspond to the CCU thicknesses variation factors $\mathrm{f}_{\mathrm{d}}$ of $1,0.5,0.1$, and $0.01 \mathrm{~m}$, respectively.

Columns $1,2,3$, and 4 correspond to CCU conductivity ratios $\left(\mathrm{K}_{\mathrm{s}-\mathrm{CCU}} / \mathrm{K}_{\text {s-overlying }}\right)$ of $2.9,1.5$, 0.29 , and 0.029 , respectively. 


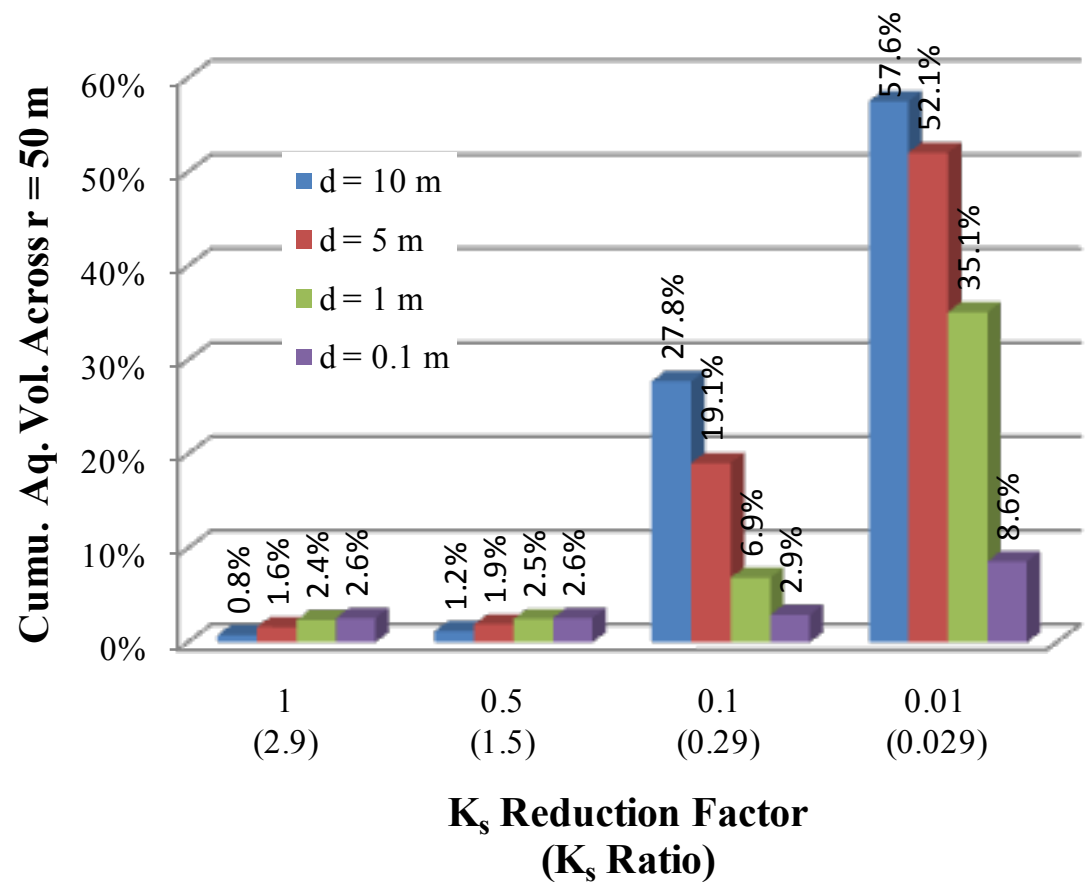

Figure 3.14. Percentage of cumulative aqueous volume across a vertical plane at radius $r=50 \mathrm{~m}$ for the total injected volume after 2 yrs in the 200 West Area. Variations tested include the thickness (d) and the hydraulic conductivity $\left(\mathrm{K}_{\mathrm{s}}\right)$ of the CCU. Variations in $\mathrm{K}_{\mathrm{s}}$ result in a different ratio of hydraulic conductivity between the $\mathrm{CCU}$ and the surrounding material. The $\mathrm{K}_{\mathrm{s}}$ ratio values in parentheses show the ratio of CCU hydraulic conductivity to the hydraulic conductivity of the porous media just above the CCU. 

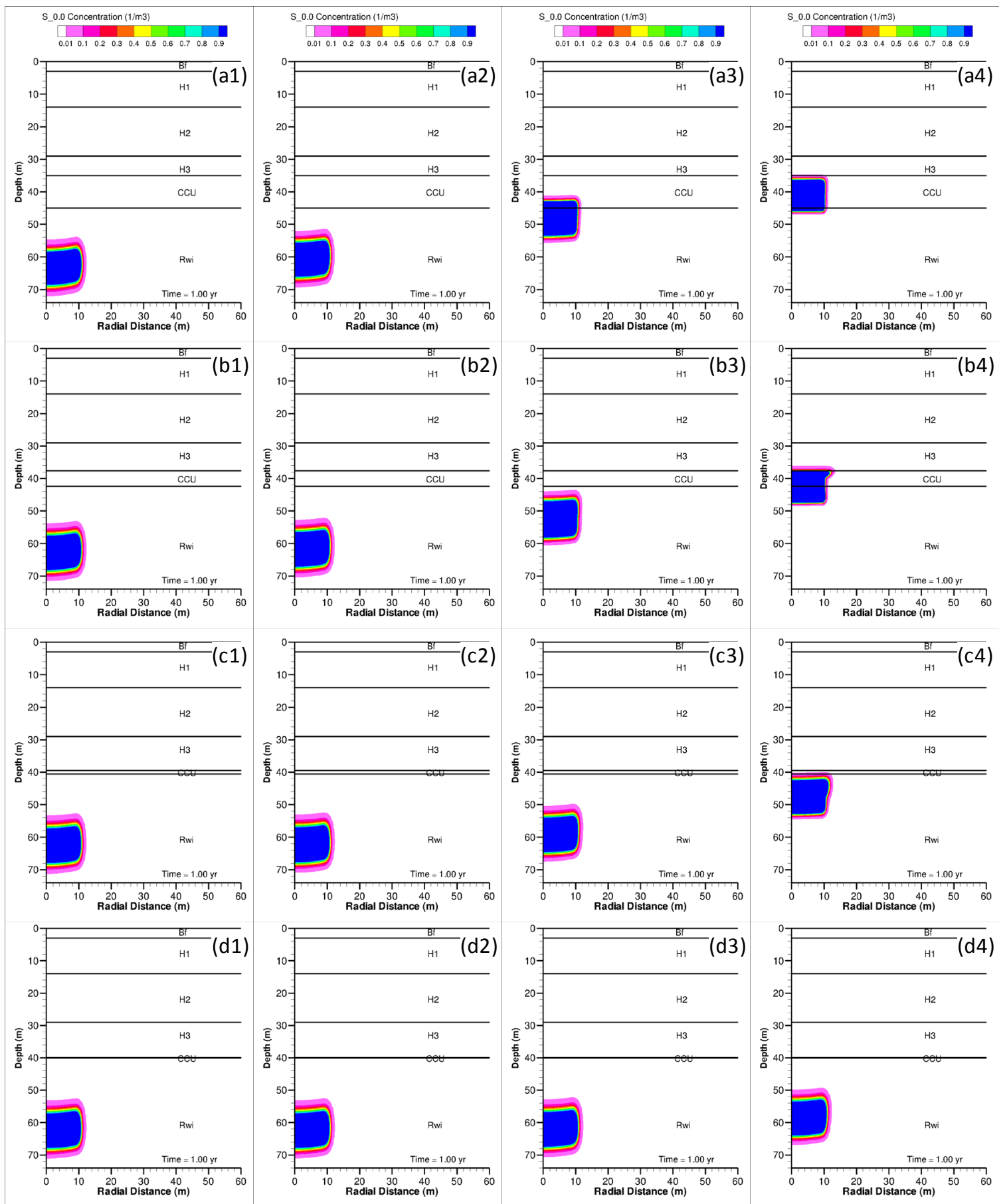

Figure 3.15. Simulated aqueous concentration of the conservative (non-sorbing) contaminant at 2 yrs in the 200 West Area. Rows a, b, c, and d correspond to the CCU thicknesses variation factors $\mathrm{f}_{\mathrm{d}}$ of $1,0.5,0.1$, and $0.01 \mathrm{~m}$, respectively. Columns $1,2,3$, and 4 correspond to CCU conductivity ratios ( $\left.\mathrm{K}_{\mathrm{s}-\mathrm{CCU}} / \mathrm{K}_{\mathrm{s} \text {-overlying }}\right)$ of $2.9,1.5,0.29$, and 0.029 , respectively. 


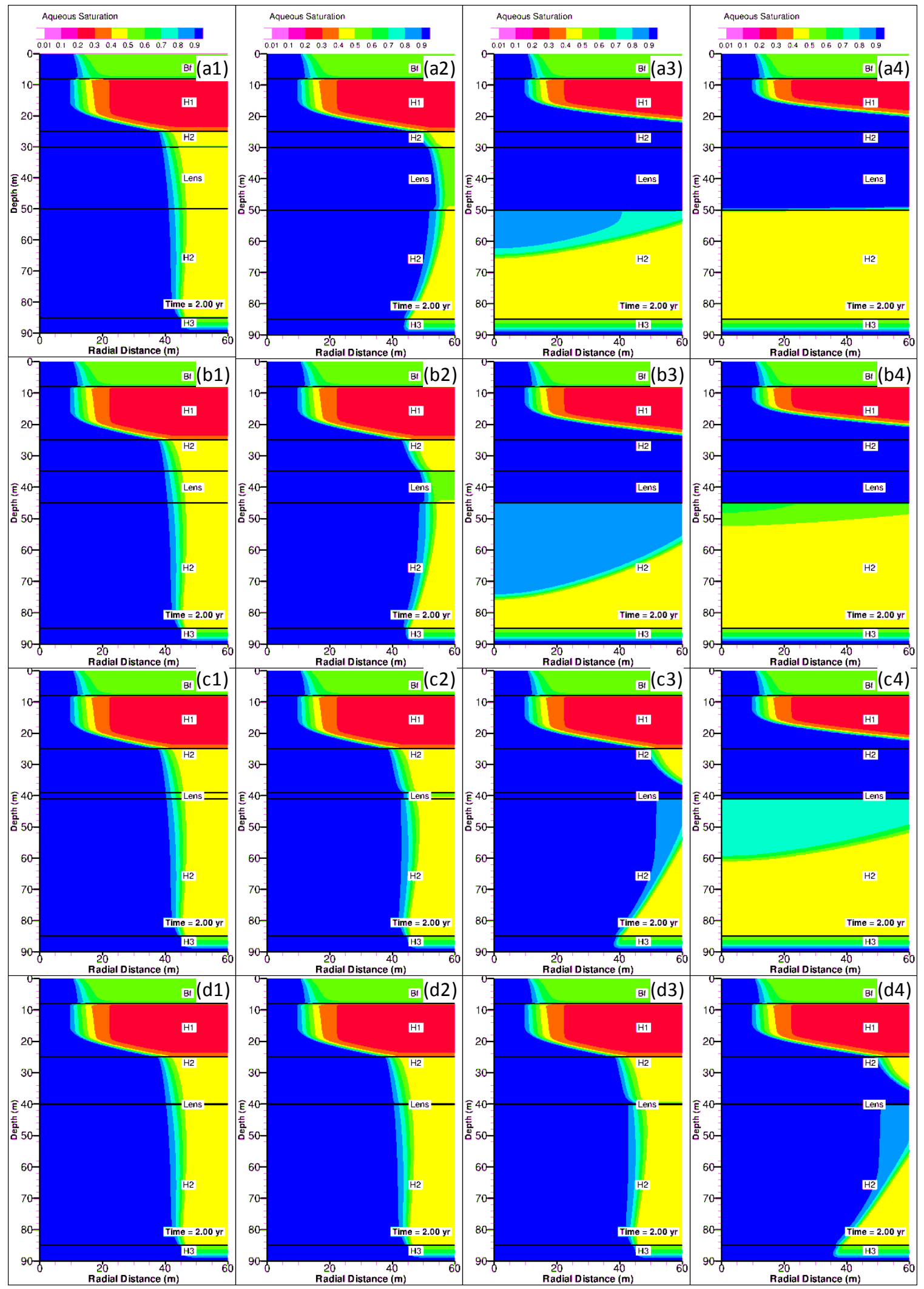

Figure 3.16. Simulated aqueous saturation at 2 yrs in the 200 East Area. Rows a, b, c, and d correspond to the imposed silt lens thicknesses variation factors $f_{d}$ of $1,0.5,0.1$, and $0.01 \mathrm{~m}$, respectively. Columns $1,2,3$, and 4 correspond to silt lens conductivity ratios $\left(\mathrm{K}_{\mathrm{s}}\right.$-silt/ $\mathrm{K}_{\mathrm{s}}$-overlying) of $1,0.5,0.1$, and 0.01 , respectively. 


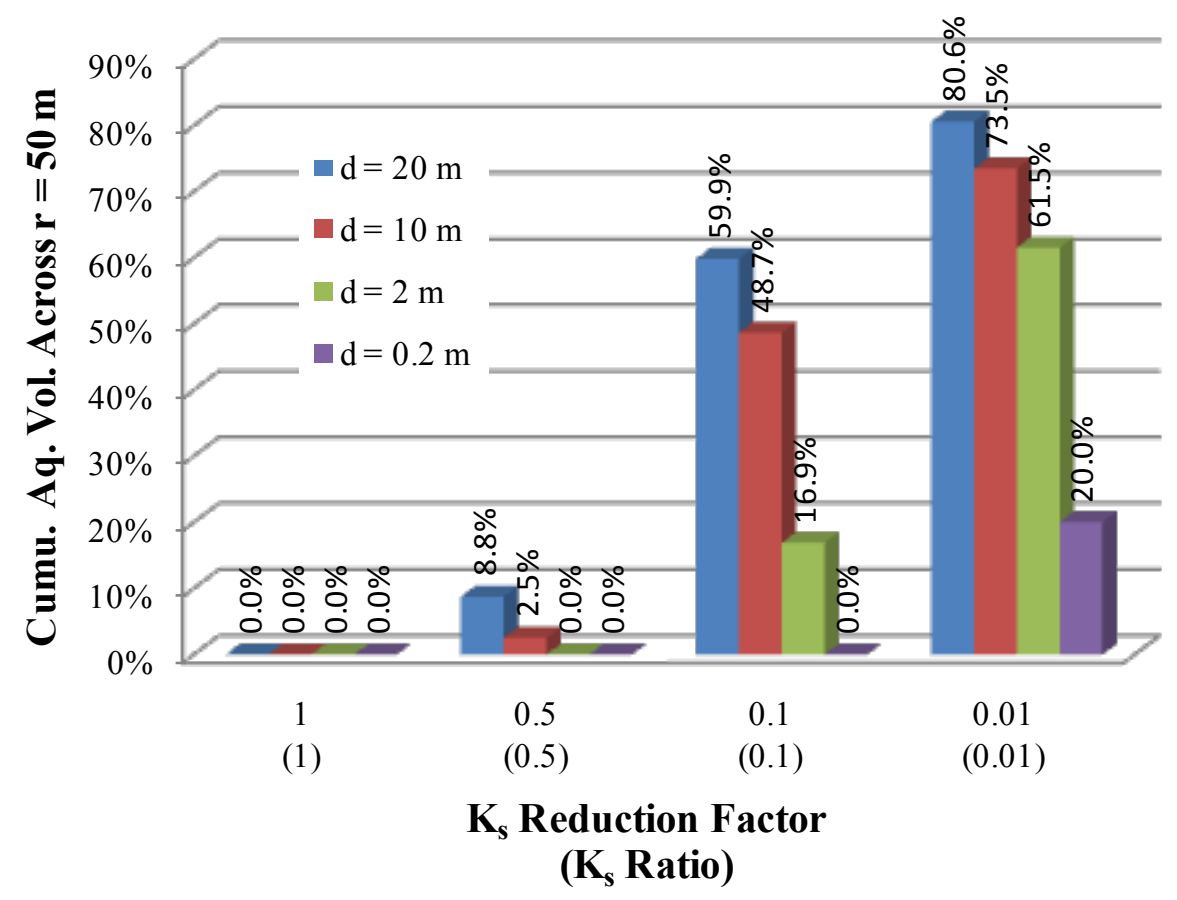

Figure 3.17. Percentage of cumulative aqueous volume across a vertical plane at radius $r=50 \mathrm{~m}$ for the total injected volume after 2 yrs for the 200 East Area. Variations tested include the thickness (d) and the hydraulic conductivity $\left(\mathrm{K}_{\mathrm{s}}\right)$ of the imposed $\mathrm{H} 2$ silt lens. Variations in $\mathrm{K}_{\mathrm{s}}$ result in a different ratio of hydraulic conductivity between the imposed $\mathrm{H} 2$ silt lens and the surrounding material. The $\mathrm{K}_{\mathrm{s}}$ ratio values in parentheses show the ratio of imposed $\mathrm{H} 2$ silt lens hydraulic conductivity to the hydraulic conductivity of the porous media just above the imposed $\mathrm{H} 2$ silt lens. 

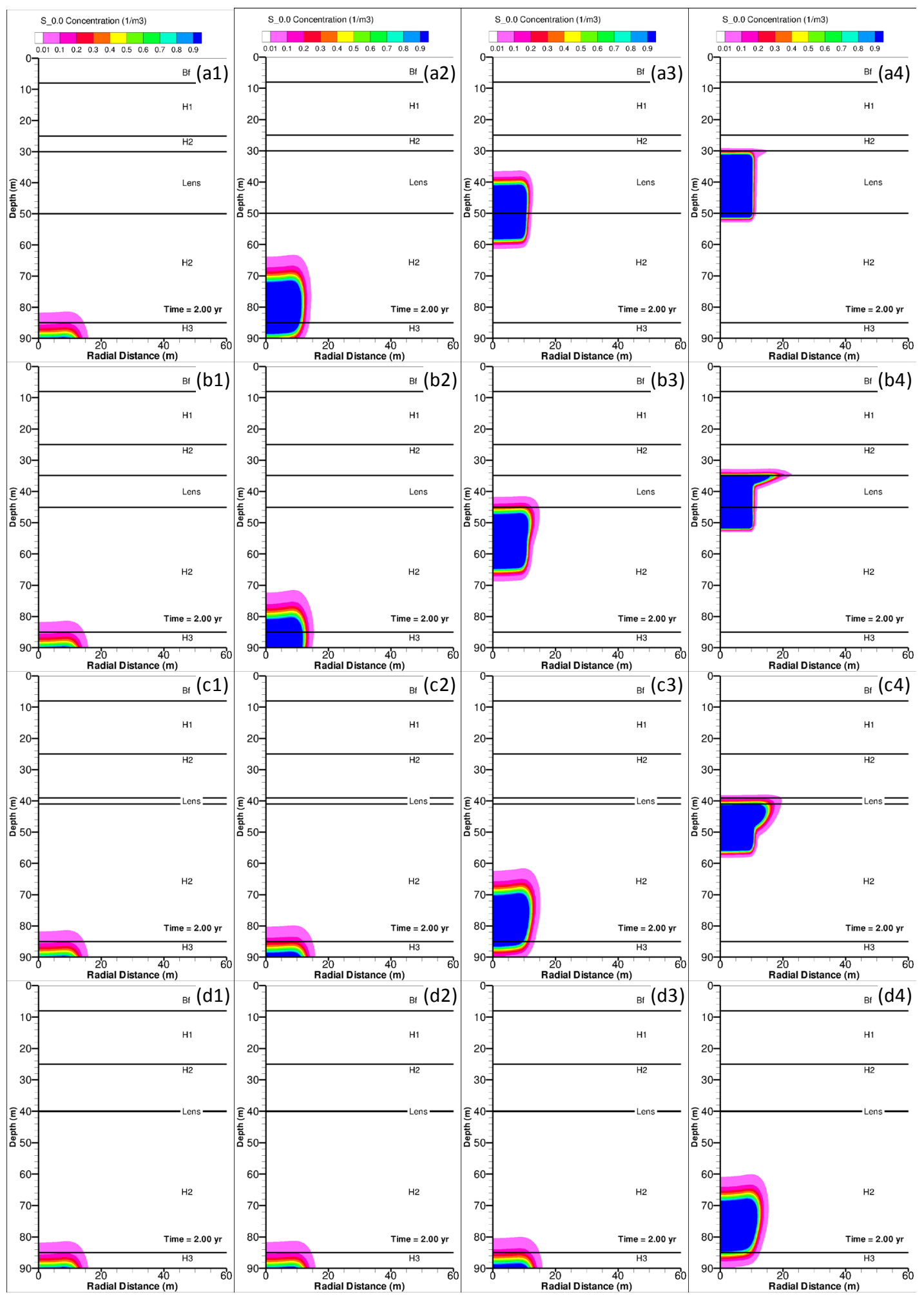

Figure 3.18. Simulated aqueous concentration of the conservative (non-sorbing) contaminant at 2 yrs in the 200 East Area. Rows a, b, c, and d correspond to the imposed silt lens thicknesses variation factors $\mathrm{f}_{\mathrm{d}}$ of $1,0.5,0.1$, and $0.01 \mathrm{~m}$, respectively. Columns $1,2,3$, and 4 correspond to silt lens conductivity ratios $\left(\mathrm{K}_{\mathrm{s}-\text { silt }} / \mathrm{K}_{\text {s-overlying }}\right)$ of $1,0.5,0.1$, and 0.01 , respectively. 


\subsubsection{Impact of Fluid Properties}

The impact of fluid properties on soil flushing was investigated by increasing the fluid density by 5\% or decreasing the fluid viscosity by $20 \%$, or imposing both variations at the same time. The infiltration rate was maintained as equal to the hydraulic conductivity of the top layer $(52 \mathrm{~cm} / \mathrm{d})$ for all fluids. Figure 3.19 shows the fluid saturation at 2 years for the 200 West Area. The lateral movement of flow was decreased slightly when either the fluid density was increased or the viscosity was decreased. Figure 3.20 illustrates the cumulative aqueous volume into the groundwater vertically beneath the infiltration area. The vertical movement of flow increased slightly when either the fluid density was increased or the viscosity was decreased. It is expected the surface tension of the flushing fluid could have an impact on soil flushing effectiveness. At the time the investigation was conducted, the capability to simulate the movement of a flushing fluid with varying surface tension was not available. Hence, no results are available on this factor.

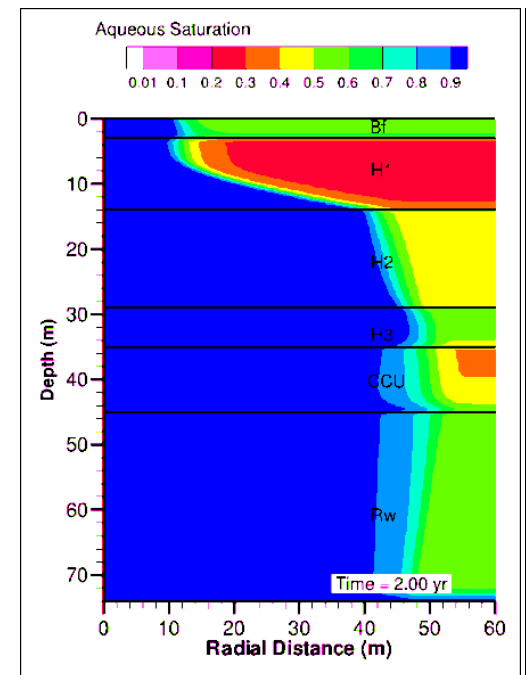

(a) $f_{\rho}=1, f_{v}=1$

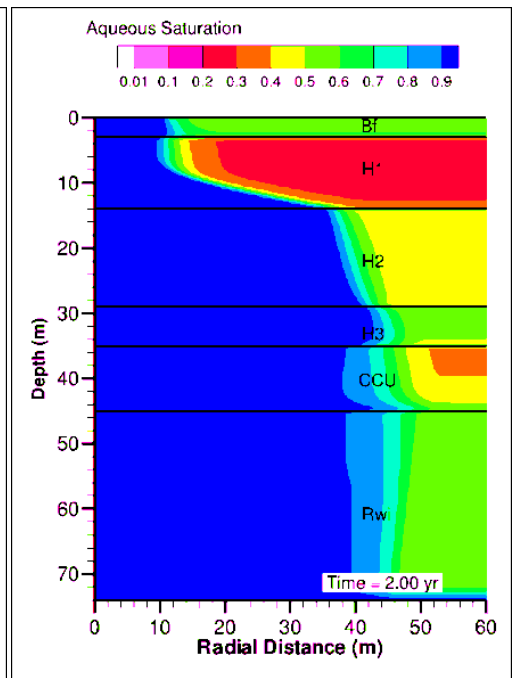

(b) $f_{\rho}=1, f_{v}=0.8$

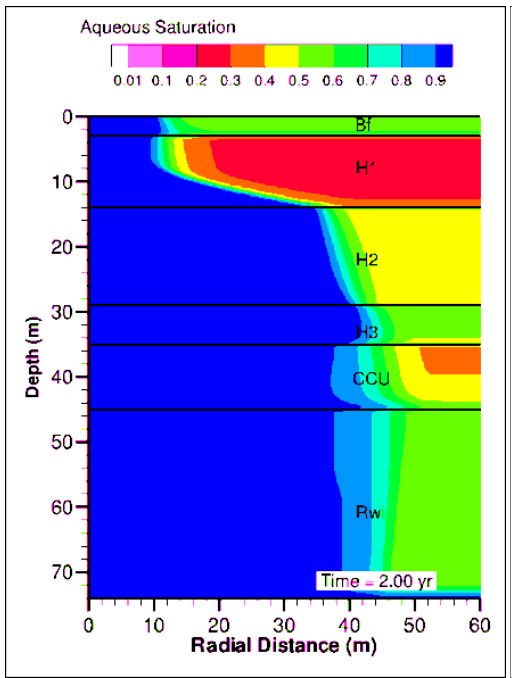

(a) $f \rho=105, f v=1$

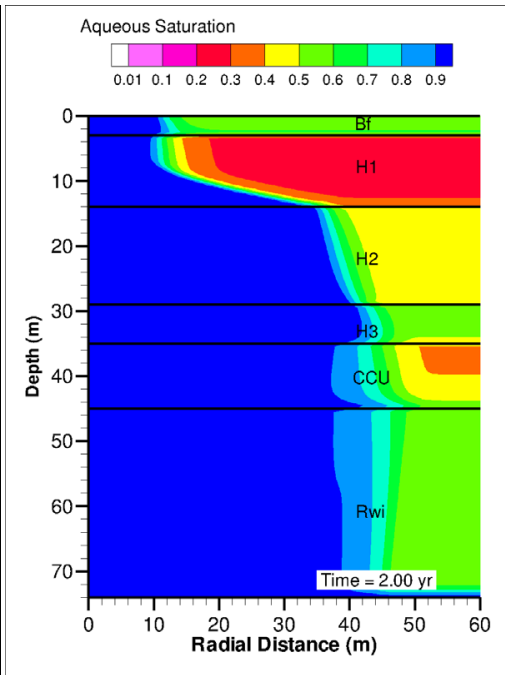

(b) $\mathrm{f} \rho=1.05, \mathrm{fv}=0.8$

Figure 3.19. Saturation distributions for variations in flushing fluid density and viscosity 


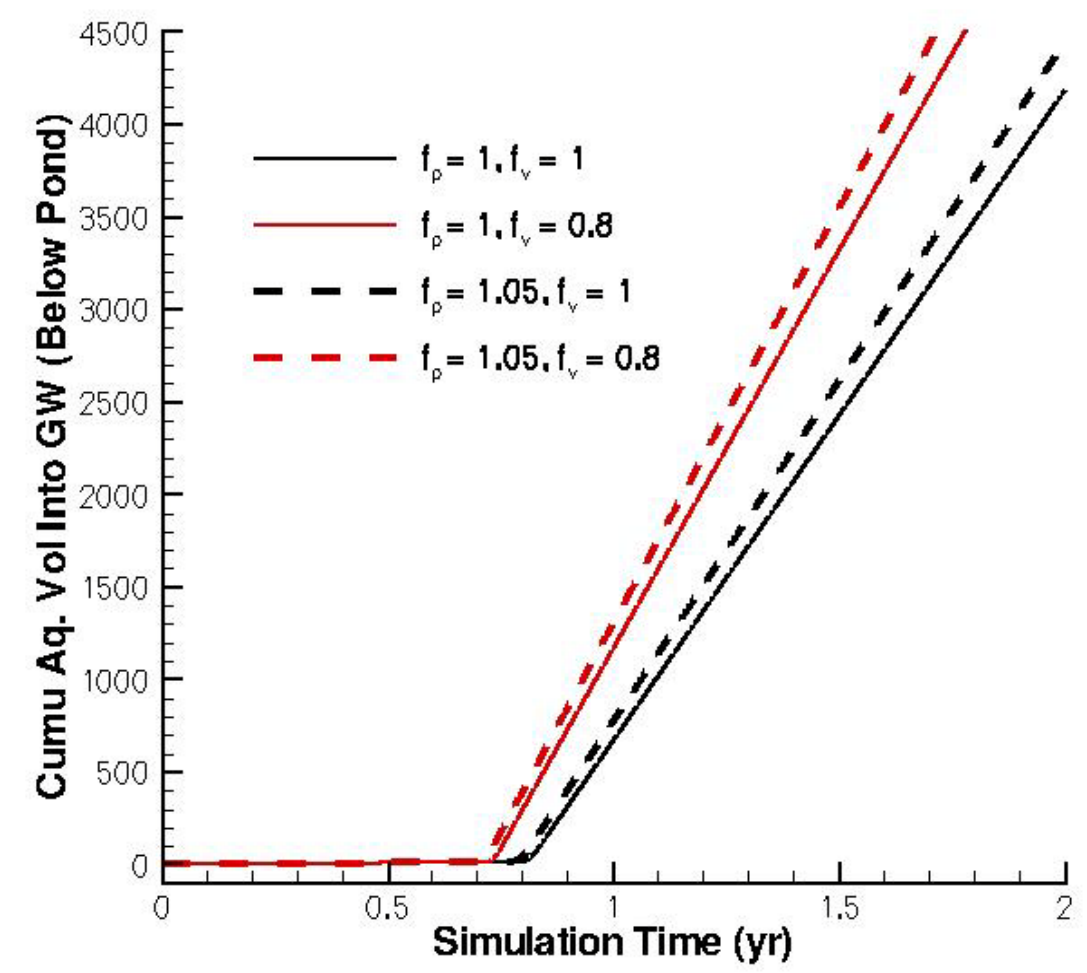

Figure 3.20. Cumulative aqueous volume into the groundwater vertically beneath the infiltration area. The parameter $f_{p}$ is the fluid density in units of $\mathrm{g} \mathrm{cm}^{-3}$. The parameter $\mathrm{f}_{\mathrm{v}}$ is the fluid viscosity in units of $\mathrm{cP}$.

\subsubsection{Impact of Sorption}

The simulated transport velocity of sorbing contaminants is slower than the velocity of the flushing fluid. The retardation factor $\mathrm{R}$ is used to represent this difference in contaminant and water velocity. The value of $\mathrm{R}$ is related to the sorption coefficient, $\mathrm{k}_{\mathrm{d}}$, by Equation (1.1):

$$
\mathrm{R}=1+\mathrm{k}_{\mathrm{d}} \rho_{\mathrm{b}} / \theta
$$

where $\rho_{b}$ is the bulk density and $\theta$ is the volumetric water content. Assuming that $\theta=0.35 \mathrm{~m}^{3} \mathrm{~m}^{-3}$ and $\rho_{\mathrm{b}}=1.70 \mathrm{~g} \mathrm{~cm}^{-3}$, which are approximately equal to the average values of the CCU and Rwi units, the corresponding $\mathrm{R}$ values are 1.0, 1.5, 2.5, 5.9, 15.6, and 49.6 for contaminants with $\mathrm{k}_{\mathrm{d}}$ of $0,0.1,0.3,1,3$, and $10 \mathrm{~cm}^{3} \mathrm{~g}^{-1}$, respectively. An example of how contaminant transport velocity varies with the value of $\mathrm{k}_{\mathrm{d}}$ is shown in Figure 3.21. The approximate transport velocities, $v$, were 42.5, 25.0, 13.8, 6.3, 1.9, and $0.6 \mathrm{~m} \mathrm{yr}^{-1}$ for the 6 contaminants with $\mathrm{k}_{\mathrm{d}}$ of $0,0.1,0.3,1,3$, and $10 \mathrm{~cm}^{3} \mathrm{~g}^{-1}$, respectively. The ratios between these velocities were nearly proportional to the retardation ratios of corresponding contaminants. This trend was not significantly impacted by the variation of CCU (or silt lens) thickness or conductivity or by the infiltration rate (data not shown). 

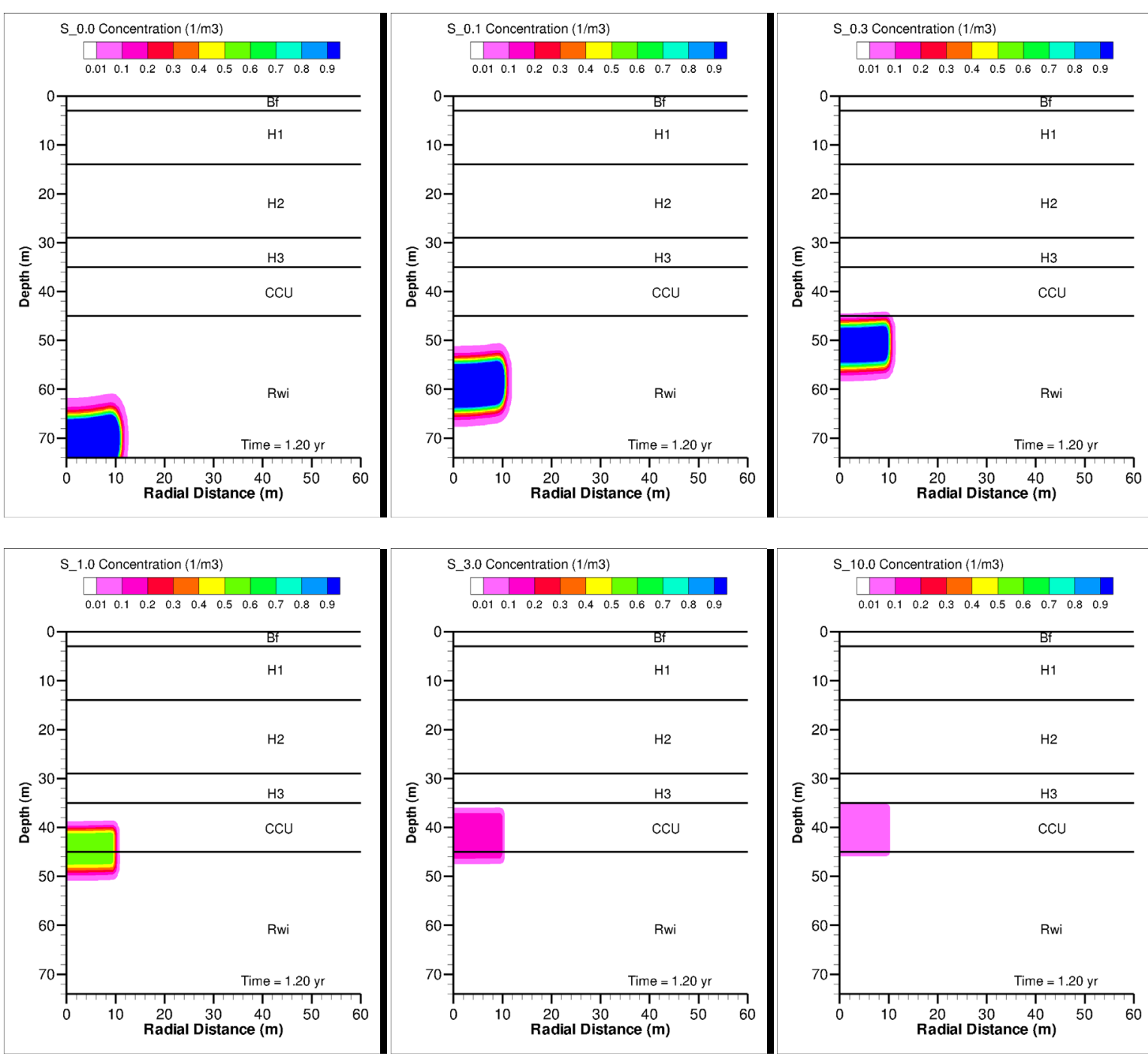

Figure 3.21. The aqueous contaminant concentration in the $200 \mathrm{West}$ Area at $1.2 \mathrm{yr}$ for the base case configuration of simulation set I 


\subsection{Laboratory Study of Water Infiltration and Contaminant Flushing}

Laboratory flow-cell experiments were conducted to demonstrate water infiltration and contaminant flushing as a function of subsurface properties. The experiments were modeled using the same code as was used for the field-scale simulations reported in Section 3.0.

\subsection{Laboratory Experimental Approach}

Two intermediate-scale flow-cell experiments were conducted in a 100-cm-high, 50-cm-long, and 5-cm-wide flow cell. The lower left-hand corner of the flow cell is denoted as $\mathrm{x}=0 \mathrm{~cm}$ and $\mathrm{z}=0 \mathrm{~cm}$. In Experiment I, the cell was filled with Hanford Site lysimeter sand, originally obtained from the Burial Waste Treatment Facility (BWTF). In Experiment II, a 10-cm-long horizontal layer of Warden Silt (WS) was emplaced between $\mathrm{z}=60$ and $\mathrm{z}=70 \mathrm{~cm}$ in an otherwise BWTF matrix. Porous medium and hydraulic property values for both porous media are listed in Table 4.1. The hydraulic conductivity and retention parameters were obtained using the methods described in Wietsma et al. (2009). Both flow-cell experiments were packed with sediments mixed with $75 \mathrm{~g}$ water $/ \mathrm{kg}$ sediments. The average porosity of the packed sediments are listed in Table 4.1.

Table 4.1. Overview of porous medium and hydraulic property values for the Warden Silt and Burial Waste Treatment Facility sediment

\begin{tabular}{lcc}
\hline Porous Medium and Hydraulic Property Values & WS & BWTF \\
\hline Organic carbon content $(\%)$ & 0.807 & 0.35 \\
Surface area $\left(\mathrm{m}^{2} / \mathrm{g}\right)$ & 19.7 & 7.5 \\
Porosity & 0.47 & 0.34 (Exp. I) \\
& & 0.33 (Exp. II) \\
Saturated Hydraulic Conductivity (m/day) & 0.103 & 12.6 \\
Van Genuchten n & 3.2 & 3.0 \\
Van Genuchten $\alpha(1 / \mathrm{cm})$ & 0.012 & 0.084 \\
Irreducible saturation & 0.21 & 0.11 \\
\hline
\end{tabular}

The sediment emplaced in a $10-\mathrm{cm}$ by $10-\mathrm{cm}$ square between $\mathrm{x}=0$ and $\mathrm{x}=10 \mathrm{~cm}$ horizontally and $\mathrm{z}=60$ and $\mathrm{z}=70 \mathrm{~cm}$ vertically (see Figures 4.1 and 4.2) was packed using water mixed with 200 parts per million (ppm) KBr and 1000 ppm Na2HPO4 as tracers. The bromide anion (Br-) is considered to be a conservative (nonsorbing) tracer representative of how technetium would respond to a flushing solution. Phosphate will be considerably retarded by both sediments and was added to evaluate whether the test conditions imposed any movement of contaminant significantly faster than expected based on soil partitioning.

Configurations of the two packings with the initial contaminated zones are shown in Figures 4.1 and 4.2 , respectively. After packing was completed, water was injected at a rate of $5 \mathrm{~mL} / \mathrm{min}$ from an inlet port located at $\mathrm{x}=0 \mathrm{~cm}$ and $\mathrm{z}=5 \mathrm{~cm}$. A constant water table was maintained at the other side of the flow cell at $\mathrm{x}=50$ and $\mathrm{z}=2 \mathrm{~cm}$. 


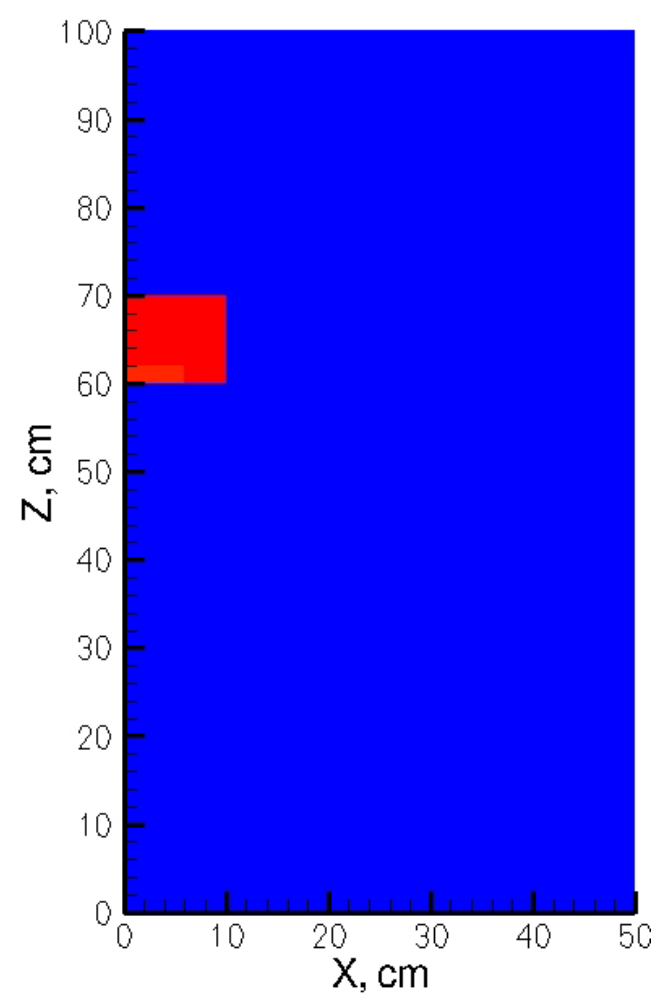

Figure 4.1. Schematic for Experiment I with the initially contaminated zone in red

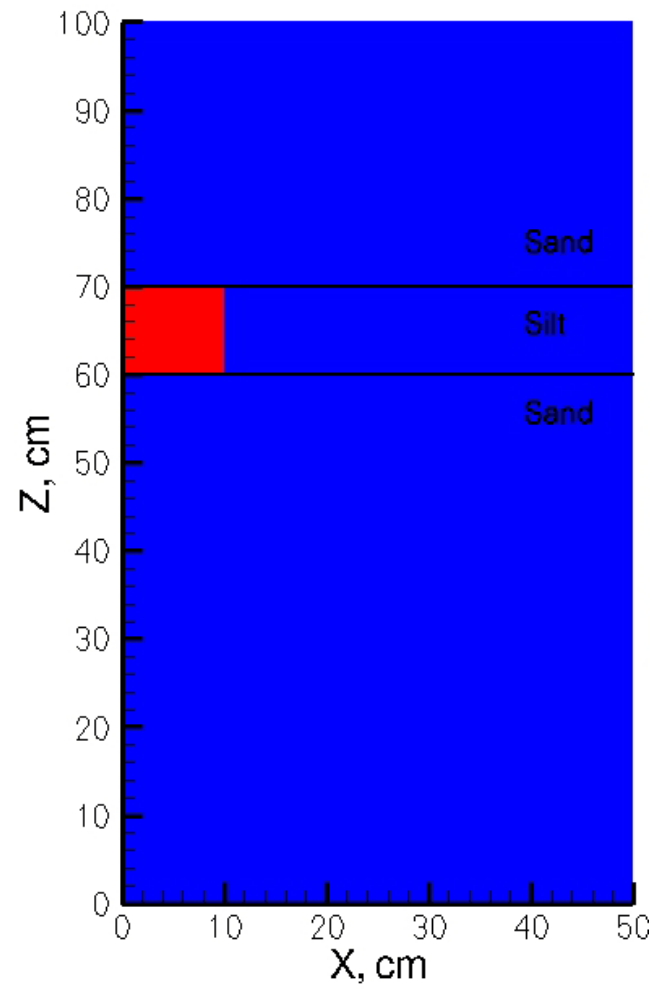

Figure 4.2. Schematic of Experiment II with the initially contaminated zone in red 
The horizontal water injection was continued at least 1 day after steady state was obtained. Surface soil flushing was then initiated by injection from four injection points at the top of the flow cell with $1.25 \mathrm{~mL} / \mathrm{min}$ each for a total of $5 \mathrm{~mL} / \mathrm{min}$. The injection ports are located at $\mathrm{x}=1.25,3.75,6.25$, and $8.75 \mathrm{~cm}$, respectively. Water was injected for a total of 120 hours, for a cumulative volume of $36 \mathrm{~L}$. A dual-energy gamma scanner (Oostrom et al. 1998) was used to obtain a steady-state water saturation during the final day of injection. Effluent samples were obtained every 30 minutes during the first 12 hours, hourly from 12 to 24 hours, and after that every 8 hours.

\subsection{Model Configuration}

The experiments were simulated using the water mode of the STOMP (White and Oostrom 2006) code. The porous medium and hydraulic input parameters are listed in Table 4.1. The 100- $\mathrm{x} 50-\mathrm{x} 5-\mathrm{cm}$ domain was discretized in $1-\mathrm{x} 1-\mathrm{x} 5$-cm grid blocks for a total of 5000 cells. Neumann boundary conditions are used for the horizontal and top injection locations. For the homogeneous experiment (Experiment I), besides the base case simulation, eight sensitivity simulations were completed. A list of these simulations is provided in Table 4.2 .

Table 4.2. Overview of hydraulic parameter values for the base case and sensitivity simulations

\begin{tabular}{lcccc}
\hline & $\mathrm{K}_{\text {sat }}(\mathrm{m} /$ day $)$ & Porosity & Van Genuchten $\mathrm{n}$ & $\begin{array}{c}\text { Van Genuchten } \\
\text { alpha }(1 / \mathrm{cm})\end{array}$ \\
\cline { 2 - 5 } \multicolumn{1}{c}{ Base Case } & 12.6 & 0.34 & 3.0 & 0.084 \\
\hline Simulation 1 & 126 & 0.34 & 3.0 & 0.084 \\
Simulation 2 & 1.26 & 0.34 & 3.0 & 0.084 \\
Simulation 3 & 12.6 & 0.379 & 3.0 & 0.084 \\
Simulation 4 & 12.6 & 0.255 & 3.0 & 0.084 \\
Simulation 5 & 12.6 & 0.34 & 2.0 & 0.084 \\
Simulation 6 & 12.6 & 0.34 & 4.0 & 0.084 \\
Simulation 7 & 12.6 & 0.34 & 3.0 & 0.126 \\
Simulation 8 & 12.6 & 0.34 & 3.0 & 0.042 \\
\hline
\end{tabular}

\subsection{Results}

Steady-state saturation plots for Experiments I and II are shown in Figures 4.3 and 4.4, respectively. Figure 4.3 indicates the majority of the injected water from the top migrates through the contaminated zone. As a result of capillary action, water saturations generally decrease from left to right. For Experiment II, the water saturation distribution is largely affected by the silt layer. Saturations in this layer are $>0.9$. Downward movement below the silt layer is much more uniform than in the comparable zone in Experiment I. The infiltration patterns are consistent with the numerical simulation for the fieldscale simulations.

Measured and simulated Br effluent concentrations are shown in Figure 4.5. As expected, the arrival time for Experiment I was sooner than for Experiment II as the silt layer in Experiment II reduced the water flux through the contaminated zone. Predicted and simulated arrival times and peak concentrations 
are in reasonable agreement. The agreement indicates that solute transport of a conservative tracer can be simulated accurately as long as independently determined values are obtained for hydraulic and porous medium properties. For the duration of the experiments ( 5 days), no phosphate was detected in the effluent samples, as expected.

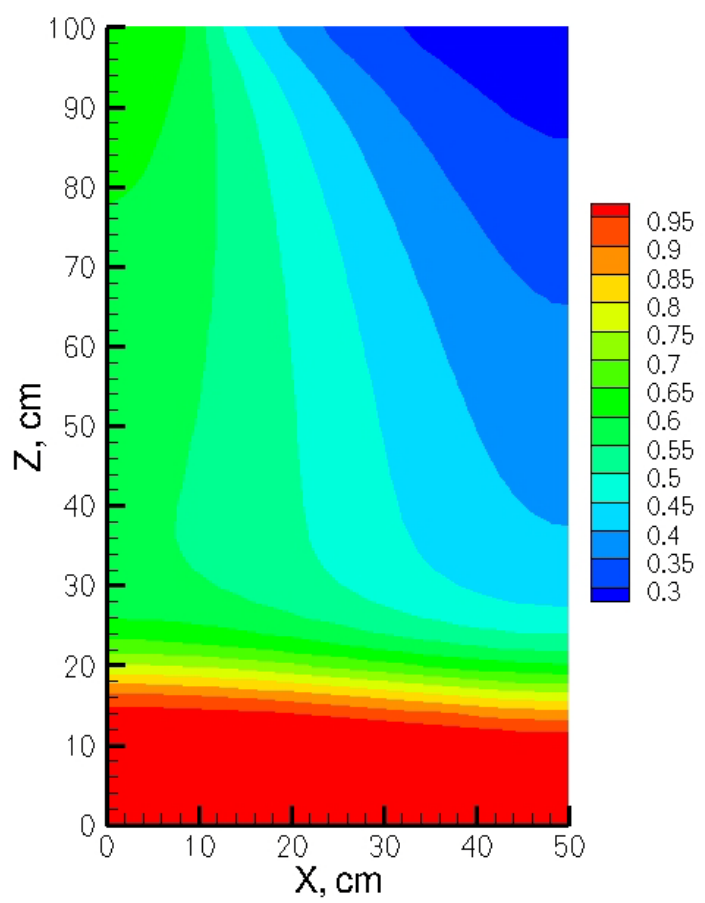

Figure 4.3. Steady-state aqueous saturation distribution for Experiment I based on dual-energy gamma radiation measurements

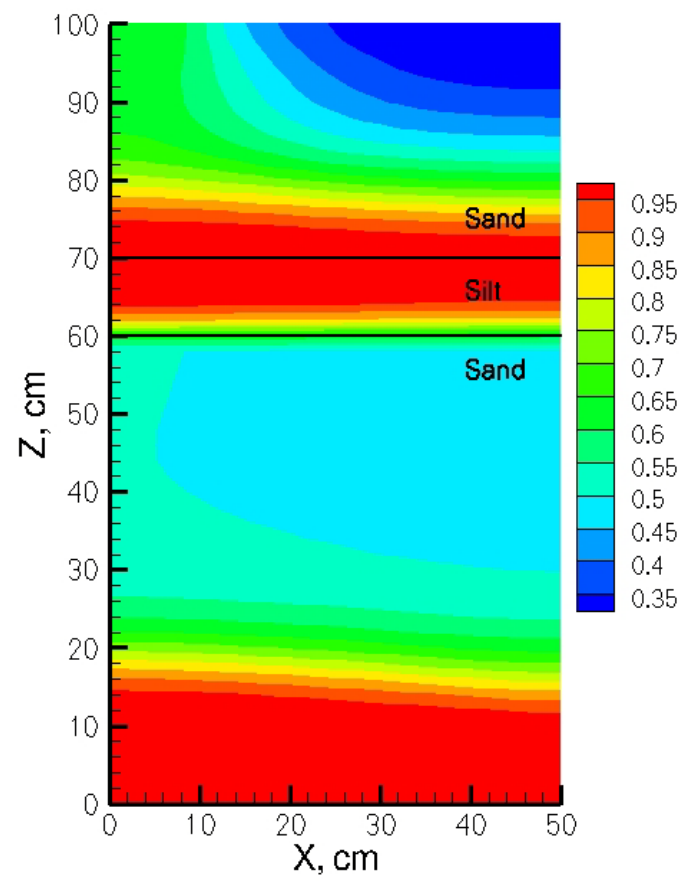

Figure 4.4. Steady-state aqueous saturation distribution for Experiment II based on dual-energy gamma radiation measurements 


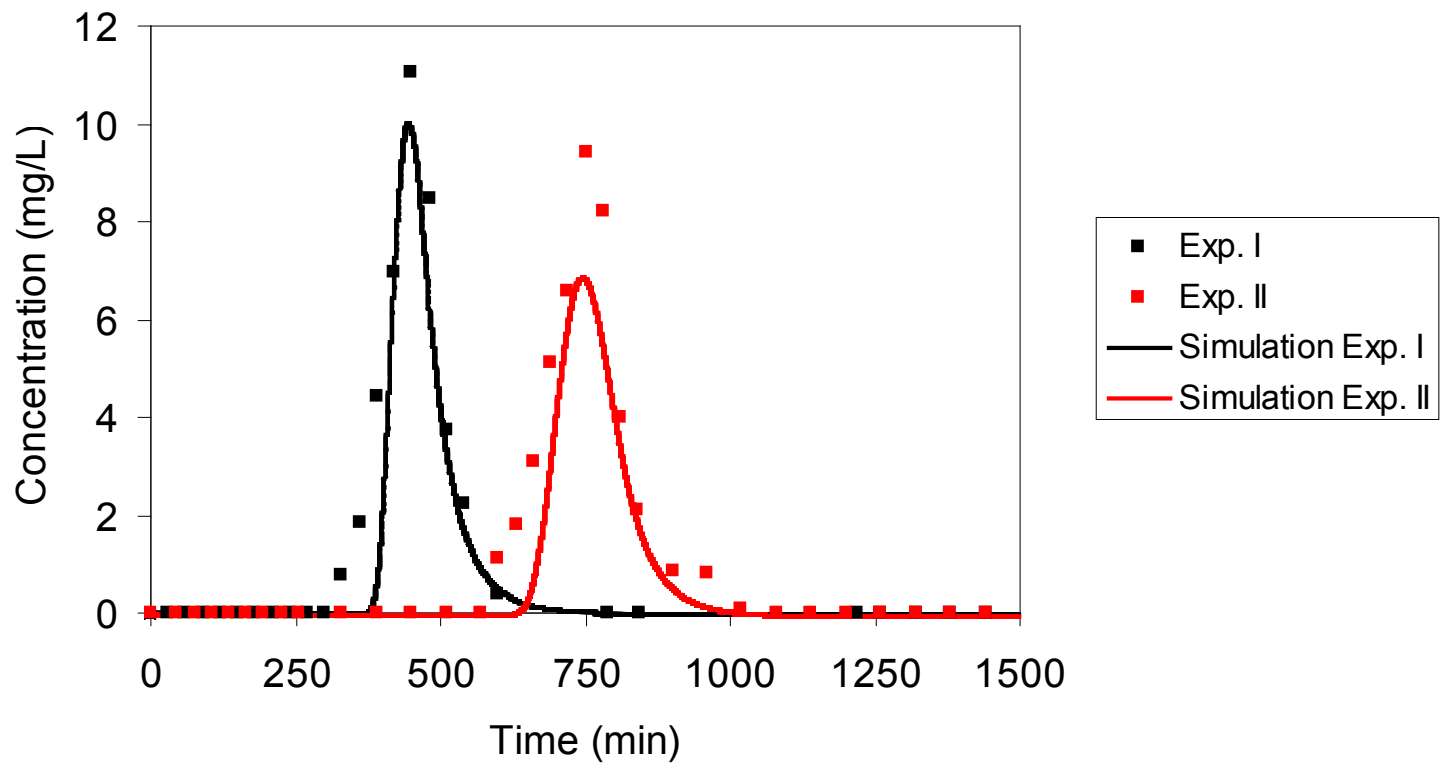

Figure 4.5. Experimental and numerical effluent $\mathrm{Br}$ breakthrough curves for Experiment I and Experiment II

The breakthrough curves for the base case and simulations 1-8 are shown in Figure 4.6. The results are consistent with the imposed input variable change. The tracer arrives sooner when the hydraulic conductivity is increased (Simulation 1) and later when it is decreased (Simulation 2), compared to the base case. An increased porosity (Simulation 3 ) results in a later arrival time while a reduction in porosity (Simulation 4) leads to the opposite result. When the van Genuchten $n$ value is lowered (Simulation 5), water spreads out more due to capillarity, and as a result, the arrival time is later. When the Van Genuchten $\mathrm{n}$ is increased (Simulation 6), water moves more vertically and tracer arrives sooner. An increase in the van Genuchten alpha value (Simulation 7) reduces the highly saturated region above the water table and less mixing occurs with the horizontally injected water. As a result, the tracer arrives sooner at the effluent sampling port. The opposite occurs for the simulation with a smaller alpha (Simulation 8), as this change will lead to an extended zone with higher saturation.

The simulated downward motion of the $\mathrm{Br}$ tracer in Experiment $\mathrm{I}$ is shown at $\mathrm{t}=1,3$, and 6 hours in Figures 4.7, 4.8, and 4.9, respectively. After 1 hour of flushing, the injected water has just reached the contaminated zone. After 3 hours, the plume has migrated at least $20 \mathrm{~cm}$ in the unsaturated zone, while the peak concentration decreased by a factor of four. After 6 hours, the heavily diluted plume has arrived in the saturated zone.

Concentration distribution plots for Experiment II are shown at $\mathrm{t}=1,3,6$, and 10 hours in Figures 4.10, 4.11, 4.12, and 4.13, respectively. For this experiment, the vertical transport is considerably smaller than for Experiment I. The arrival time in the saturated zone is close to 10 hours, which is almost double what was observed for Experiment I. 


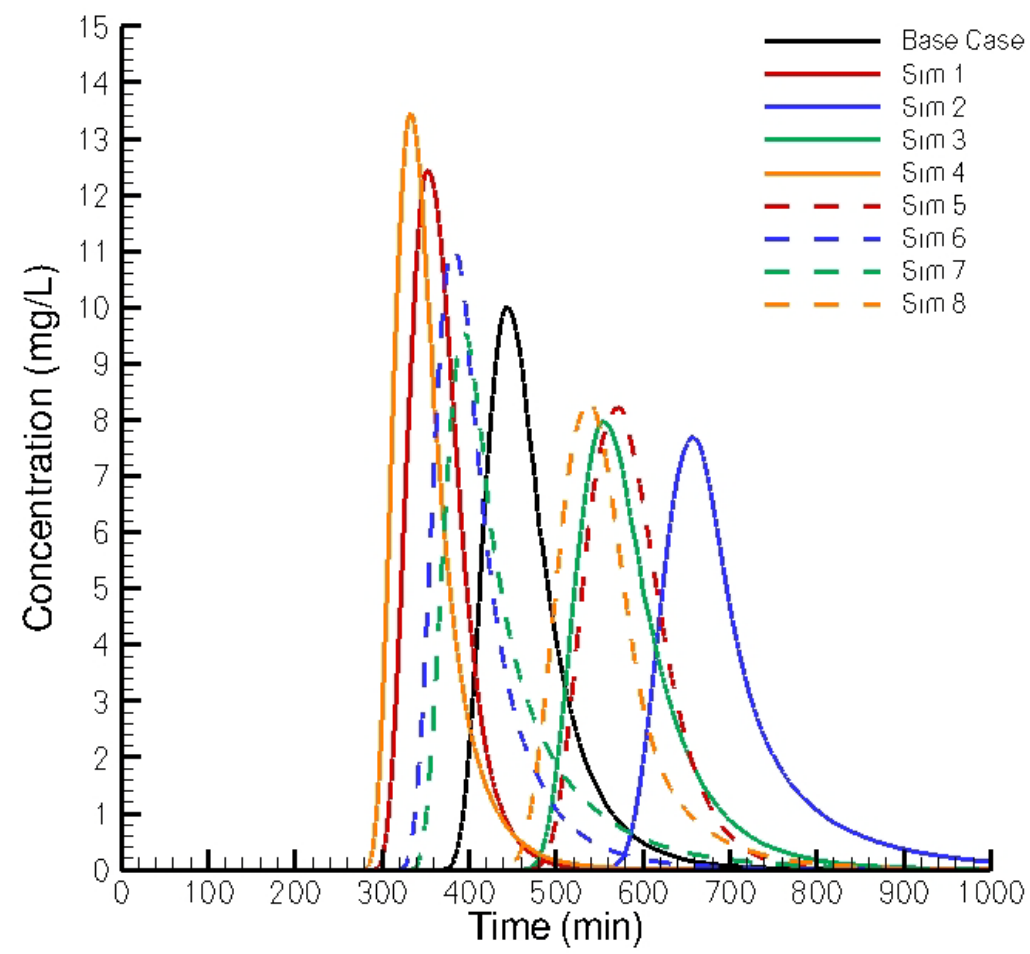

Figure 4.6. Simulated $\mathrm{Br}$ effluent breakthrough curves for the base case and Simulations 1-8 for the homogeneous configuration

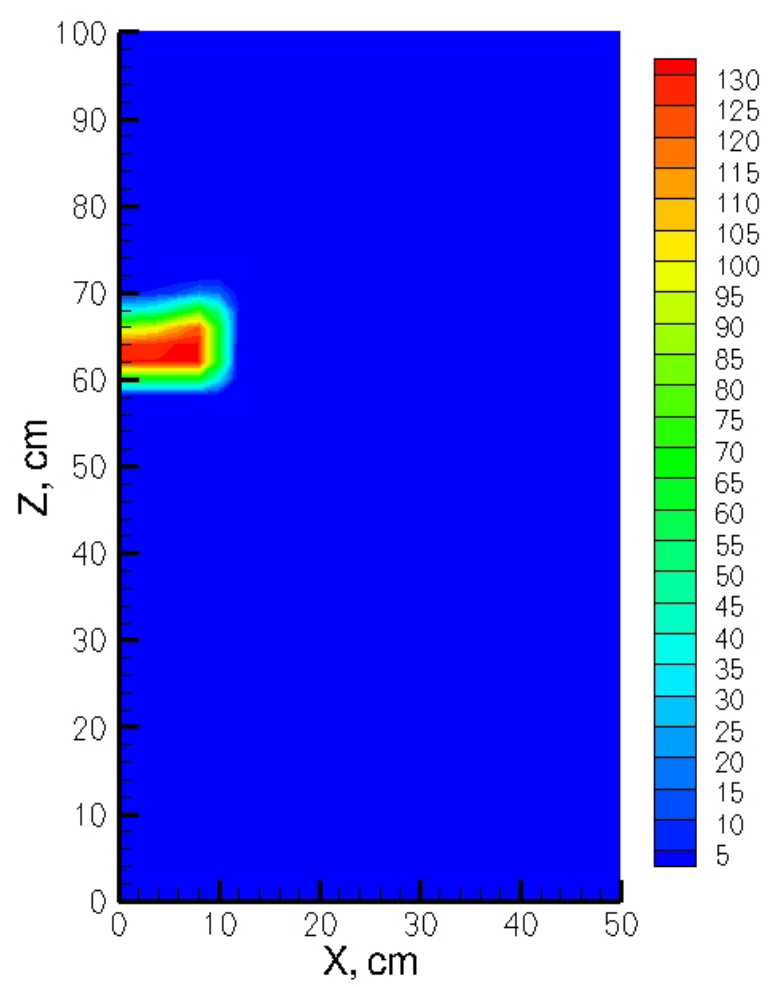

Figure 4.7. Simulated $\mathrm{Br}$ concentration distribution $(\mathrm{mg} / \mathrm{L})$ after 1 hour of flushing for Experiment I 


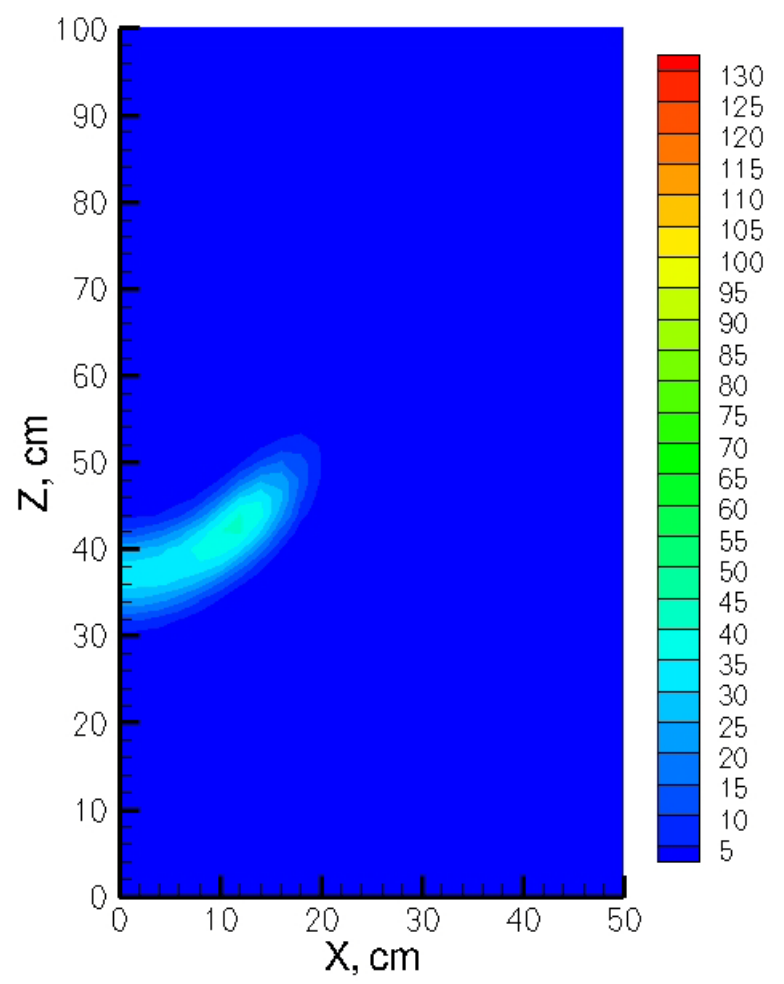

Figure 4.8. Simulated $\mathrm{Br}$ concentration distribution $(\mathrm{mg} / \mathrm{L})$ after 3 hours of flushing for Experiment I

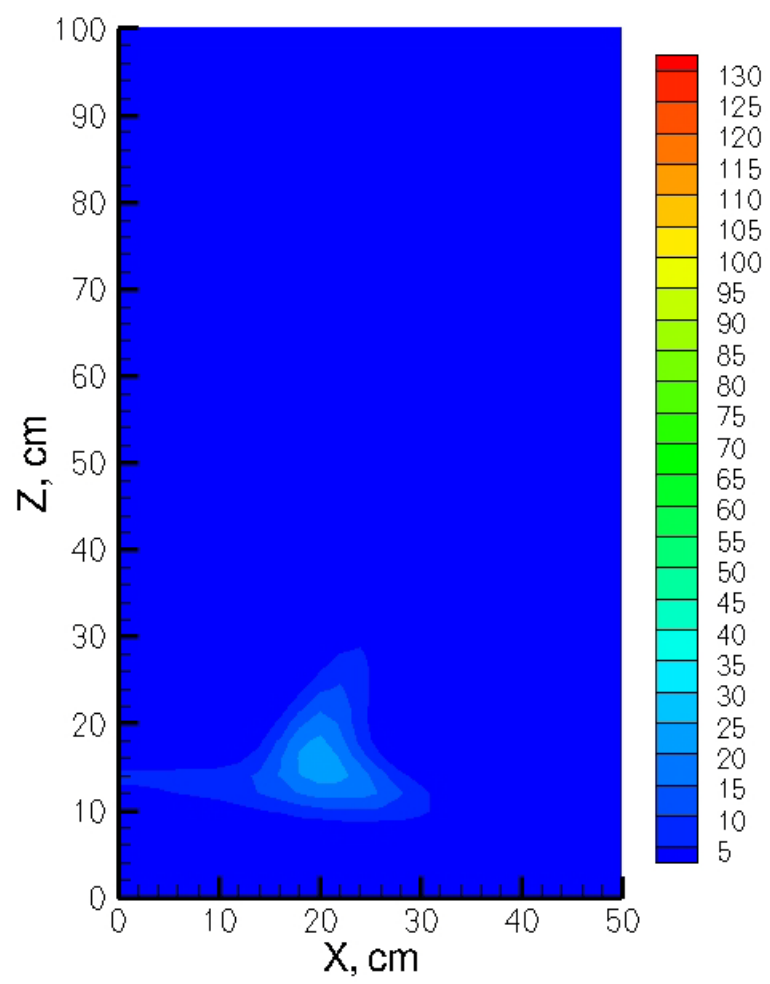

Figure 4.9. Simulated $\mathrm{Br}$ concentration distribution $(\mathrm{mg} / \mathrm{L})$ after 6 hours of flushing for Experiment I 


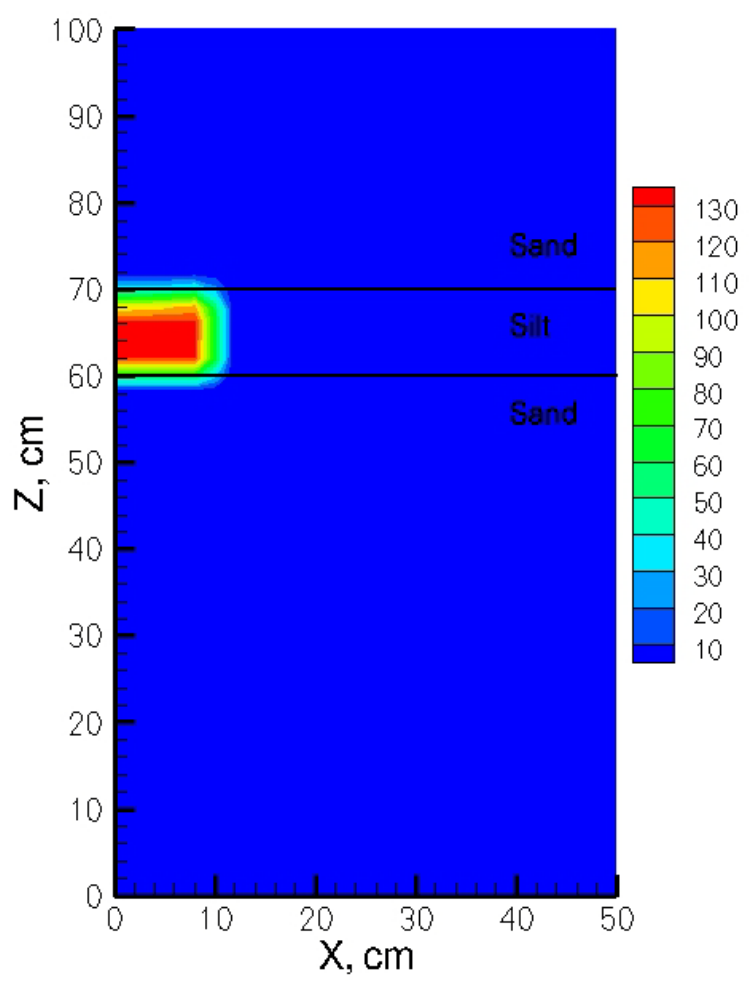

Figure 4.10. Simulated $\mathrm{Br}$ concentration distribution $(\mathrm{mg} / \mathrm{L})$ after 1 hour of flushing for Experiment II

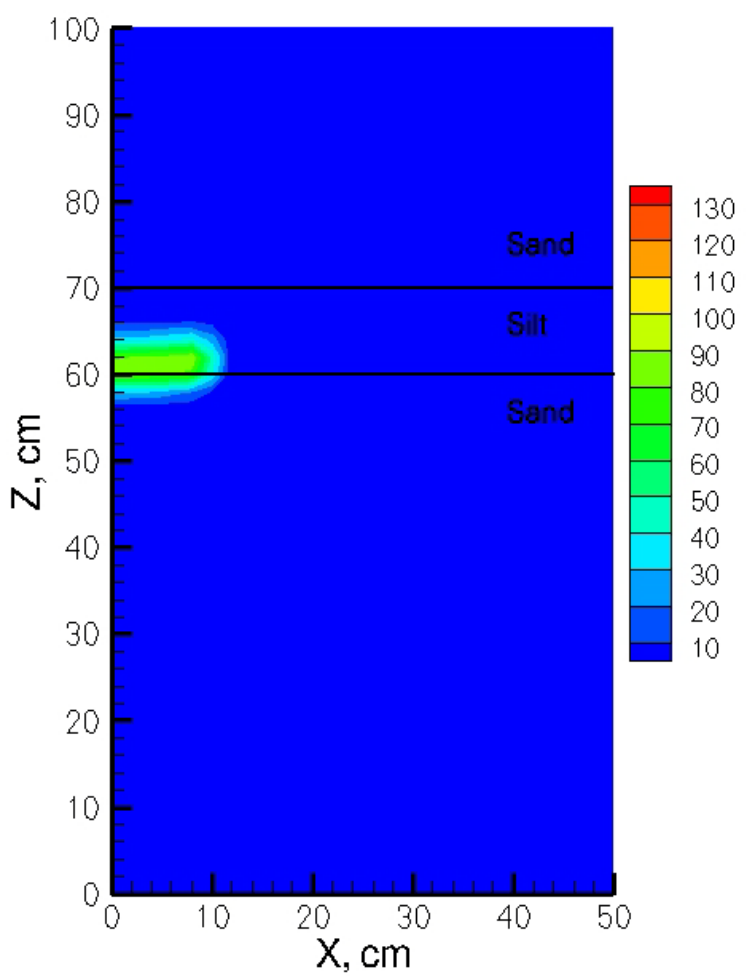

Figure 4.11. Simulated $\mathrm{Br}$ concentration distribution $(\mathrm{mg} / \mathrm{L})$ after 3 hours of flushing for Experiment II 


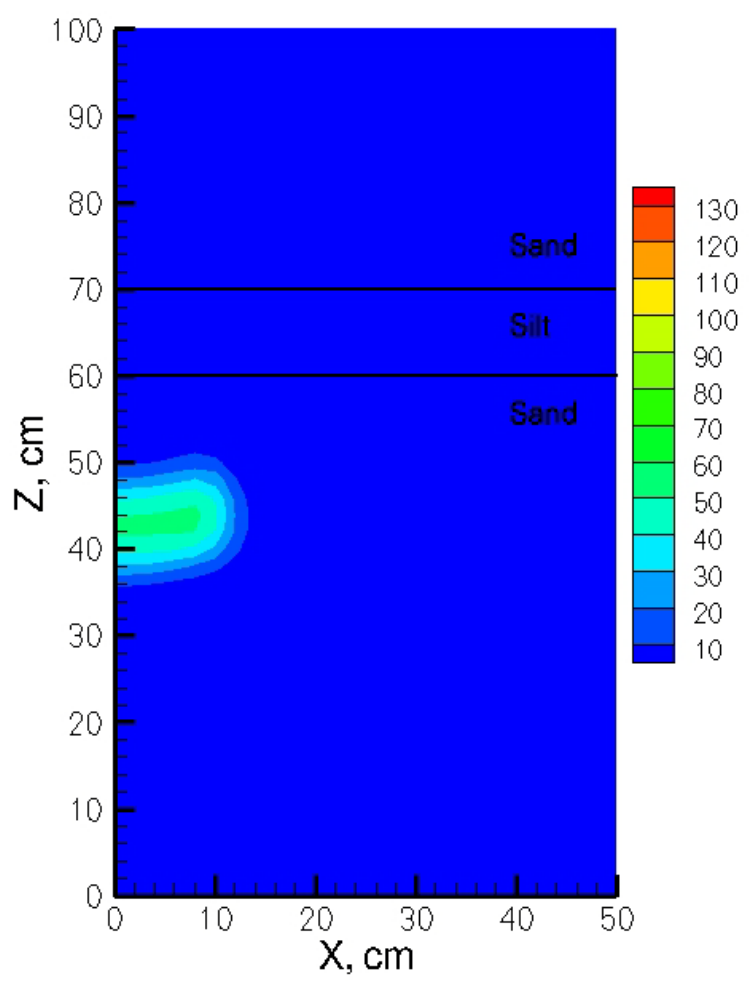

Figure 4.12. Simulated $\mathrm{Br}$ concentration distribution $(\mathrm{mg} / \mathrm{L})$ after 6 hours of flushing for Experiment II

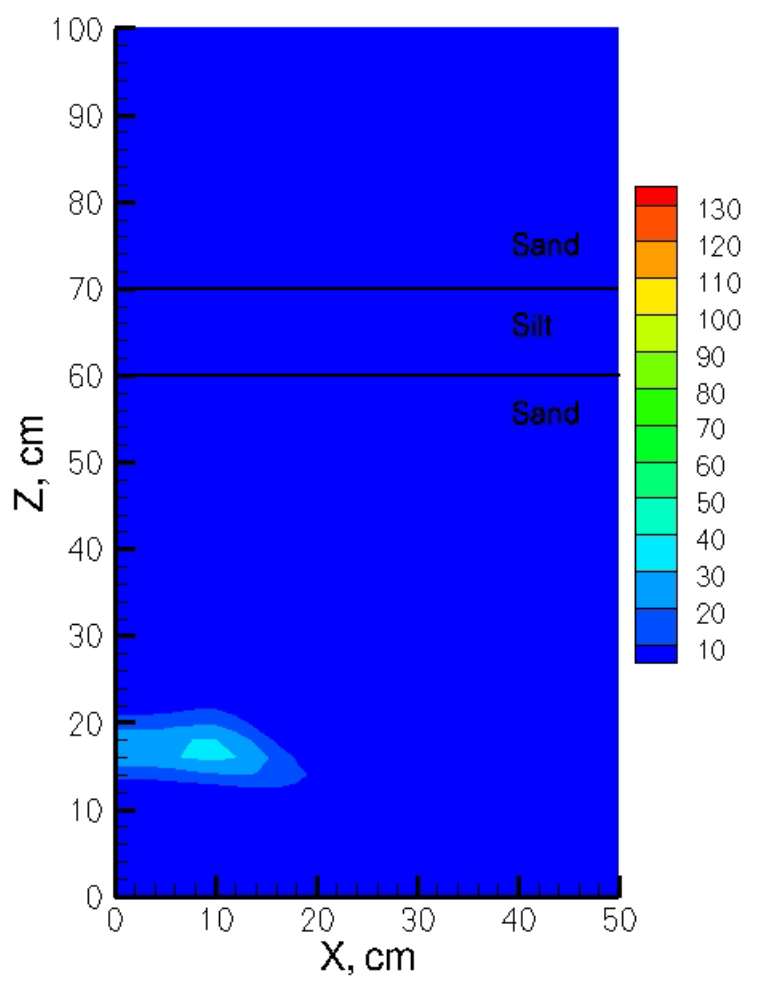

Figure 4.13. Bromide concentration distribution $(\mathrm{mg} / \mathrm{L})$ after 10 hours of flushing for Experiment II 


\subsection{Related Studies}

Infiltration studies are being conducted as part of technology evaluation activities at the Hanford Site and will provide information relevant to evaluating soil flushing in the Hanford Central Plateau. Efforts are underway at the 300-FF-5 Operable Unit to test infiltration of phosphate solutions for treatment of uranium contamination (e.g., DOE-RL 2009). Infiltration is also being tested as a means to install an apatite barrier in the 100-NR-2 Operable Unit (e.g., DOE-RL 2005). Reports describing these activities are expected to be available over the next few years. 


\subsection{Conclusions}

Soil flushing was included in the Deep Vadose Zone Treatability Test Plan for the Hanford Central Plateau (DOE-RL 2008) as a technology with the potential to remove contaminants from the vadose zone. Soil flushing operates through the addition of water, and if necessary an appropriate mobilizing agent, to mobilize contaminants and flush them from the vadose zone and into the groundwater where they are subsequently captured by a pump-and-treat system (CHG 2007). However, there are uncertainties associated with applying soil flushing to contaminants in the deep vadose zone at the Hanford Central Plateau. The modeling and laboratory efforts reported herein are intended to provide a quantitative assessment of factors that impact water infiltration and contaminant flushing through the vadose zone and into the underlying groundwater. Once in the groundwater, capture of the contaminants would be necessary, but this aspect of implementing soil flushing was not evaluated in this study. Soil flushing was evaluated primarily with respect to applications for technetium and uranium contaminants in the deep vadose zone of the Hanford Central Plateau.

Contaminants such as technetium do not interact significantly with the subsurface sediments and move with the infiltrating water. As such, soil flushing for technetium does not have limitations related to the chemistry of the flushing solution. Conversely, uranium interacts strongly with the subsurface sediments and both sorption and solubility-related processes can significantly slow its movement relative to the infiltrating water. Leaching solutions have been used for uranium extraction, but have limited applicability for sites with uranium contamination in the vadose zone at the Hanford Site for the following reasons.

1. Many applications of leaching — as designed and used for mining purposes — are for removing reduced-phase uranium where oxidation of the subsurface dissolves precipitated uranium and makes it readily available for transport to a collection area. The bulk of the uranium is not deposited as reduced uranium precipitates in the Hanford Site vadose zone.

2. Many of the leaching processes are mild extraction solutions that are primarily designed to address uranium that is already in relatively mobile forms. As shown in Szecsody et al. (2010a, 2010b), much of the uranium in the Hanford Site vadose zone is present in forms that require a harsh extraction solution to render them mobile. Thus, use of mild extraction solutions would need to be evaluated in terms of whether these solutions can remove a sufficient fraction of the total uranium to meet remediation goals.

3. The harshest leaching solution used for mining, acid dissolution, is not appropriate for use in the thick, high-carbonate vadose zone at the Hanford Site because of its acid neutralization capacity of the sediment and potential co-contaminant releases.

As mentioned above, the potential feasibility of soil flushing applications for environmental remediation has limitations. However, based on the review of prior investigations, carbonate and citric acid flushing solutions may be suitable for extracting the currently mobile fractions of the uranium (i.e., adsorbed and dissolved uranium in the pore water). Removal of the mobile fraction of uranium may be a sufficient to meet remediation goals. The most mobile fraction poses the highest risk to groundwater, and there is a possibility that the rate of release for the more refractory phases may be slow enough to be protective of the groundwater system. 
In addition to the leaching characteristics of the solution used for soil flushing, the processes of water infiltration and associated contaminant flushing need to be considered. Numerical modeling and laboratory flow-cell experiments were conducted to investigate the characteristics of water flow and solute transport through the vadose zone as a function of the imposed infiltration condition, subsurface properties, and the physical properties of the leaching solution (e.g., density and viscosity). Infiltrated water moves vertically in the vadose zone until a layer with a contrasting hydraulic properties is encountered. At these contacts, infiltrated water can be diverted laterally to an extent that depends on the hydraulic properties. Low permeability silt zones are of most significance for inducing lateral water flow in the Hanford Site vadose zone when they are surrounded by higher conductivity material.

Numerical simulations were conducted to quantify the amount of lateral water movement as a function of the thickness and permeability of subsurface silt layers. A key feature of the vadose zone is the $\mathrm{CCU}$, which in many locations, is a relatively thick, low-permeability silt layer. Silt layers, though not as large, are also distributed in other portions of the Hanford Site vadose zone. As expected, lateral flow increased with decreased hydraulic conductivity and increased thickness of a silt layer. In portions of the 200 West Area with a relatively thick low-permeability CCU, or if a thick silt zone were present in the 200 East Area, significant lateral water movement would be expected. For a specific site, the thickness and permeability of silt layers/lenses should be considered with respect to these simulation results to determine the expected extent of lateral water movement during soil flushing. While lateral water movement was most significant at silt layers, some lateral water movement occurred at most contacts with a layer of lower permeability overlying a layer of higher permeability. Some lateral water spreading also occurs due to capillary action in the vadose zone. Alteration of the fluid density or viscosity has a minor impact on movement of the flushing solution. The surface tension of the infiltrating fluid could also be varied to help maintain more vertical infiltration, but was not evaluated in the current study.

The impact of lateral water movement could be beneficial in terms of increasing the swept zone of the infiltration water. However, lateral flow could also increase the size of the capture zone needed in the groundwater and may cause water to be diverted towards areas with preferential downward flow that bypass contaminants. Lateral water flow also could increase the time and total water volume needed for soil flushing at a specific site.

The impact of lateral water movement on contaminants depends on the location of the contaminants relative to the infiltration area and subsurface layering. Lateral contaminant movement was limited for the imposed contaminant zones in the model even in cases with significant lateral water movement. The contaminant zones in the model were located vertically beneath the infiltration area at the surface. Simulation results show that contaminant transport was primarily downward even when there was significant overall lateral movement of the infiltrated water. For the simulations, the contaminated zones were located within or adjacent to the CCU for the 200 West Area and imposed silt layers for the 200 East Area. Contaminants distributed elsewhere may experience some lateral movement, but this situation was not quantified in the simulations.

The simulations used laterally continuous layering. Thus, the impact of lateral heterogeneity, such as the presence of discontinuous silt lenses, was not quantified. Preferential pathways for water movement either caused by discontinuities in subsurface properties, or features such as clastic dikes, were not evaluated but should be considered for a specific site. Presence of preferential pathways could limit the effectiveness of flushing if contaminated zones are bypassed. The model also did not evaluate any slope 
to layers or inherent layer anisotropy that could impose lateral flow. These types of uncertainties may need to be considered in the design of a soil flushing system for a specific site, including design of a groundwater capture system in terms of the necessary capture zone. Limitations to infiltration at the surface may be another uncertainty to consider that was not included in the simulations. Presence of features that cause ponding of water rather than infiltration may limit soil flushing effectiveness. Surface infiltration rates for a specific site may need to be quantified as part of evaluating the applicability of soil flushing. The current field testing in the 300-FF-5 and 100-NR-2 Operable Units should provide some information relevant to surface infiltration rates. 


\subsection{References}

Adin A, P Klotz, and P Newman. 1970. "Mixed-Metal Complexes Between Indium(III) and Uranium(VI) with Malic, Citric, and Tartaric Acids.” Inorg. Chem. 9:2499-2505.

Armiran M and C Wilde. 1992. "Remediation of Contaminated Soil Using Biogenesis ${ }^{\circledR}$ Soil Washing," pp 13, in Abstract Proceedings: Fourth Forum on Innovative Hazardous Waste Treatment Technologies: Domestic and International, San Francisco, CA, November 17-19, 1992. EPA/540/R-92/081, Office of Solid Waste and Emergency Response, U.S. Environmental Protection Agency, Washington, D.C.

Bartlett RW. 1998. Solution Mining: Leaching and Fluid Recovery of Materials. 2nd Ed., Gordon and Breach Science Publishers, Amsterdam, Netherlands, 443 pp.

Beckett PHT. 1989. "The Use of Extractants in Studies on Trace Metals in Soils, Sewage Sludges, and Sludge-Treated Soils." Adv. Soil Sci. 9:143-176.

Binder B. 1971. "Mixed-Valence Complexes of Iron(III) With Iron(II) and Mixed-Metal Complexes of Iron(III) With Tin(II) in Aqueous Citrate Media.” Inorg. Chem. 10:2146-2150.

Brendler V, G Geipel, G Bernhard, and H Nitsche. 1995. "Possible Impacts of Phosphate Influx on the Uranium Speciation and Migration in Seepage Waters." In B Merkel, S Hurst, EP Löhnert, and W Struckmeier (Eds.), Proceedings of the International Conference Workshop on Uranium Mining and Hydrogeology, October 1995, Freiberg, Germany, October 1995, Verlag Sven v. Loga, Köln, p. 61.

CHG. 2007. Central Plateau Vadose Zone Remediation Technology Screening Evaluation. CH2M HILL Hanford Group, Richland, Washington.

COGEMA Mining Inc. 2004. Wellfield Restoration Report, Irigaray Mine. Submitted to the Wyoming Department of Environmental Quality, June 2004.

Crow Butte Resources Inc. 2000. Mine Unit 1 Restoration Report, Crow Butte Uranium Project. Submitted to the U.S. Nuclear Regulatory Commission Office of Nuclear Material Safety and Safeguards, January 10, 2000.

Deutsch WJ, WJ Martin, LE Eary, and RJ Serne. 1985. Methods of Minimizing Ground-Water Contamination from In Situ Leach Uranium Mining: Final Report. PNL-5319, U.S. Nuclear Regulatory Commission (Ed.), Washington D.C.

Dodge CJ and AJ Francis. 1997. "Biotransformation of Binary and Ternary Citric Acid Complexes of Iron and Uranium." Environ. Sci. Technol. 31:3062-3067.

Dodge CJ and AJ Francis. 2003. "Structural Characterization of a Ternary Fe(III)-U(VI)-Citrate Complex." Radiochim. Acta. 91:525-532.

DOE-RL. 2005. Strontium-90 Treatability Test Plan for 100-NR-2 Groundwater Operable Unit. DOE/RL-2005-96, Draft A, U.S. Department of Energy, Richland Operations Office, Richland, Washington. 
DOE-RL. 2008. Deep Vadose Zone Treatability Test Plan for the Hanford Central Plateau. DOE/RL-2007-56, Rev. 0, U.S. Department of Energy, Richland Operations Office, Richland, Washington.

DOE-RL. 2009. 300-FF-5 Groundwater Operable Unit Infiltration Test Sampling and Analysis Plan. DOE/RL-2009-16, Rev. 0, U.S. Department of Energy, Richland Operations Office, Richland, Washington.

Dong W and SC Brooks. 2006. "Determination of the Formation Constants of Ternary Complexes of Uranyl and Carbonate with Alkaline Earth Metals $\left(\mathrm{Mg}^{2+}, \mathrm{Ca}^{2+}, \mathrm{Sr}^{2+}\right.$, and $\left.\mathrm{Ba}^{2+}\right)$ Using Anion Exchange Method." Environ. Sci. Technol. 40:4689-4695.

Duff MC, CFV Mason, and DB Hunter. 1998. "Comparison of Acid and Base Leach for the Removal of Uranium from Contaminated Soil and Catch-Box Media.” Canadian Journal of Soil Science 78:675-683.

Fjeld RA, JT Coates, and AW Elzerman. 2000. Final Column Tests to Study the Transport of Plutonium and Other Radionuclides in Sedimentary lnterbed at INEEL. INEEUEXT-01-00763, Rev. 0, Idaho National Engineering and Environmental Laboratory, Bechtel BWXT Idaho, LLC, Idaho Falls.

Francis CW, AJ Mattus, LL Farr, MP Elless, and SY Lee. 1993. Selective Leaching of Uranium from Uranium-Contaminated Soils: Progress Report 1. ORNL/TM-12177, Oak Ridge National Laboratory, Oak Ridge, Tennessee.

Gadelle F, J Wan, and TK Tokunaga. 2001. "Removal of Uranium(VI) from Contaminated Sediments by Surfactants." J. Environ. Qual. 30:470-478.

Gupta DC and H Singh. 2005. "Uranium Resource Processing: Secondary Resources, Developments in Uranium Resources, Production, Demand and the Environment." In Proceedings of a Technical Committee Meeting Held in Vienna, June 15-18, 1999, IAEA-TECDOC-1425, International Atomic Energy Agency, Vienna, Austria.

Huang FY, PV Brady, ER Lindgren, and P Guerra. 1998. "Biodegradation of Uranium-Citrate Complexes: Implications for Extraction of Uranium from Soils.” Environ. Sci. Technol. 32:379-382.

Jackson ML. 1985. Soil Chemical Analysis-Advanced Course. 2nd ed., University of Wisconsin, Madison, Wisconsin.

Jackson ML, CH Lim, and LW Zelazny. 1986. "Oxides, Hydroxides, and Aluminosilicates," pp. 101-150, in A Klute (ed.), Methods of Soil Analysis. Part 1, 2nd ed. Agron. Monogr. 9. SSSA, Madison, Wisconsin.

Jeuken B, H Märten, and R Phillips. 2008. "Uranium ISL Operation and Water Management under the Arid Climate Conditions at Beverley, Australia." The $10^{\text {th }}$ International Mine Water Association Congress, Karlsbad, Czech Republic, June 2-5, 2008.

Kantar C and BD Honeyman. 2006. "Citric Acid Enhanced Remediation of Soils Contaminated with Uranium by Soil Flushing and Soil Washing." Journal of Environmental Engineering 132(2):247-255. 
Kantar C, JB Gillow, R Harper-Arabie, BD Honeyman, and AJ Francis. 2005. "Determination of Stability Constants of U(VI)-Fe(III)-Citrate Complexes.” Environ. Sci. Technol. 39:2161-2168.

Kulpa JP and JE Hughes. 2001. "Deployment of Chemical Extraction Soil Treatment on Uranium Contaminated Soil." In WM'01 Conference, February 25-March 1, 2001, Tucson, AZ, 2001. Available at http://www.wmsym. org/Abstracts/2001/54/54-5.pdf.

Langmuir D. 1978. "Uranium Solution-Mineral Equilibria at Low Temperature with Applications to Sedimentary Ore-Deposits." Geochim. Cosmochim. Acta 42:547-569.

Last GV, RD Mackley, and DC Lanigan. 2006. Borehole Geologic Data for the 216-Z Crib Facilities A Status of Data Assembled through the Hanford Borehole Geologic Information System (HBGIS).

PNNL-16103, Pacific Northwest National Laboratory, Richland, Washington.

Last GV, PD Thorne, JA Horner, KR Parker, BN Bjornstad, DC Lanigan and BA Williams. 2009a. Hydrogeology of the Hanford Site Central Plateau - A Status Report for the 200 West Area. PNNL-17913, Rev. 1, Pacific Northwest National Laboratory, Richland, Washington.

Last GV, M Rockhold, C Murray, and K Cantrell. 2009b. Selection and Traceability of Parameters to Support Hanford-Specific RESRAD Analyses. PNNL-18564, Pacific Northwest National Laboratory, Richland, Washington.

Lindsey KA, SE Kos, and KD Reynolds. 2000. Vadose Zone Geology of Boreholes 299-W22-50 and 299-W23-19 S-SX Waste Management Area Hanford Site, South-Central Washington. RPP-6149, Rev. 0, Richland, Washington.

Manzurola E, A Apelblat, G Markovits, and O Levy. 1989. "Mixed-Metal Hydroxycarboxylic Acid Complexes." J. Chem. Soc., Faraday Trans. 85:373-379.

Markovits G, P Klotz, and L Newman. 1972. "Formation Constants for the Mixed-Metal Complexes Between Indium(III) and Uranium-(VI) with Malic, Citric, and Tartaric Acids.” Inorg. Chem. 11:2405-2408.

Mason CF, WR Turney, BM Thomson, N Lu, PA Longmire, and CJ Chisholm-Brause. 1997. "Carbonate Leaching of U from Contaminated Soils.” Environ. Sci. Technol. 31:2707-2711.

McKinley JP, JM Zachara, J Wan, DE McCready, and SM Heald. 2007. "Geochemical Controls on Contaminant Uranium in Vadose Hanford Formation Sediments at the 200 Area and 300 Area, Hanford Site, Washington." Vadose Zone J. 6:1004-1017. DOI:10.2136/vzj2006.0184.

Merritt RC. 1971. "The Extractive Metallurgy of Uranium.” Colorado School of Mines Research, Golden, Colorado.

Mudd G. 2000a. "Acid In Situ Leach Uranium Mining: 1 - USA and Australia." Tailings and Mine Waste '00, Fort Collins, CO, USA, January 23-26, 2000. Available at http://www.seaus.org.au/pdfs/tmw00/TMW00-Oz-USA.pdf. 
Mudd G. 2000b. “Acid In Situ Leach Uranium Mining: 2 - Soviet Block and Asia." Tailings and Mine Waste '00, Fort Collins, CO, USA, January 23-26, 2000. Available at http://www.seaus.org.au/pdfs/tmw00/TMW00-FSU-Asia.pdf.

NRC (U.S. Nuclear Regulatory Commission). 2009. Generic Environmental Impact Statement for In-Situ Leach Uranium Milling Facilities. NUREG-1910, Vol. 1. Chapters 1-4, Final Report, U.S. Nuclear Regulatory Commission, Office of Federal and State Materials and Environmental Management Programs and Wyoming Department of Environmental Quality Land Quality Division.

NRC (U.S. Nuclear Regulatory Commission). 2010. In Situ Recovery Facilities. Accessed August 30, 2010, at www.nrc.gov/materials/uranium-recovery/extraction-methods/isl-recovery-facilities.html.

Oostrom M, PD Thorne, ZF Zhang, GV Last, and MJ Truex. 2008. Modeling of Carbon Tetrachloride Flow and Transport in the Subsurface of the 200 West Disposal Sites: Large-Scale Model Configuration and Prediction of Future Carbon Tetrachloride Distribution Beneath the 216-Z-9 Disposal Site. PNNL-17181, Pacific Northwest National Laboratory, Richland, Washington.

Oostrom M, C Hofstee, JH Dane, and RJ Lenhard. 1998. "Single-Source Gamma Radiation for Improved Calibration and Measurements in Porous Media Systems." Soil Science 163:646-656.

Oostrom M, ML Rockhold, PD Thorne, GV Last, and MJ Truex. 2004. Three-Dimensional Modeling of DNAPL in the Subsurface of the 216-Z-9 Trench at the Hanford Site. PNNL-14895, Pacific Northwest National Laboratory, Richland, Washington.

ORNL. 1993. Removal of Uranium from Uranium-Contaminated Soils: Phase I: Bench-Scale Testing. ORNL-6762, Oak Ridge National Laboratory, Oak Ridge, Tennessee.

Pabalan RT and DR Turne. 1997. "Uranium (6+) Sorption on Montmorillonite: Experimental and Surface Complexation Modeling Study." Aquat. Geochem. 2:203-226.

Pabalan RT, DR Turner, FP Nertetti, JD Prikryl. 1998. "Uranium(VI) Sorption Onto Selected Mineral Surfaces, Key Geochemical Parameters.” In EA Jenne (Ed.), Adsorption of Metals, Geomedia, Academic Press, San Diego, California.

Pelizza MS. 2008. “In-Situ Recovery of Uranium.” Southwest Hydrology 7:28-29.

Phillips EJP, ER Landa, and DR Lovley. 1995. "Remediation of Uranium Contaminated Soils with Bicarbonate Extraction and Microbial U(VI) Reduction.” J. Ind. Microbiol. 14:203-207.

Power Resources, Inc. 1999. Ground Water Restoration Report, A-Wellfield, Highland Uranium Project. Submitted to Wyoming Department of Environmental Quality Land Quality Division, April 23, 1999.

Rajan KS and AE Martell. 1965. "Equilibrium Studies of Uranyl Complexes III. Interaction of Uranyl Ion with Citric Acid." Inorg. Chem. 4:462-469.

Schramke JA, H Demuth, and MS Pelizza. 2009. "Geochemistry of Uranium In-Situ Leach Aquifers After Restoration.” Presented at U2009 Global Uranium Symposium, Keystone, Colorado, May 2009. 
Stewart CL. 2002. "The Mineralogy of Uranium Rollfront Deposits and Its Significance to In-Situ Carbonate Leach Mining.” M.S. Thesis, Department of Geology and Geophysics, University of Wyoming, Laramie, Wyoming.

Szecsody JE, MJ Truex, L Zhong, MD Williams, CT Resch, and JP McKinley. 2010a. Remediation of Uranium in the Hanford Vadose Zone Using Gas-Transported Reactants: Laboratory Scale Experiments. PNNL-18879, Pacific Northwest National Laboratory, Richland, Washington.

Szecsody, JE, MJ Truex, L Zhong, NP Qafoku, MD Williams, JP McKinley, CT Resch, JL Phillips, D Faurie, and J Bargar. 2010b. Remediation of Uranium in the Hanford Vadose Zone Using Ammonia Gas: FY10 Laboratory-Scale Experiments. PNNL-20004, Pacific Northwest National Laboratory, Richland, Washington.

Taylor G, V Farrington, P Woods, R Ring, and R Molloy. 2004. Review of Environmental Impacts of the Acid In-situ Leach Uranium Mining Process. CSIRO Land and Water Client Report, August 2004, 60 pp.

Um W, Z Wang, RJ Serne, BD Williams, CF Brown, CJ Dodge, and JF Arokiasamy. 2009. "Uranium Phases in Contaminated Sediments Below Hanford's U Tank Farm.” Environmental Science \& Technology 43(12):4280-4286. DOI:10.1021/es900203r.

Wade PW, S Woodbourne, WM Morris, P Vos, and NV Jarvis. 2000. Tier 1 Risk Assessment of Radionuclides in Selected Sediments of the Mooi River. WRC-Project No. K5/1095, Pretoria Water Research Commission, Pretoria, South Africa.

Waite TD, JA Davis, TE Payne, GA Waychunas, and N Xu. 1994. "Uranium(VI) Adsorption to Ferrihydrite: Application of a Surface Complexation Model." Geochim. Cosmochim. Acta 58:5465-5478.

Ward AL, ME Conrad, WD Daily, JB Fink, VL Freedman, GW Gee, GM Hoversten, JM Keller, EL Majer, CJ Murray, MD White, SB Yabusaki, and ZF Zhang. 2006. Vadose Zone Transport Field Study: Summary Report. PNNL-15443, Pacific Northwest National Laboratory, Richland, Washington.

White MD and M Oostrom. 2006. STOMP Subsurface Transport Over Multiple Phases, Version 4.0, User's Guide. PNNL-15782, Pacific Northwest National Laboratory, Richland, Washington.

Wietsma TW, M Oostrom, MA Covert, TW Queen, and MJ Fayer. 2009. “An Automated Apparatus for Constant Flux, Constant Head, and Falling Head Hydraulic Conductivity Measurements." Soil Science Society of America J. 73:466-470.

Winde F. 2002. "Uranium Contamination of Fluvial Systems-Mechanisms and Processes, Part III." Cuadernos de Investigacion Geografica 28:75-100.

Yousfi I, J Bole, and O Geiss. 1999. "Chemical Extractions Applied to the Determination of Radium Speciation in Uranium Mill Tailing: Study of Different Reagents.” J. Radioanal. Nucl. Chem. 240:835-840.

Zachara JM, RJ Serne, M Freshley, F Mann, F Anderson, M Wood, T Jones, and D Myers. 2007a. "Geochemical Processes Controlling Migration of Tank Wastes in Hanford's Vadose Zone." Vadose Zone J. 6:985-1003. DOI:10.2136/vzj2006.0180. 
Zachara JM, CF Brown, JN Christensen, JA Davis, PE Dresel, C Liu, SD Kelly, JP McKinley, RJ Serne, and W Um. 2007b. "A Site Wide Perspective on Uranium Geochemistry at the Hanford Site." PNNL-17031, Pacific Northwest National Laboratory, Richland, Washington.

Zhou P and B Gu. 2005. "Extraction of Oxidized and Reduced Forms of Uranium from Contaminated Soils: Effects of Carbonate Concentration and pH.” Environ. Sci. Technol. 39:4435-4440. 
PNNL-19938

\section{Distribution}

No. of

Copies
No. of

Copies
2 CH2M HILL Plateau Remediation Company

MW Benecke (P/PDF)

GB Chronister (P/PDF)

R3-60

R3-60

JA Schramke

Enchemica, LLC

2335 Buckingham Cir.

Loveland, CO, 80538-53611

(PDF)
1

\section{Local Distribution}

Pacific Northwest National Laboratory

KC Carroll

(PDF)

KA Gordon

GV Last

(PDF)

(PDF)

M Oostrom

ZF Zhang

JA Schramke

GD Tartakovsky

(PDF)

(PDF)

(PDF)

(PDF)

MJ Truex (P/PDF)

K6-96

TW Wietsma 



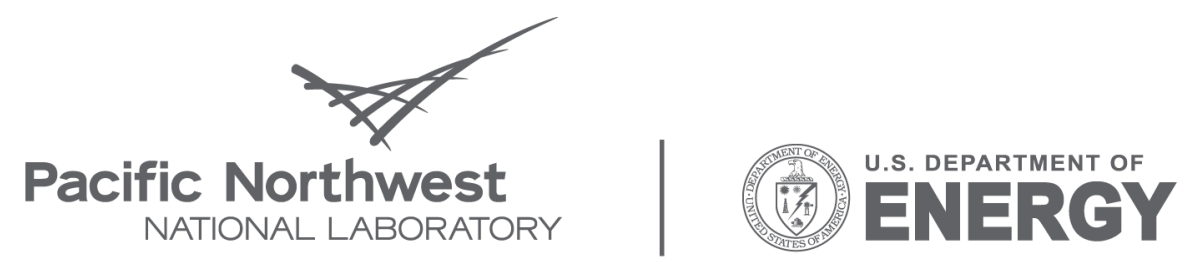

Proudly Operated by Battelle Since 1965

902 Battelle Boulevard

P.O. Box 999

Richland, WA 99352

1-888-375-PNNL (7665)

www.pnl.gov 